\title{
The Nation's Health Care Bill WHO BEARS THE BURDEN?
}

\section{A CHARTBOOK}
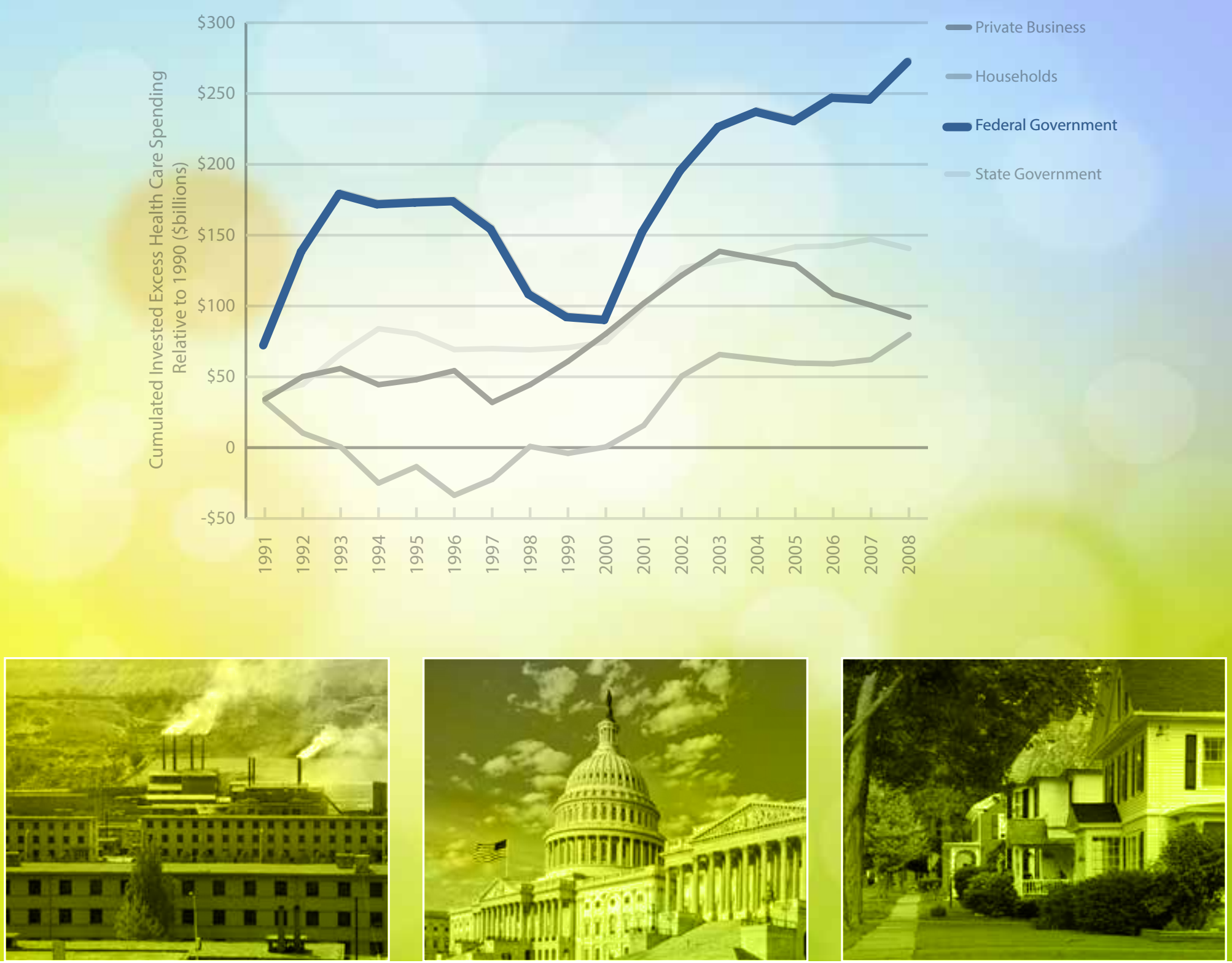


\section{A Chartbook \\ The Nation's Health Care Bill: Who Bears the Burden? \\ Jerry Cromwell, Deborah Healy, Elizabeth Seeley, \\ Diana Trebino, and Genevieve Cromwell}


C 2013 Research Triangle Institute. RTI International is a registered trademark and a trade name of Research Triangle Institute. The RTI logo is a registered trademark of Research Triangle Institute.

(c) (i) $\Theta$ This work is distributed under the terms of a Creative By Nc ND Commons Attribution-NonCommercial-

NoDerivatives 4.0 license (CC BY-NC-ND), a copy of which is available at https://creativecommons.org/licenses/by-nc-nd /4.0/legalcode.

Library of Congress Control Number: 2013943412

ISBN 978-1-934831-12-0

https://doi.org/10.3768/rtipress.2013.bk.0010.1307

www.rti.org/rtipress

The RTI Press mission is to disseminate information about RTI research, analytic tools, and technical expertise to a national and international audience. RTI Press publications are peer-reviewed by at least two independent substantive experts and one or more Press editors.

RTI International is an independent, nonprofit research institute dedicated to improving the human condition. We combine scientific rigor and technical expertise in social and laboratory sciences, engineering, and international development to deliver solutions to the critical needs of clients worldwide.

\section{About the Authors}

Jerry Cromwell, PhD in economics, Harvard University, is an RTI International Senior Fellow in health economics based in RTI's Waltham, Massachusetts, office.

Deborah Healy, $\mathrm{PhD}$, University of Chicago, is a senior economist specializing in antitrust and health care at Compass Lexecon in Chicago.

Elizabeth Seeley, $\mathrm{PhD}$, London School of Economics, is a research consultant and lecturer at the Harvard School of Public Health with a concentration in pharmaceutical reimbursement policy.

Diana Trebino, MPH in health policy and management, Boston University, is an RTI research associate based in RTI's Waltham, Massachusetts, office.

Genevieve Cromwell, BA in economics, Ohio Wesleyan University, is also an RTI research associate based in RTI's Waltham, Massachusetts, office. 


\section{C \\ Contents}

Executive Summary

Introduction

\section{PART I: Introduction: Growth in Health Care Spending}

Key Findings: Growth in Health Care Spending

Chart 1: Trends in National Health Expenditures (NHE) as a Share of Gross Domestic Product (GDP), 1960-2010

Charts 2 and 3: Trends in Health Care Spending and Shares of Health Care Spending, by Source of Funds, 1990-2010

\section{PART II: Business: Financial Burden of Health Care Spending}

Key Findings: Business Financial Burden of Health Care Spending

Chart 4: Trend in Business Health Care Expenditures per Employee, 1990-2008

Chart 5: Trends in Wages and Salaries and the Ratio of Health Benefits to Wages, 1990-2008

Chart 6: Trends in Manufacturing Hourly Total Compensation Costs, by Country, 1990-2008

Chart 7: Employer Health Insurance Cost per Labor Hour, by Major Industry, 2010

Chart 8: Percentage of Firms That Offer Health Insurance, by Firm Size, 2009

Chart 9: Trend in the Percentage of Employees Enrolled in Private Sector Firms That Offer Health Insurance, by Firm Size, 1996-2009

Chart 10: Trends in Employee Premium Cost Sharing, by Firm Size, 1996-2009

Chart 11: Trends in Average Monthly Employee Contributions to Health Insurance, by Coverage Type and Employment Status, 1999-2006
1

3

4

\section{9} Age 65, by Firm Size, 1997-2009

Chart 14: Potential Uses of Excess Business Health Care Spending, \$92 billion in 2008

\section{PART III: Households: Financial Burden of Health Care Spending}

Key Findings: Household Financial Burden of Health Care Spending

Chart 15: Trends in Household Health Care Spending, by Major Category, 1987-2010

Chart 16: Trends in Per Capita Out-of-Pocket Health Care Spending, in Total and As a Share of Total Spending, 1965-2010

Chart 17: Trends in Out-of-Pocket Spending as a Share of Total Health Care Spending, by Major Service, 1970-2008

Percentage of Income, by Age Group, 2009

Chart 19: Percentage of Adults Aged 19-64 with Medical Bill or Accrued Medical Debt Problems, by Income Level, 2007

Chart 20: Medical Debt at Bankruptcy Filing, by Health Insurance Status, 2007

Chart 21: Trends in the Number of Uninsured, by

Race and Ethnicity, 1986-2010

Chart 22: Trends in the Percentage of the US Population Insured by Private Employers, Medicare, and Medicaid, 1990-2009

Chart 23: Reasons for Passing Up a Job Opportunity or Postponing Retirement Based on Health Benefits, 2004

Chart 24: Potential Uses of Excess Household Health Care Spending, 2008: \$80 Billion (\$698 per Household)

Chart 12: Trends in Employer Insurance Plan

Deductibles, by Firm Size, 2002-2009 


\section{Contents (continued)}

\section{PART IV: Government: Financial Burden of Health Care Spending}

61

Key Findings: Government Financial Burden of Health Care Spending

Chart 25: Federal Spending on Health and Other Services, 1965 and 2005

Chart 26: Trends in Shares of State and Local Spending on Health and Other Services, 1980-2008

Chart 27: Health Care and Other Major Federal Tax

Expenditures, 1990 and 2010

Chart 28: The Medicare Subsidy for Retirees, 1960, 2010, and 2030

Chart 29: State Wealth and Taxpayer Medicaid Spending Burden, 2005

Charts 30 and 31: Potential Uses of Excess Federal and State Health Care Spending, 2008

Chart 32: Cumulated Invested Excess Health Care Spending: Businesses, Households, the Federal Government, and State/Local Governments, 1991-2008

\section{References, by Chart}

\section{PART V: Health Benefits from Health}

\section{Care Spending}

Key Findings: Health Benefits from Health

Care Spending

Chart 33: Trends in US Life Expectancy at Birth,

Whites and Blacks, 1981-2007

Chart 34: Trends in Infant Mortality per 1,000 Births, Whites and Blacks, 1980-2007

Chart 35: Variation in Infant Mortality Rates, by State and Insurance Coverage, 2007

Chart 36: Trends in Age-Adjusted Death Rates per 100,000 from Heart Disease and Cancer, 1981-2007

Chart 37: Variation in Death Rates Due to Heart Disease, by State and Insurance Coverage, 2007

Chart 38: Variation in Sigmoidoscopy or Colonoscopy Rates in Adults Aged 50 and Older, by State and Insurance Coverage, 2010

Chart 39: Comparison of Health Care Quality, Access, and Costs in Selected Industrialized Countries, 2009 
During the past 50 years, spending on health care services-by households, private businesses, and state and federal governments-increased dramatically and now approaches one out of every five dollars spent in the United States. The benefits of health care spending have not been distributed equally across the population, with less going to a growing number of uninsured people. Moreover, the United States does not realize proportional value for its spending on health care. It spends more per capita than any of six other industrialized countries but ranks below them on measures of health care quality, efficiency, and equity.

Unable to sustain rising contributions to health insurance, employers are shifting more of the cost to workers, thereby increasing the number who cannot afford coverage. Federal, state, and local governments have taken on some of these costs by subsidizing the health services of elderly, disabled, and poor people. Health spending, once a small fraction of the federal budget, now exceeds spending on defense or Social Security. State and local governments now devote more of their own taxes to health care than to elementary and secondary education, despite the federal government's paying for the majority of Medicaid spending.

The data in this chartbook indicate that the financial burden of health care spending presents a disproportionate burden on uninsured and sick people, small businesses, and low-wage workers. In addition to the magnitude and maldistribution of health spending, society's "opportunity costs" are high: Private businesses, households, and state and federal governments could have made other highly productive purchases had health spending not exceeded economy-wide growth. For the government, health care spending decreases the money available for other investments, such as education, infrastructure, and debt reduction. As health costs increase and the population ages, the historical reallocation of US productive capacity to health care is unsustainable. With pressing needs elsewhere, the country must make the health system more efficient, equitable, and affordable.

Passage of the Patient Protection and Affordable Care Act (ACA) by Congress in 2010 was a comprehensive step to contain health care costs, particularly for families, while extending health care coverage to millions of uninsured people. The potential benefits of the ACA include better access to health professionals and prescription drugs, decreased medical debt and fewer subsequent bankruptcy filings, and lower labor costs for small businesses. Constrained health care spending will allow businesses and government to make more cost-effective investments elsewhere without raising prices or burdening taxpayers. With this chartbook as a baseline, users can monitor changes that result from the ACA and take future steps to enhance the cost-effectiveness of the US health care system. 


\section{Introduction}

Remarkable new medical devices, drugs, and biological discoveries in the last 50 years have extended life at higher quality than ever in human history, but these advances have come at an extraordinary cost, \$2.59 trillion in 2010 alone (Centers for Medicare \& Medicaid Services [CMS], 2012). The US health care sector, today, would rank as the fifth largest economy in the world (CIA, 2012). Every hour of every day of the year, Americans spend $\$ 300$ million on health care services (CMS, 2012), but spending on health tells only part of the story.

A truer economic measure of the "cost" of health care spending is the unrecorded opportunity costs of what we as individuals give up each year for better health. In 2010, health care spending in the US increased $\$ 98$ billion, a figure that equals annual total federal spending on homeland security and education combined and is 14 times federal spending on the National Science Foundation, which supports basic science in America. Now that health care spending is approaching one out of every five dollars spent in America, the cost in terms of foregone goods and services elsewhere in the economy is being felt in the form of fewer school teachers, lower wages, higher taxes, and state and federal deficits. But because health care spending is funded in so many different ways across businesses, households, and government, the extent of the financial burden that, ultimately, falls entirely on US citizens has been lost. Because users of health care services pay only a fraction (12 percent, CMS, 2012) of the true cost of services out-of-pocket at the point of service, they cannot appreciate the spillover costs borne by society as a whole.

Why has spending on health care risen so fast for so long? Expanding health insurance coverage, particularly after the passage of Medicare and Medicaid in 1965, produced rapidly rising payments and profits to providers and drug and device manufacturers (Somers \& Somers, 1977, selection 16). Providers began competing for patients and skilled clinical labor by adopting new technologies that resulted in more admissions, more testing, more operations, and many more physician visits (Feldstein, 1979; Newhouse, 1970; Office of Technology Assessment [OTA], 1984, chapter 5). And practically all of the extra costs were passed along in public and private cost-based payment plans. Recognizing that providers could easily pass along costs to third-party payers, manufacturers began developing more quality-improving, life-extending technologies. New drugs and devices resulted in new services, utilization, and higher costs (Altman \& Wallack, 1977; OTA, 1984). Eventually, second- and third-generation technologies came online, e.g., CT scanners, MRIs, cardiac catheterization, ultrasound, PET scanners. These services not only dramatically raised costs and insurer payments, they reinforced consumers' demand, via physician recommendations, for the latest quality-improving, life-saving technologies.

Now, this feedback loop is no longer sustainable. Rapidly rising health costs have been incorporated into higher and higher premiums. As premiums have risen, larger firms have required greater contributions (copremiums) from employees, while smaller employers have given up insurance entirely, as we show in Part 2. With burdensome co-premiums, fewer workers could afford to take up insurance when offered at their workplace. Public sector insurance has picked up many of the uninsured, but approximately 50 million, or one in six Americans, are without health insurance. Policy makers can mitigate the inflationary effects of deeper insurance coverage on costs, but this will require major reforms in the way providers are paid and how new health technologies are covered by insurance. 


\section{Goal of This Chartbook}

The primary goal of this chartbook is to inform citizens and policy makers of the magnitude and distribution of the health spending burden and the need to "bend the cost curve" to make the health system more efficient, equitable, and affordable. As we show in the graphs that follow, the costs to society are not just another billion dollars for MRI scans or a trillion dollars for hospitalizations. America's real costs are measured in less spending on education, shrinking investments in repairing the country's infrastructure, and a generation of innovative scientists bringing forth new goods and services in other fields than health care.

A second chartbook goal is to establish a baseline to monitor changes in the health care financial burden that result from passage of the Patient Protection and Affordable Care Act (ACA) by the Congress in 2010. Slowing payment increases, reinforcing value-based purchasing, and changing private health insurance coverage are a few of the many ways the Act could reduce the cost burden and make it fairer to those less able to pay. It is also hoped that well-designed cost containment initiatives will free up resources for businesses and government to raise wages, lower taxes, innovate, and provide more of the other crucial services that the public, and economy, need.

\section{Organization of the Chartbook}

This chartbook is presented in five parts, each of which opens with selected points supported by the charts in that section. Part I sets the stage with charts on the overall growth in health care spending, its share of gross domestic product (GDP), and the accelerated share of spending by the federal government. This is followed in Part II by measures of the employer and employee financial burden that track rising insurance premiums and deductibles, slower wage growth, declining employer coverage, and fewer employees taking up insurance when offered. Part III quantifies the household financial burden of rising out-of-pocket health care costs, the amount of income spent on health care by age and income group, the growing number of uninsured, and the link between extraordinary medical expenses and personal bankruptcy.

Quantifying the government's financial burden is the goal of Part IV. There, we show the growing responsibility of federal, state, and local governments in paying for health care and how this is "crowding out" spending on education and many other services by heavily subsidizing the health care of elderly and disabled beneficiaries. The unequal taxpayer burden across states in funding health care for the poor is also highlighted. Each of these parts concludes with examples of the opportunity costs of failing to control health care spending. What could households have enjoyed had spending been controlled over the last few decades? What could businesses, states, and the federal government have bought with the extra money?

Everyone recognizes that greater health care spending has also bought better health care, albeit at a high price. Acknowledging the demonstrable gains from a growing health care sector, Part V presents some of the key benefits of health care spending. What effects have greater health spending had on life expectancy, infant mortality, and preventive testing? While gains have been impressive, how equally have gains in access to care been distributed over different populations? And, finally, how does the US health care system compare with those in other industrialized countries? Have the gains in health in America matched those elsewhere? Could they have been achieved at lower cost? 


\section{Introduction (continued)}

Two themes reappear in the charts:

- First is the unequal financial burden of health care spending borne by the uninsured and sick, by small businesses and workers, and by citizens, depending on where they live and where they work.

- Second is the unsustainable reallocation of US productive capacity to health care.

The financial burden of rising health care costs falls on all citizens but presents a disproportionate burden on those least able to pay. Moreover, a growing portion of health care spending is going to the Medicare program, covering the over- 65 population. In the past, intergenerational transfers of resources from younger to older Americans have been justified by the fact that we all get older and will make our own call on health services. But with the projected rapid aging of the population in the next decade (Social Security and Medicare Boards of Trustees, 2012), it is questionable that the younger population, faced with stagnant wages and higher taxes, can continue to fund the rising spending on the elderly outside the workforce. Charts vary in the years that they cover. Many series begin fairly recently due to the lack of readily available data earlier on. A few charts reach back further in time to put spending trends in a longer historical perspective. When spending is adjusted for inflation, it is noted in the chart and accompanying text.

The data file that accompanies this chartbook is available from the RTI Press website.

\section{References}

Altman, S., \& Wallack, S. (1979). Technology on trial-is it the culprit behind rising health costs? The case for and against. In S. Altman and R. Blendon (Eds.), Medical Technology: The Culprit Behind Health Care Costs? (pp. 24-38). Proceedings of the 1977 Sun Valley Forum on National Health. Washington, DC: US Department of Health, Education, and Welfare.

Centers for Medicare \& Medicaid Services. (2012). National health expenditures by type of service and source of funds: CY 1960-2011. Retrieved from http://www.cms. gov/Research-Statistics-Data-and-Systems/StatisticsTrends-and-Reports/NationalHealthExpendData/ NationalHealthAccountsHistorical.html

Central Intelligence Agency. (2012). The world factbook. Retrieved from https://www.cia.gov/library/publications/ the-world-factbook/index.html

Feldstein, P. (1979). Health care economics. New York: John Wiley \& Sons.

Newhouse, J. (1970). Toward a theory of nonprofit institutions: An economic model of a hospital. American Economic Review, 8(1), 64-74.

Office of Technology Assessment. (1984). Medical technology and costs of the Medicare program. Washington, DC: US Government Printing Office.

Social Security and Medicare Board of Trustees. (2012). Status of the Social Security and Medicare Programs: A summary of the 2012 annual reports. Washington, DC: US Social Security Administration. Retrieved from http:// www.ssa.gov/oact/TRSUM/index.html

Somers, A., \& Somers, H. (1977). Health and health care: Policies in perspective. Germantown, MD: Aspen Systems Corporation. 


\section{PART I \\ Introduction: Growth in Health Care Spending}





\section{Dey Findings: Growth in Health Care Spending}

- From 1960 to 2010, total health care spending, unadjusted for inflation, increased 95 -fold in the United States from $\$ 27.4$ billion to $\$ 2.59$ trillion, far outstripping the nominal growth in spending on all goods and services.

- Even after adjusting for inflation, spending on all forms of health care increased roughly 13 -fold over 50 years.

- Total health spending as a share of GDP rose continually from 5.2 percent annually in 1960 to 17.9 percent by 2010 .

- In 1960, $\$ 19.23$ was spent in the economy for every dollar spent on health. That number had fallen to just $\$ 5.58$ by 2010 .

- Health care spending by households, $\$ 253$ billion in 1990, nearly tripled to $\$ 726$ billion by 2010 . Yet, despite remarkable growth, households' share of health spending actually fell from 38 percent to 30 percent, with businesses and governments experiencing rising shares.
- Private business spending on health also increased 3-fold in 20 years, but after its share of total spending peaked at 27 percent in 2000 , its share declined quickly to 22 percent by 2010 .

- Between 1990 and 2010, states' share of health spending increased slightly less than 1 percentage point to 17 percent, despite the fact that their spending increased from $\$ 111$ billion to $\$ 421$ billion.

- Federal health care spending, $\$ 125$ billion in 1990 , reached $\$ 743$ billion in 2010, a 6-fold increase. 


\section{Chart}

\section{Trends in National Health Expenditures (NHE) as a Share of Gross Domestic Product (GDP), 1960-2010}

\section{The Numbers}

From 1960 to 2010, total health care spending, unadjusted for inflation, increased 95 -fold in the United States from $\$ 27.4$ billion to $\$ 2.59$ trillion (Table 1), far outstripping the nominal growth in spending on all goods and services. Just between 2000 and 2010, health care spending increased 88 percent, implying a near doubling of spending yet again by 2020, and without taking the accelerated aging of the population into account. After adjusting for inflation, spending on all forms of health care increased roughly 13 -fold over 50 years.

Health care spending has risen almost every year as a share of GDP, as shown in Table 1 and Chart 1 (bold line). Total health spending as a share of GDP rose continually from 5.2 percent annually in 1960 to 17.9 percent by 2010 . In $1960, \$ 19.23$ was spent in the economy for every dollar spent on health (CMS, 2012) That number had fallen to just $\$ 5.58$ by 2010 . The rate of health care spending continues to rise from a larger and larger base, with another $\$ 1.2$ trillion added in just the last 10 years. Chart 1 also shows the percentage growth in NHE and GDP. In almost every year, growth in spending on health care exceeded growth in the general economy. Even before Medicare and Medicaid were enacted in 1965, health care spending was growing faster than GDP. For the next 15 years after 1965, NHE grew several percentage points faster than GDP. By 1983, NHE's share of the economy had reached 10.4 percent. Then, over the brief 1983-1986 period, NHE tracked the growth in GDP fairly closely. This was followed again by a 7-year period of exceptional NHE growth. Health spending from
1994 through 2000 returned to roughly the growth in GDP, followed by several years of excess growth in the early 2000s once again. When the economy went into recession in 2000, NHE growth, while below historical averages, did not follow the economy into decline. Nor did NHE follow the decline in GDP in the 2008 recession; instead, it added a full percentage point to NHE's share of the economy in 2009.

\section{Commentary}

The exceptional growth in health care spending, at first manageable when health spending was only 5-7 percent of GDP, now at 18 percent is outstripping the growth in the productive capacity of the country to support it. While the country's productive output experiences positive and negative swings, health care spending always increases. It might rise more slowly in a recession, but it never falls. Particularly troublesome is the fact that the largest disparities in the two growth rates come in periods of slower GDP growth (i.e., 1976-82, 1984-91, 2005-09). Thus, while NHE tracks GDP to some degree because both are influenced by economy-wide inflation, the "burden" of health care grows disproportionately in times when businesses, households, and taxpayers are least able to pay for care. Now that health care spending is almost $\$ 1$ in $\$ 5$ in the overall economy (see solid dark line in Chart 1), if left unconstrained, it will impose even greater opportunity costs on society in the future in terms of fewer private goods and less spending on education, highways, and other public services. 
Table 1. Trends in national health expenditures (NHE) and its share of GDP

\begin{tabular}{lrrr} 
Year & $\begin{array}{r}\text { Total nominal NHE } \\
\text { (\$billions) }\end{array}$ & $\begin{array}{r}\text { Total 1960 NHE } \\
\text { (\$billions) }\end{array}$ & NHE/GDP \\
\hline 1960 & $\$ 27.4$ & $\$ 27.4$ & $5.2 \%$ \\
\hline 1970 & $\$ 74.9$ & $\$ 57.1$ & $7.2 \%$ \\
\hline 1980 & $\$ 255.8$ & $\$ 91.9$ & $9.2 \%$ \\
\hline 1990 & $\$ 724.3$ & $\$ 164.0$ & $12.5 \%$ \\
\hline 2000 & $\$ 1,377.2$ & $\$ 236.7$ & $13.8 \%$ \\
\hline 2010 & $\$ 2,593.6$ & $\$ 352.0$ & $17.9 \%$ \\
\hline Increase $1960-2010$ & 94.8 -fold & 12.9 -fold & $3.4-$ fold \\
\hline
\end{tabular}

\section{Notes}

Nominal NHE $=$ spending in current year dollars; $1960 \mathrm{NHE}=$ spending in 1960 dollars.

\section{Source}

Centers for Medicare \& Medicaid Services (2012), national health expenditures by type of service and source of funds, CY1960-2010.

\section{Chart 1. Trends in national health expenditures (NHE) as a share of gross domestic} product (GDP), 1960-2010

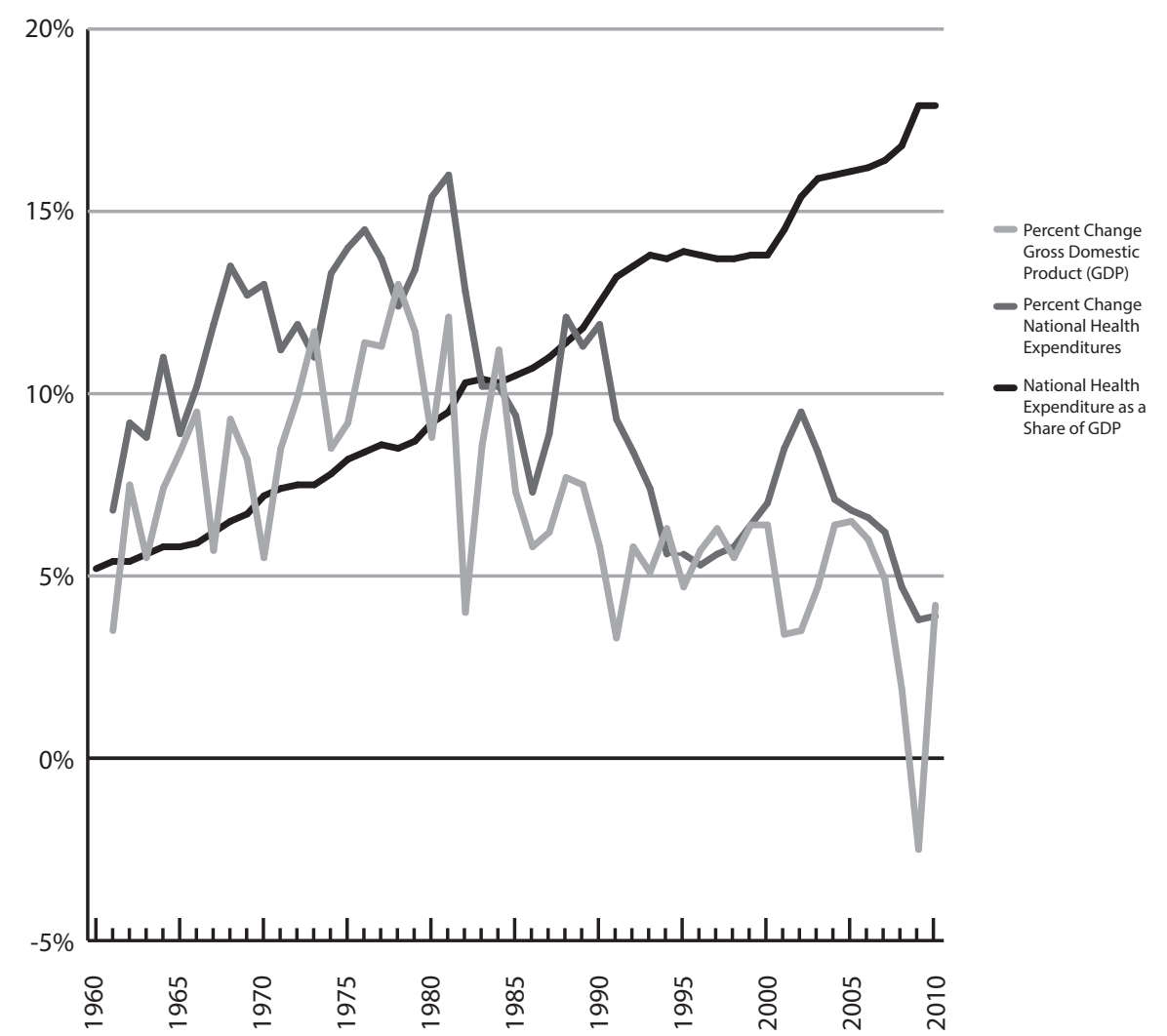

\section{Note}

Percentages based on undeflated dollars.

\section{Source}

CMS (2012), national health expenditure data. 


\section{Chart Chart 23}

\section{Trends in Health Care Spending and Shares of Health Care Spending, by Source of Funds, 1990-2010}

\section{The Numbers}

As health care has taken up an increasing percentage share of the US economy, the burden of paying for care has risen for all four major sources of payment: (1) private businesses, (2) the federal government, (3) state and local governments, and (4) individuals and households. Chart 2 shows the trend in unadjusted spending for each source over the period 1990 to 2010. Chart 3 shows the trend for the four sources as a percentage of total health spending.

According to the Medicare actuaries, households (single individuals and families) have always borne the greatest burden for health care. In 1990, householdsthrough their employer and individual insurance premiums, tax contributions directly earmarked to Medicare, and out-of-pocket payments-were responsible for $\$ 253$ billion of the $\$ 724$ billion in total health spending (Chart 2; CMS, 2012; see CMS Methodology for included items). Twenty years later, their burden had risen to $\$ 726$ billion, a 2.9 -fold increase. Yet, despite remarkable growth, households' share of health spending actually fell from 38 percent to 30 percent (Chart 3 ). Similarly, private business spending increased 3 -fold in 20 years through a combination of employer-paid premiums, matching Medicare taxes, and workers' compensation insurance. This growth, too, was not enough to maintain business' share of health spending. From a peak share in 2000, private business' share of health costs had declined to 22.1 percent by 2010 .

State government spending made up only slightly for the declining household and business shares of health care costs ( 0.8 percent increase in its share), despite the fact that states' spending increased from $\$ 111$ billion to $\$ 421$ billion. In 1990, state employee health premiums, states' share of Medicaid, and public health program outlays were 62 percent of outlays by private businesses. By 2010, states were spending 80 percent of what businesses were spending on health care.
The federal government followed a far more accelerated spending path than the other funding sources. It saw its spending rise from $\$ 125$ billion in 1990 to $\$ 743$ billion in 2010, a 6-fold increase. Federal health spending includes Medicare outlays net of payroll taxes and premiums, the major part of Medicaid spending, and premiums for government employees and other health programs (e.g., the National Institutes of Health). As recent as 1990, federal spending was only 18.8 percent of all health spending. Twenty years later, its share had reached 30 percent and had overtaken the burden of households.

Only in the period 1996-2000 did the share of household and business spending rise while the share of federal spending fell. This was a period of relatively strong growth in the US economy, with low unemployment and modest increases in Medicaid spending coupled with greater Medicare tax revenues. After 2000, federal spending again was the primary driver of spending on health in the US. In the 3 recessionary years 2008-2010, the federal share rose 5.6 percentage points, which was more than the declining share for businesses over 20 years.

\section{Commentary}

Charts 2 and 3 tell two stories. On the one hand, the health care spending burden continues to rise for all four major funders of health services. No group is exempt. On the other hand, private spending has rarely grown faster than public spending-especially by the federal government. Private employer and direct purchase insurance coverage peaked in 2000 and has been in decline ever since. The elderly, the poor, the disabled, and government workers have been the primary beneficiaries of greater health spending on their behalf, as shown in Part IV. 
Chart 2. Trends in health care spending, by source of funds, 1990-2010

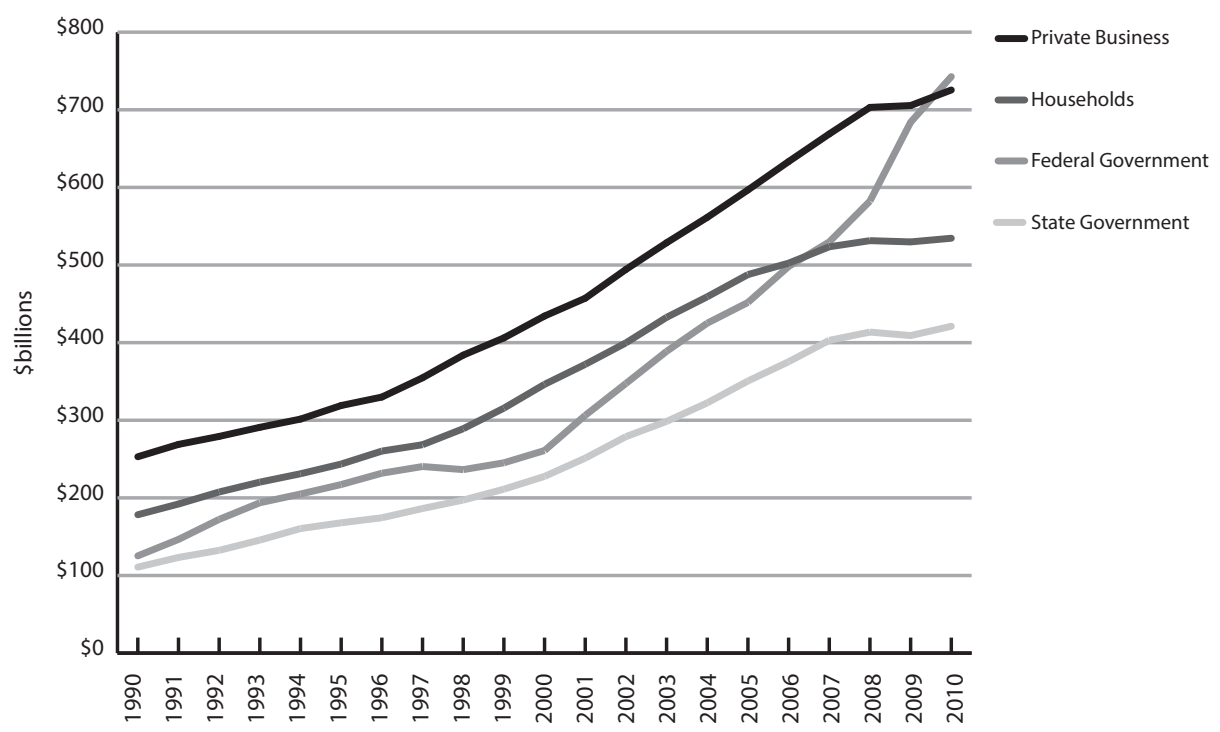

Chart 3. Trends in shares of health care spending, by source of funds, 1990-2010

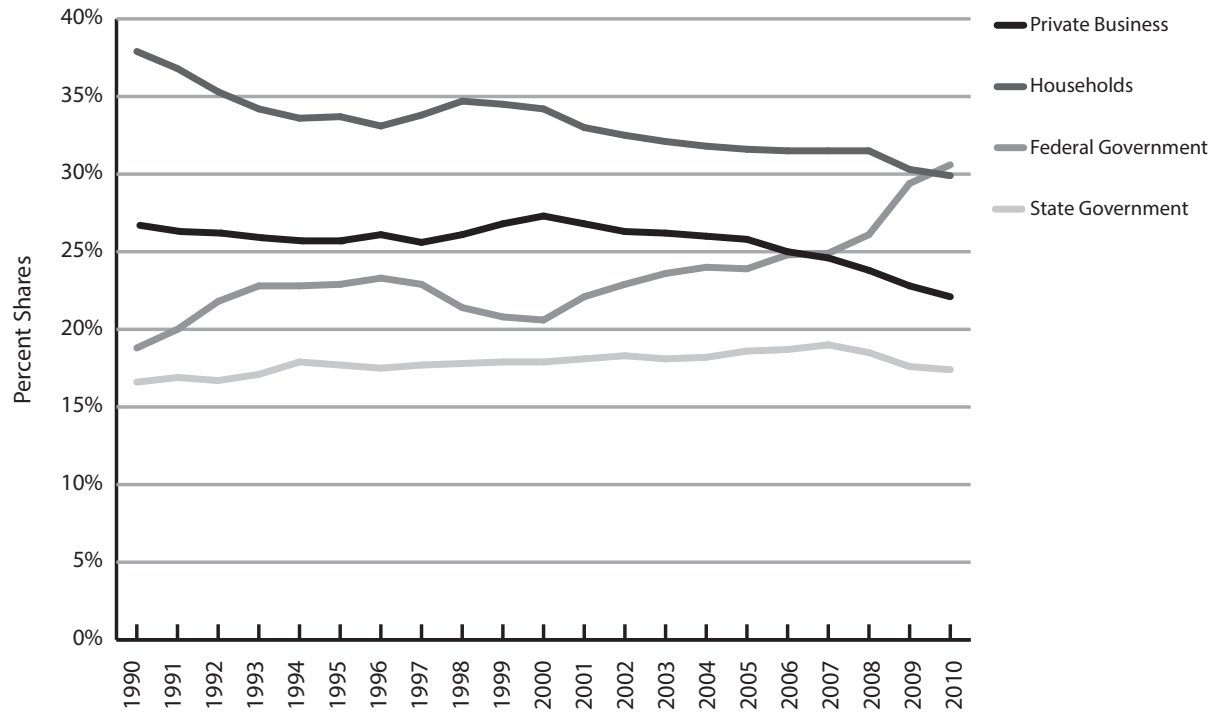

\section{Source}

Centers for Medicare \& Medicaid Services (2012), national health expenditure data. 
Page deliberately left blank. 


\section{PART II \\ Business: Financial \\ Burden of Health Care \\ Spending}




\section{Dey Findings: Business Financial Burden of Health Care Spending}

- Unadjusted for inflation, private businesses in the US spent $\$ 387.8$ billion on health services in 2008 ; three-quarters was for health insurance premiums for employees.

- From 1990 to 2008, unadjusted business health care spending on premiums per full-time equivalent employee (FTE) more than doubled from $\$ 1,502$ to $\$ 3,590$. After 2005, employers' contributions to health care spending actually decreased on an inflation-adjusted basis.

- Inflation-adjusted (2008) wages increased only three-quarters of 1 percent per year between 1990 and 2008. At recent rates of wage growth, it will take 130 years for workers to double their standard of living out of wages and salaries alone.

- Over the same period, total health benefits per employee rose 2.3 times faster than wages. The net effect was a 20 percent rise in the ratio of health benefits to wages.

- Two automatic adjustors keep American businesses competitive internationally in the face of rising employer health premiums. First, flexible exchange rates narrow product cost differences across countries. Second, America's large secular trade deficit has kept the dollar relatively devalued, and American wages competitive internationally.
- In 2010, employer health insurance costs were 11 percent of total compensation in the transportation industry compared with a much smaller 6 percent to 7 percent in the services and retail trade industries. Lower-wage retail and service workers take more of their compensation in the form of wages and salaries than in health benefits and are more likely to work part-time, which makes them less eligible for health coverage.

- In 2009, 96 percent of firms with 50 or more employees offered health insurance compared with only 41 percent of firms with less than 50 employees. Small firms with fewer than 50 employees and a majority of low-wage workers were only one-half as likely (22 percent) as all small firms (41 percent) in general to offer health insurance.

- ACA tax credits for offering health insurance will save small businesses nearly $\$ 40$ billion from 2010 to 2019, although they must pay at least 50 percent of the health premium to qualify. 
- In 1996, 70 percent of employees were enrolled in employer health insurance plans. By 2009, enrollment rates, when insurance was offered, were 10 percentage points lower. Declines occurred across all firm sizes. With wages up only 3 percent in real terms between 2000 and 2008, fewer low-wage and part-time workers were able to afford health insurance-even when it was offered by their employer.

- From 1996 to 2002, the employee premium share stayed roughly constant in single coverage plans and fell slightly for family coverage. After 2003, the employees' premium share rose 10-20 percent across firm sizes and plan types.

- Between 1999 and 2006, employees' portion of average monthly premiums for family coverage increased 44 percent for full-time workers (from \$204 to \$294). Over the same time period, employers' premium costs grew 27 percent for full-time workers.

- Between 2002 and 2009, average plan deductibles, in 2009 dollars, increased by $55-78$ percent across plan types and firm size.
- By 2009, three of four large employers no longer offered health insurance to their early retirees, and essentially all small firms have eliminated the benefit. The ACA includes a temporary (through 2013) reinsurance program for employers providing health insurance coverage to retirees over age 55 who are not eligible for Medicare.

- "Excess" health care spending can be defined as the growth of business health spending that exceeds the growth in GDP. If business' spending on health care services had grown only at the rate of GDP since 1990, in 2008 alone businesses would have saved an extra $\$ 92$ billion to spend in different ways, including

- giving each worker a 48 percent higher raise, or instead

- increased their research and development budget by 34 percent, or simply enjoyed

- pre-tax profits 7 percent higher. 


\section{Chart}

\section{Trend in Business Health Care Expenditures per Employee, 1990-2008}

\section{The Numbers}

Chart 4 shows the growth in health care spending per full-time equivalent (FTE) employee both before and after adjusting for Consumer Price Index (CPI) inflation. Any increase after adjusting for inflation reflects labor costs not successfully passed on to consumers in the form of higher prices. Health insurance contributions (premiums) per employee represent total business contributions nationwide divided by the number of FTE employees, whether or not they are covered by their employer's plan.

Unadjusted for inflation, private businesses in the US spent $\$ 387.8$ billion on health services in 2008 (CMS, 2008; Bureau of Economic Analysis [BEA], 2009; Bureau of Labor Statistics [BLS], 2011). Three-quarters of this cost was for health insurance premiums for employees (CMS, 2008; BEA, 2009; BLS, 2011). Employer-paid premiums across all FTE employees, whether covered or not, averaged $\$ 3,590$ in 2008 (Table 4). Businesses pay their portion of Medicare taxes to support hospital care for the elderly, the medical portion of workers' compensation and temporary disability insurance, and on-site industrial health services.
From 1990 to 2008, inflation-adjusted business health care spending on premiums per FTE rose 45 percent from $\$ 2,476$ to $\$ 3,590$ (Table 4). Employers' premium burden per employee grew particularly fast over the 1997-2005 period. Then, after 2005, employers' contributions to health care spending actually decreased by 5 percent on an inflationadjusted basis. Medicare insurance costs for employers generally followed employer premiums. Workers' compensation costs, however, actually fell over the 18year period.

\section{Commentary}

Continued growth in employer-paid premiums has recently proved unsustainable. After 2005, as insurer health premiums continued to rise, employers began reducing their contribution in various ways, including dropping retiree coverage and raising employees' premium contributions and deductibles (see Charts 10,12 , and 13). It is quite likely that the downward trend in inflation-adjusted employer-paid premiums continued, and may have accelerated, during the recession beginning in 2008.

Table 4. Trends in employer health care costs per employee, 1990-2008

\begin{tabular}{|c|c|c|c|c|c|c|c|}
\hline & 1990 & 1997 & 2005 & 2008 & $\begin{array}{l}\text { Percent } \\
\text { change } \\
1990-2008\end{array}$ & $\begin{array}{l}\text { Percent } \\
\text { change } \\
2005-2008\end{array}$ & \\
\hline $\begin{array}{l}\text { Employer contribution to } \\
\text { private health insurance } \\
\text { premiums }\end{array}$ & $\$ 2,476$ & $\$ 2,658$ & $\$ 3,783$ & $\$ 3,590$ & $45 \%$ & $-5 \%$ & \\
\hline $\begin{array}{l}\text { Employer contribution to } \\
\text { Medicare Hospital Insurance } \\
\text { Trust Fund }\end{array}$ & $\$ 566$ & $\$ 687$ & $\$ 756$ & $\$ 765$ & $35 \%$ & $1 \%$ & Note \\
\hline $\begin{array}{l}\text { Workers' compensation and } \\
\text { temporary disability insurance } \\
\text { and industrial in-plant health } \\
\text { services }\end{array}$ & $\$ 370$ & $\$ 347$ & $\$ 388$ & $\$ 360$ & $-3 \%$ & $-7 \%$ & $\begin{array}{l}\text { Figures in } 2008 \text { dollars. } \\
\text { Sources } \\
\text { Centers for Medicare \& Medicaid } \\
\text { Services (2008); Bureau of Economic }\end{array}$ \\
\hline Total & $\$ 3,412$ & $\$ 3,693$ & $\$ 4,928$ & $\$ 4,715$ & $38 \%$ & $-4 \%$ & $\begin{array}{l}\text { Analysis (2009); Bureau of Labor } \\
\text { Statistics (2011). }\end{array}$ \\
\hline
\end{tabular}




\section{Chart 4. Trend in business health care expenditures per employee, 1990-2008}
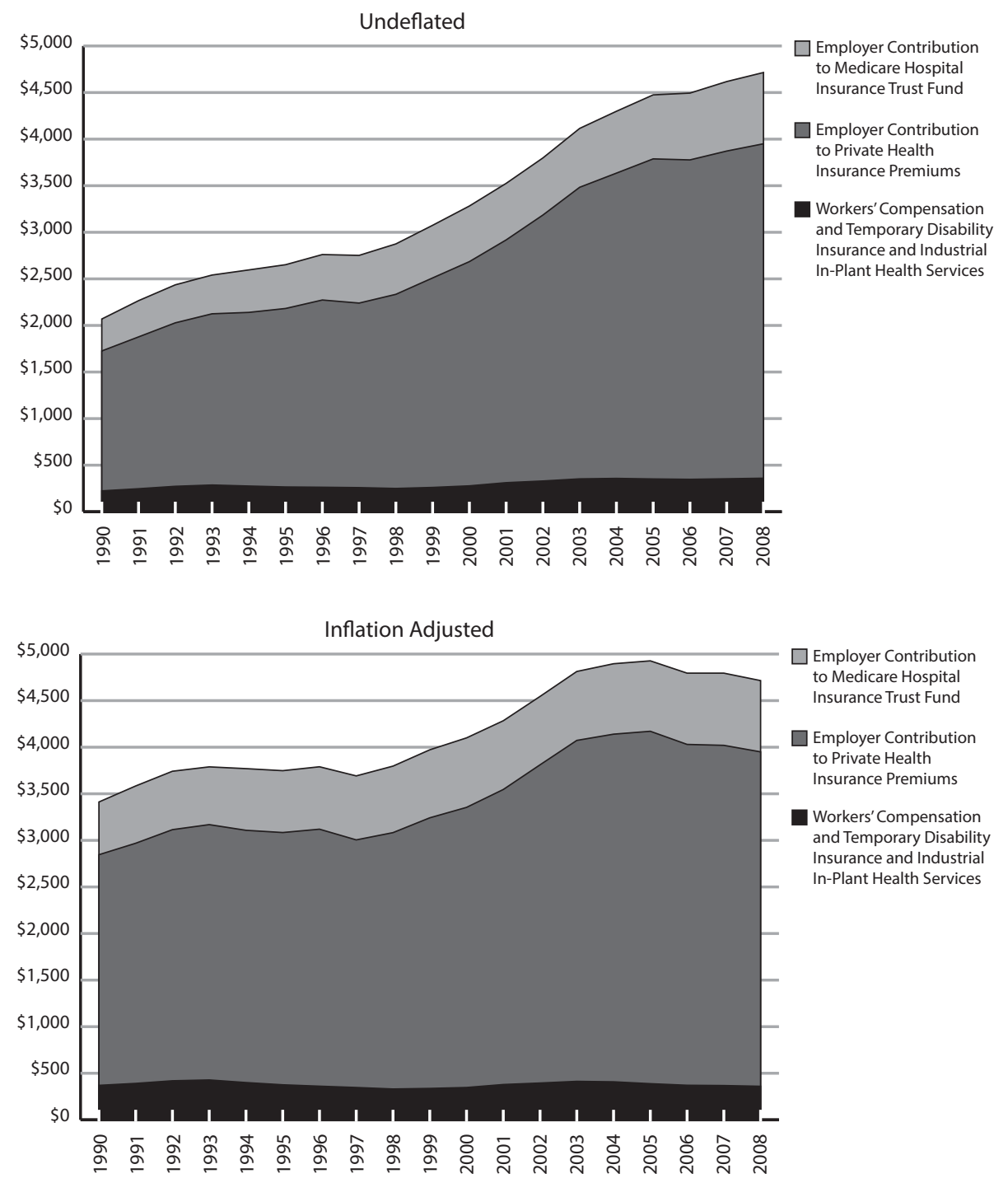

\section{Note}

Expenditures in 2008 dollars.

\section{Sources}

Centers for Medicare \& Medicaid Services (2008); Bureau of Economic Analysis (2009); Bureau of Labor Statistics (2011). 


\section{Chart \\ Trends in Wages and Salaries and the Ratio of Health Benefits to Wages, 1990-2008}

\section{The Numbers}

Chart 5 shows inflation-adjusted (2008) total wages and salaries per FTE over the period 1990-2008 (left axis), along with the ratio of health benefits to wages and salaries (right axis). Real wages increased only three-quarters of 1 percent per year $(\$ 52,777$ to $\$ 60,664$ ) over the 18 -year period through 2008 . Workers enjoyed no material gain in real wages from 1990 through 1996. Over the 1990-2008 period, real total health benefits per employee increased from $\$ 3,412$ to $\$ 4,715$ (Table 4 ), or 1.8 percent per year, 2.3 times faster than wages.

Health benefits, which rose over the 18 years from 6.5 percent of wages to 7.8 percent, followed an uneven upward trend. Health benefits' proportion of wages rose about three-quarters of a percentage point between 1990 and 1996 primarily due to stagnant wages and premium increases of 1.7 percent annually. Between 1996 and 1998 wages began to rise, thereby reducing the ratio of health benefits to wages. From 1996 through 2007, real wages grew 16 percent, yet health benefits still grew as a share of wages until peaking at 8.3 percent in 2005. After 2005, health benefits consistently fell as a proportion of wages before settling at 7.8 percent in 2008. Over the entire 18 -year period, real wages and salaries rose 15 percent compared with roughly a 20 percent rise in health benefits as a portion of wages.

\section{Commentary}

Economic theory (Emanuel \& Fuchs, 2008) predicts that workers will eventually bear the total cost of rising health premiums. Employers make hiring and wage decisions based not just on wages but on total compensation, including fringe benefits. Disappointingly slow growth in wages was a major way in which employers grappled with rapidly rising health premiums. To remain competitive in world markets, US businesses constrained labor costs by slowing wage increases and by "shipping" more jobs overseas, where wages and health costs are far lower (Noah, 2012, chapter 6). At previous rates of wage growth (0.78 percent annually between 1990 and 2008), it would take 130 years for workers to double their standard of living out of wages and salaries alone.

Employer spending on health benefits may also have reached a watershed period in 2005. As shown in charts later in this section, more and more of employers' health cost burden is being shifted to workers in ways other than lower wages. It may be that workers are no longer able to take their compensation in the form of insurance coverage and are demanding higher raises in return. 


\section{Chart 5. Trends in wages and salaries and the ratio of health benefits to wages,}

1990-2008

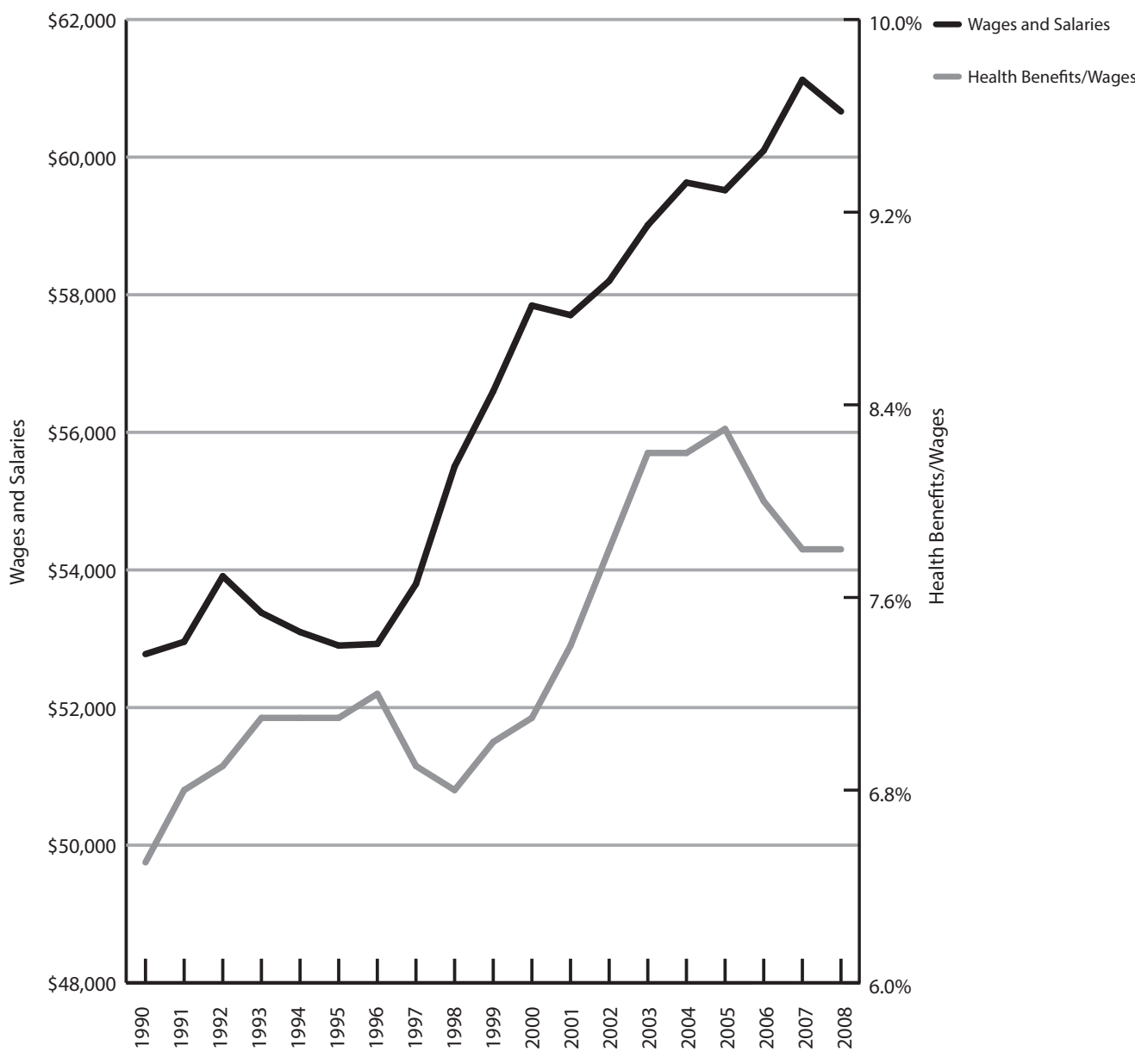

Notes

Expenditures in 2008 dollars

\section{Sources}

Wages and salaries data: Bureau of Economic Analysis (2009); Health benefits data: Centers for Medicare \& Medicaid Services (2012); Full-time equivalent employees data: Bureau of Economic Analysis. (2009); Bureau of Labor Statistics (2011), Consumer Price Index: All urban consumers. 
Chart 6

\section{Trends in Manufacturing Hourly Total Compensation Costs, by Country,} 1990-2008

\section{The Numbers}

Between 1990 and 2008, the cost of inflation-adjusted health care benefits to employers in the US rose 38 percent and the ratio of benefits to wages rose 20 percent. What impact might business' rising health care costs have on their international competitiveness? Chart 6 compares trends in inflation-adjusted real compensation costs for manufacturing workers in the US, Germany, Canada, Japan, Mexico, China, and East Asia. Compensation in other countries has been converted into US dollars at current year exchange rates. Movements in these rates can hinder or enhance the competitiveness of US labor independent of health care costs.

Between 1995 and 2000, total compensation fell sharply in Germany, Canada, and Japan but remained unchanged in the US. Over the more recent 2000-2008 period, real total compensation costs increased by 47 percent in Germany and 42 percent in Canada but barely increased for US production workers (4 percent). As a result, since 2005, US manufacturers have incurred lower labor compensation costs, exchange rate adjusted, than have manufacturers in Germany and Canada and only slightly higher costs compared with Japan. However, the cost of manufacturing labor in 2008 was eight times greater in the US than in Mexico and 18.6 times greater than in China.

\section{Commentary}

Contrary to what one might expect, burdensome health premiums in the US do not appear to put American manufacturers at a competitive disadvantage compared with other highly industrialized countries. One reason is that health care costs still constitute a relatively small portion of business expenses (7-8 percent of employee compensation in 2008; see Chart 5) - in part because many firms do not offer health insurance (see Chart 8). Another is that despite significant differences in their health care systems as a whole, a large portion of the population in Germany, Japan, and other developed countries receive health insurance through their employers, who also face competitive pressures from rising health care costs. This is not true in many developing countries, such as Mexico, where more than half (and often all) of a person's annual health care spending is out-of-pocket (Barraza-Lloréns \& Bertozzi, 2002).

Two automatic adjustors keep American businesses competitive internationally. First, slow wage growth (just 4 percent in 8 years through 2008; Chart 5) absorbs a considerable amount of the rapid growth in health costs. Second, flexible exchange rates narrow product cost differences across countries. For example, the US dollar fell from 0.79 euros on July 23, 2006, to 0.63 euros on July 20, 2008, a 20 percent decline relative to the euro over 2 years (BLS, 2010; OANDA currency charts, http://www.oanda. com/currency/average). During the same time, manufacturing workers went from being 24 percent to 40 percent more costly in Germany than in the US, a change explained entirely by currency fluctuations. America's large annual trade deficit has kept the dollar relatively devalued and American labor competitive internationally, although globalization has taken a toll, especially in low-wage industries. 
Chart 6. Trends in manufacturing hourly total compensation costs, by country, 1990-2008

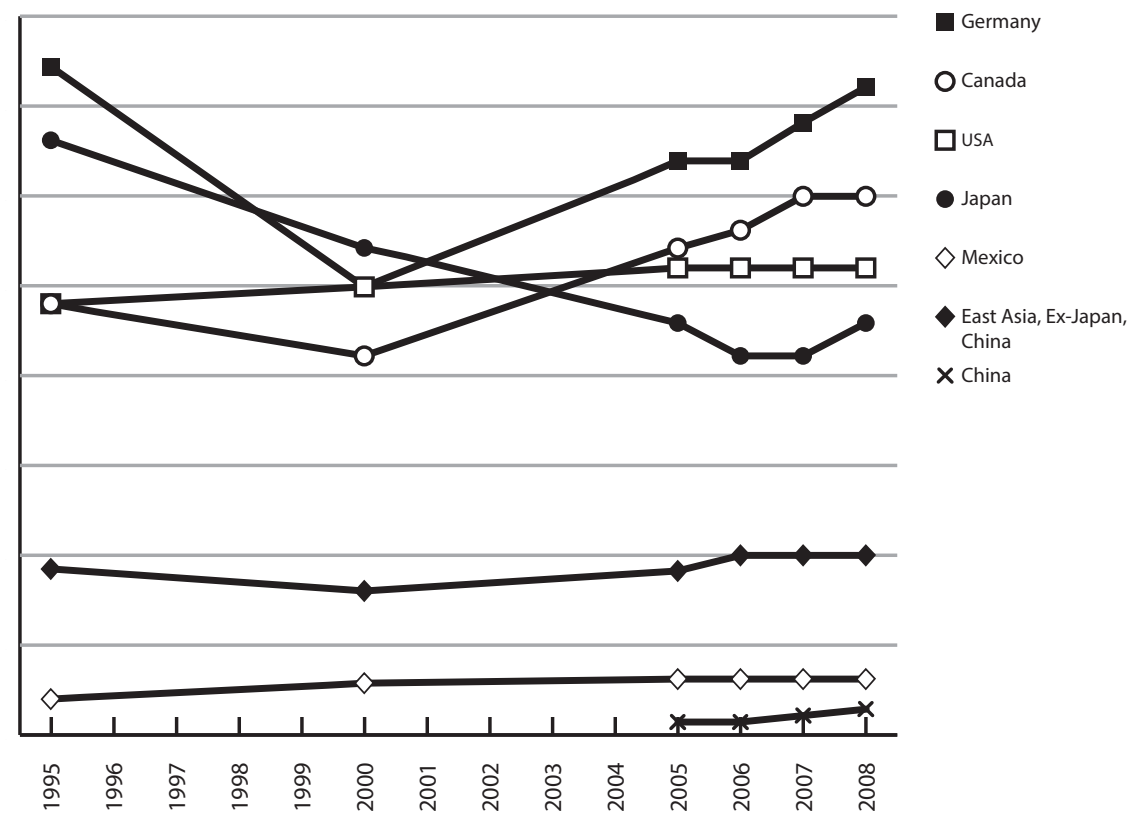

Notes

Costs in adjusted 2008 US dollars. Values interpolated for missing years. Sources

Bureau of Labor Statistics (2010, Aug.; 2013); Congressional Budget Office (2007). 


\section{Chart}

\section{Employer Health Insurance Cost per Labor Hour, by Major Industry,} 2010

\section{The Numbers}

International competition requires most firms to constrain health benefits, wages, or both. Although all employers are concerned about rising health insurance costs, the extent to which the burden falls on them versus their employees differs across industries. Chart 7 shows US employer health insurance costs per labor hour in seven major industries. Transportation, manufacturing, and construction-industries with relatively high wages-bore the highest health insurance cost burden, exceeding \$3 per hour worked. In contrast, service and retail trade industries bore the lowest health insurance cost burden, $\$ 2.13$ and $\$ 1.26$, respectively.

Employer health insurance costs were 11 percent of total compensation in the transportation industry compared with a much smaller 6 percent to 7 percent in the services and retail trade industries (BLS, 2012).

\section{Commentary}

Variations in health costs across industries reflect systematic differences in worker characteristics and wages. For example, unionization and high wages in the transportation, manufacturing, and construction industries may lead to more comprehensive health insurance benefits, with workers taking lower wage increases for deeper coverage. Conversely, lowerwage retail and service workers take more of their compensation in the form of wages and salaries than in health benefits. Low-wage, often minimumwage, workers in the retail trade industry are highly dependent on cash wages for food, shelter, and other necessities. They are also more likely to work part-time, which makes them less eligible for health coverage in the marketplace. 
Chart 7. Employer health insurance cost per labor hour, by major industry, 2010

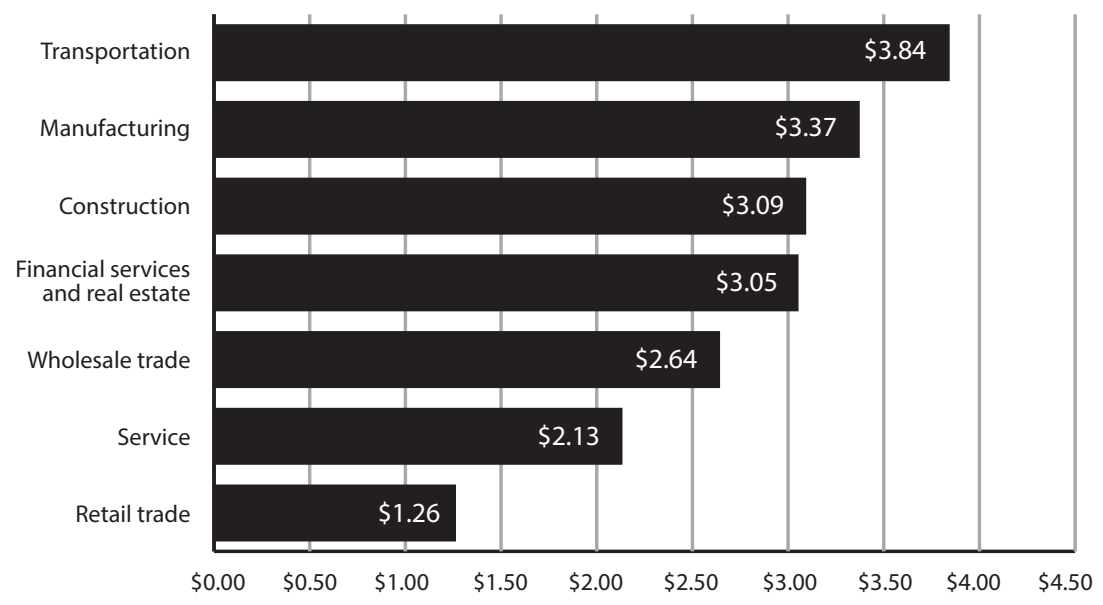

Bureau of Labor Statistics (2010). 


\section{Percentage of Firms That Offer Health Insurance, by Firm Size, 2009}

\section{The Numbers}

While most employers struggle with rising health care costs, the problem is particularly challenging for small employers, who face the highest premiums as a result of higher administrative costs associated with small group plans. Chart 8 shows the percentage of private sector US firms that offered health insurance in 2009, by firm size and share of low-wage employees. There is a clear positive relationship between the size of firms and the likelihood that they offer health insurance. Ninety-six percent of firms with 50 or more employees offered health insurance compared with only 41 percent of firms with less than 50 employees. The fall-off is especially severe in businesses with fewer than 10 employees. Practically all firms with more than 50 employees also offered health insurance regardless of average wages, but small firms with fewer than 50 employees and a majority of low-wage workers were only one-half as likely (22 percent) as all small firms (41 percent) to offer health insurance.

\section{Commentary}

The problem of uninsured workers is seen mostly in small firms, and particularly those with low-paid workers. One reason for lack of coverage is that it is harder for health plans to spread financial risk across small groups. Also, low-wage employees tend to work part-time, are younger, and exhibit high turnover. Over one-quarter of all employees in smaller firms were employed on a part-time basis in 2009 compared with 18 percent for large firms (Agency for Healthcare Research and Quality [AHRQ], 2009). Low-wage, high-turnover employees prefer cash wages rather than health insurance if given the choice. The challenges of small firms with disproportionate numbers of lowwage workers raise serious doubts about linking private health coverage with place of employment.

The large discrepancy in offer rates in small firms with low wages compared to all small firms, on average, is explained, in part, by a sizable group of high-margin, high-wage companies and professionally incorporated contractors (e.g., lawyers, consultants). These small groups do provide employees, including officers, with insurance coverage as a covered business expense.

Under the ACA, tax credits are currently being offered to employers that have fewer than 25 workers and average annual wages less than $\$ 50,000$. For tax years 2010 through 2013, a tax credit of up to 35 percent of the employer's contribution toward the employee's health insurance premium is offered if the employer contributes at least 50 percent of the total premium cost based on the average cost of health insurance in that state. Full tax credits are available to employers with 10 or fewer FTE workers and average annual wages less than $\$ 25,000$. Beginning in tax year 2014, for companies with 10 to 25 workers, a tax credit of up to 50 percent of the employer's premium contribution is offered to employers who participate in their state's small business health insurance exchange. This is intended to help small employers reap benefits similar to those enjoyed by large employers by spreading risk and strengthening bargaining power with insurers. Notably, these tax credits are only available for 2 years, after which point it is hoped that small businesses will continue to participate in the exchange without financial assistance. The Congressional Budget Office (CBO, 2011) estimates that this tax credit will save small businesses nearly $\$ 40$ billion from 2010 to 2019, although they must still pay at least 50 percent of the health premium. If this incentive is effective, there should be an increase in the percentage of small firms that offer health insurance.

Two unintended effects can result from government tax credits: dropping coverage or shifting costs to workers and part-time employees. Starting in 2014, firms with 50 or more employees will be penalized $\$ 2,000$ for each FTE employee who receives a premium tax credit when purchasing health care insurance through the new health insurance exchanges. According to a recent report by McKinsey \& Company 
(2011), many employers may find the penalties less burdensome than the high costs of health coverage. As many as a third of employers may opt to discontinue offering private coverage, knowing that their workers will still enjoy subsidized health insurance. And if health costs continue to rise rapidly, the negative effect of penalties on employers' bottom lines is likely to reinforce the crowding out effect of offering competing public insurance. Employers will be even more inclined to drop coverage and pay the penalty.

Fewer than one-third of employers that offer health insurance to their full-time employees also make it available to their part-time employees (Kaiser Health News, 2010). When forced to choose under the ACA, some employers will likely first raise co-premiums for their part-time employees. In a recent survey of 800 employers by human resources consultant Mercer (Kaiser Health News, 2010), a majority of employers that do not offer insurance to full-time (30+ hour/ week) workers said that they would consider reducing employees' hours starting in 2014 in order to avoid mandated penalties. If this happens, the trend toward part-time work in larger firms would rise again and frustrate the goal of broadening employer-based health insurance. By extension, crude measures of job loss due to the ACA that ignore part-time status would understate the full employment impacts of maintaining employer-based health insurance. Financial penalties in the ACA imposed on firms that do not pay premiums for full-time employees should reinforce any trend of employers to switch full-time workers to parttime workers.

\section{Chart 8. Percentage of firms that offer health insurance, by firm size, 2009}

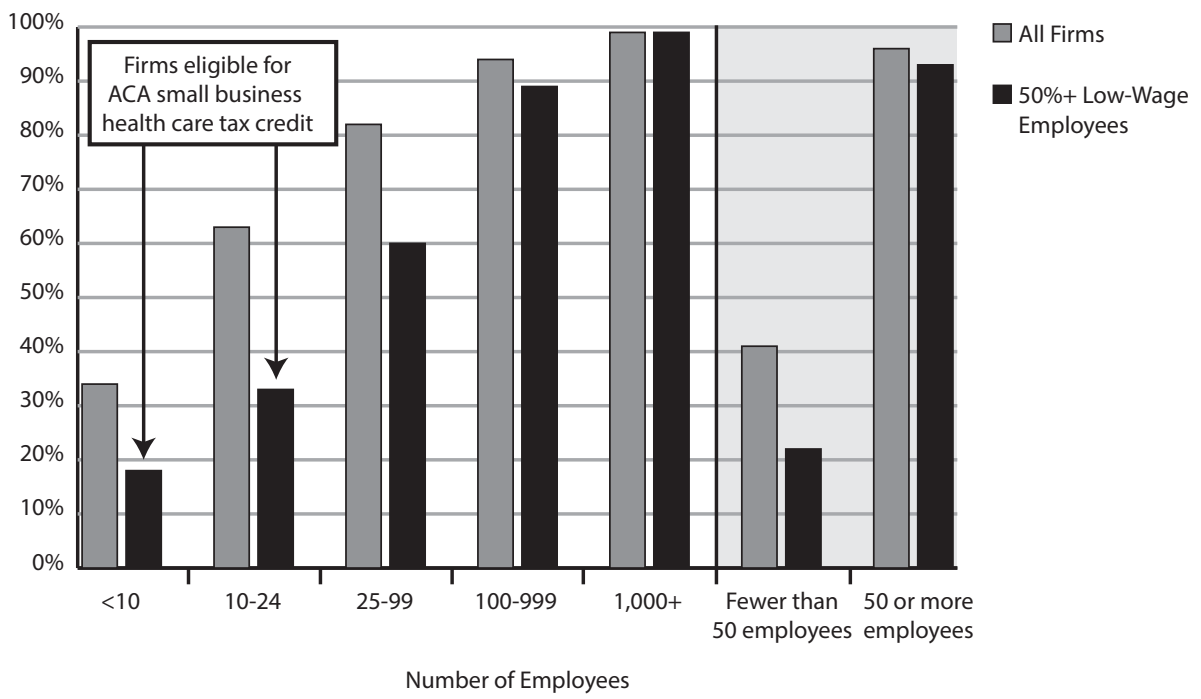

Source

Agency for Healthcare Research and Quality (2009). 


\section{Chart}

\section{Trend in the Percentage of Employees Enrolled in Private Sector Firms That Offer Health Insurance, by Firm Size, 1996-2009}

\section{The Numbers}

The fact that a firm offers insurance does not automatically mean all workers have coverage. Chart 9 plots trends in insurance enrollment rates by firm size in private sector firms that offer health insurance. In 1996, approximately 70 percent of employees, including those in smaller firms that did offer insurance, were enrolled in ("take up") health insurance plans. Then, between 1996 and 2009, enrollment rates, when insurance was offered, fell approximately 10 percentage points. Declines occurred across all firm sizes, falling the most near the end of the 1990s before leveling off beginning in 2001. Declining employee enrollment rates are consistent with the higher co-premiums (Chart 11) and deductibles (Chart 12) being borne by workers.

\section{Commentary}

Given minor differences in enrollment rates by size of firms offering health insurance, the overall rate of insured workers is determined primarily by the likelihood that insurance is offered at all. In 2009, 99 percent of firms with more than 1,000 employees offered insurance, compared with just 33 percent of firms with fewer than 10 employees (see Chart 8). As enrollment rates in the two groups were the same in 2009 (63 percent, Chart 9), on average, a worker in a very large firm was three times more likely to be enrolled $(0.99 \times 0.63=62$ percent versus $0.33 \times 0.63=$ 21 percent) than a worker in a firm with fewer than 10 employees because most small firms do not offer health insurance. Those small firms that do offer insurance tend to enjoy higher margins and pay high wages (e.g., one- to five-person professional companies with highly compensated staff). It is primarily the latter that offer health insurance and have high take-up rates.

Many provisions in the ACA include financial incentives supporting employer-based coverage. Starting in 2014, the ACA will require employers with more than 200 employees to automatically enroll workers in their health insurance plans. Employees may then opt out of coverage, in which case the firm pays a penalty for workers enrolling in a subsidized health insurance exchange. While this provision will not necessarily alter the cost-sharing burdens in employer plans, its "automatic enrollment" feature may encourage workers to remain in their employer's plan. The penalty may also be enough to encourage some employers to offer insurance with the maximum allowed worker co-premiums.

There are several reasons why employees have been declining to enroll in employer-sponsored health insurance, as shown in the next four charts. 
Chart 9. Trend in the percentage of employees enrolled in private sector firms that offer health insurance, by firm size, 1996-2009

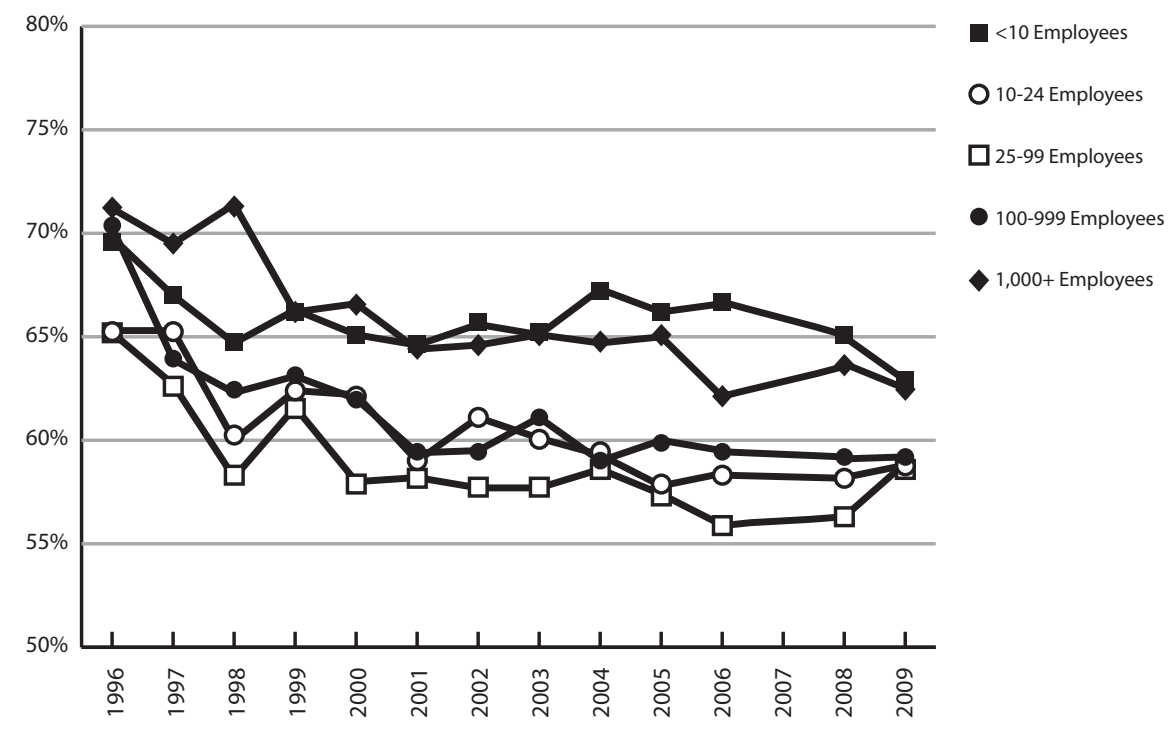

Note

Values interpolated for 2007

Source

Agency for Healthcare Research and Quality (2009). 


\section{Chart 10}

\section{Trends in Employee Premium Cost Sharing, by Firm Size, 1996-2009}

\section{The Numbers}

Employers can reduce their health costs by raising employees' portion of the premiums (co-premiums). Chart 10 shows the 1996-2009 trends in the percentage of single and family premiums contributed by employees in firms with more or fewer than 50 employees. From 1996 to 2002, the employee premium share stayed roughly constant in single-coverage plans and actually fell slightly for employees enrolled in family coverage plans. Then after 2003, the share of premiums contributed by employees rose 10-20 percent across firm sizes and plan types. By 2009, employees in small firms with fewer than 50 employees were paying 30 percent of the family premium, on average, when insurance was offered.

\section{Commentary}

Increases in employee premium cost sharing shortly after the year 2000 are consistent with the decrease in inflation-adjusted employer premium contributions seen earlier in Chart 5. Employees were paying 3 to 5 percentage points more for coverage in 2009 than in 2002, before taking into account the higher deductibles in plans that were offered (see Chart 12). To the extent that the ACA places an even larger financial strain on businesses, employee cost sharing will likely continue to rise. 
Chart 10. Trends in employee premium cost sharing, by firm size, 1996-2009

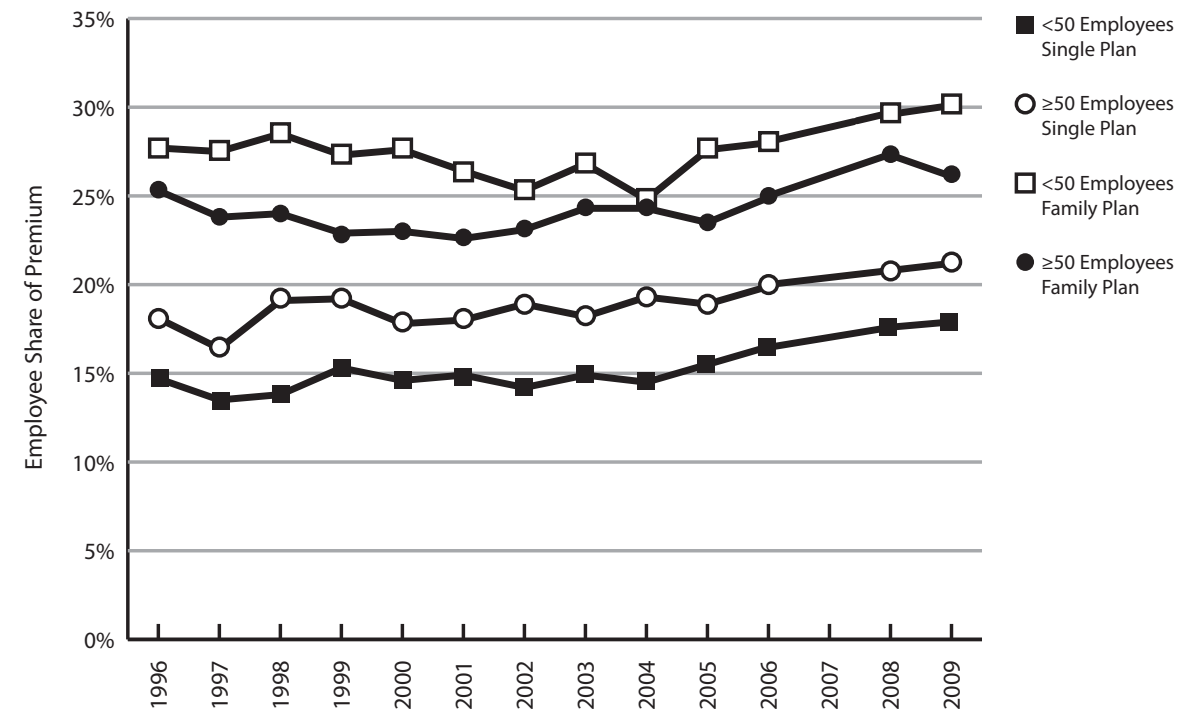

Note

Values interpolated for 2007

\section{Source}

Agency for Healthcare Research and Quality (2009). 


\section{Chart}

11 Trends in Average Monthly Employee Contributions to Health Insurance, by Coverage Type and Employment Status, 1999-2006

\section{The Numbers}

Workers increasingly are required to share the cost of business' health insurance premiums. Chart 11 shows the trend in employees' average monthly contribution, beginning in 1999. Contributions are in 2006 inflation-adjusted dollars and are stratified by employment status and whether coverage was for the family or individual worker. In 1999, employees with family coverage contributed between $\$ 200$ and $\$ 240$ on average per month toward the overall premium, depending on full- or part-time employment status. These contributions are roughly four times greater than for single worker coverage. Between 1999 and 2006, employees' portion of average monthly premiums for family coverage increased 44 percent for full-time workers (from \$204 to \$294) and 45 percent for parttime workers (from $\$ 233$ to $\$ 340$ ). Over the same time period, employers' premium costs grew more slowly for full-time workers (about 27 percent, see Chart 4). Moreover, in the 3 years after 2005, employers actually saw a reduction in their inflation-adjusted health premium burden (see Table 4).

The increase was considerably less for single coverage: 30 percent for full-time employees (from \$59 to $\$ 75$ ) and 24 percent for part-time employees (from $\$ 70$ to $\$ 87)$.

\section{Commentary}

As national health care costs and premiums continue to rise, employees are paying more for their coverage at work through a combination of slower wage increases and rising co-premiums. With wages up only 4 percent in real terms between 2000 and 2008 (Chart 5), fewer and fewer low-wage and part-time workers will be able to afford health insurance-even if offered by their employer. This has led to continuous erosion of health insurance coverage in American industry, as shown in Chart 9.

The ACA might raise employee premium burdens by raising overall premium costs. First, it mandates group plans to offer many preventive care benefits and places limits on out-of-pocket expenditures for plan beneficiaries. Second, the ACA also prohibits carveouts for preexisting conditions and allows dependents to remain on their family plans up to age 26 . All of these provisions should increase both family and single plan premiums, at least modestly. Employers will likely pass along almost all of the higher premium costs to workers in the form of lower wage increases and higher co-premiums. 
Chart 11. Trends in average monthly employee contributions to health insurance, by coverage type and employment status, 1999-2006

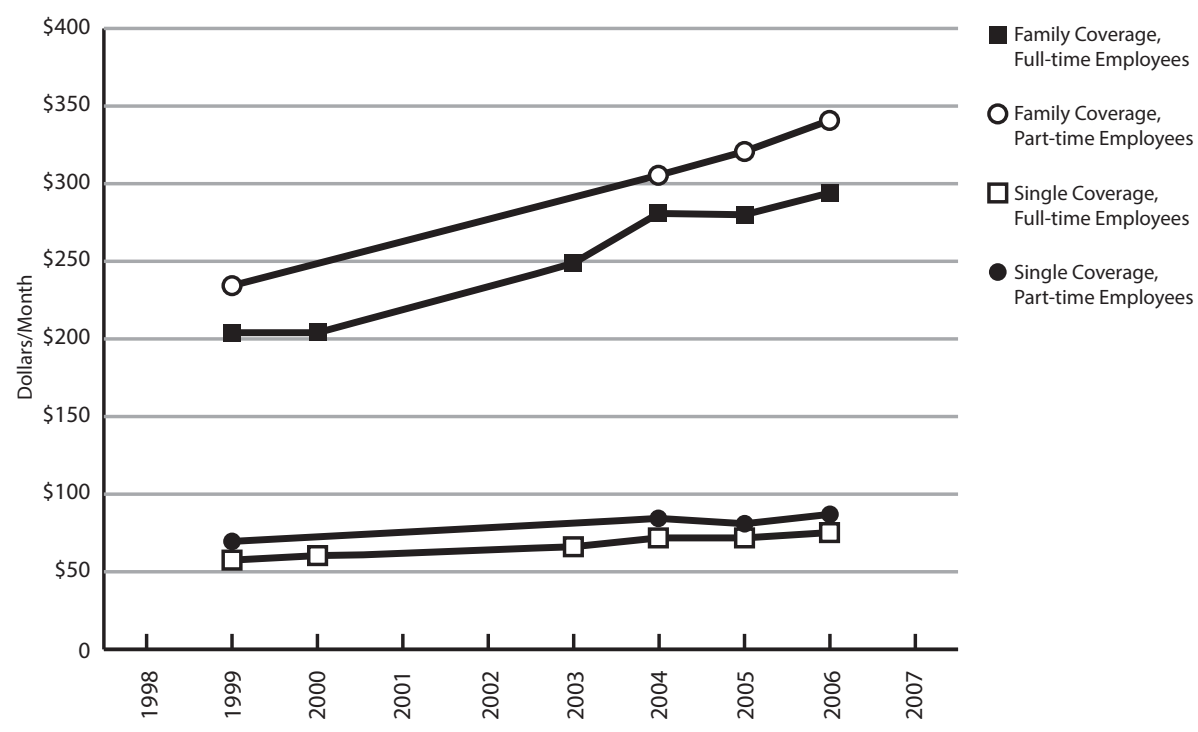

Notes

Nominal premiums were deflated by the 2006 CPI-U.

Values interpolated for missing years.

\section{Source}

Bureau of Labor Statistics Employee Benefits Survey, 1999-2006. 


\section{Chart 12 Trends in Employer Insurance Plan Deductibles, by Firm Size, 2002-2009}

\section{The Numbers}

Employers can reduce their premium costs and shift more to workers by simply reducing their share of the health premium. They can also shift insurance costs in a less direct fashion by offering plans with larger deductibles. Larger deductibles save insurers money and allow them to offer reduced premiums on highdeductible plans.

As shown in Chart 12, between 2002 and 2009, average plan deductibles, in 2009 dollars, increased by $55-78$ percent across plan types and firm size. By 2009, employees purchasing family health plans in small firms (fewer than 50 employees) had deductibles averaging $\$ 2,650$ compared with $\$ 1,640$ just 6 years earlier. In 2002, the family plan deductible in larger firms was about $\$ 1,000$. Just 6 years later, the deductible in larger firms had risen more than $\$ 600$. Single plan deductibles nearly doubled in small firms over 6 years.

\section{Commentary}

Four factors determine the advantages to an employee enrolling in an employer's plan: (1) the overall premium, (2) the co-premium paid by the worker, (3) the size of the plan's deductible, and (4) the worker's expected health care costs during the year. Plans with higher deductibles have lower premiums, which benefits healthy workers and their families because their expected health costs should not be burdensome out-of-pocket. Low-wage workers, too, benefit from high-deductible plans with lower monthly premiums. Less-healthy workers, however, may either have to accept greater financial risk with an employer's highdeductible plan or go without insurance coverage. 
Chart 12. Trends in employer insurance plan deductibles, by firm size, 2002-2009

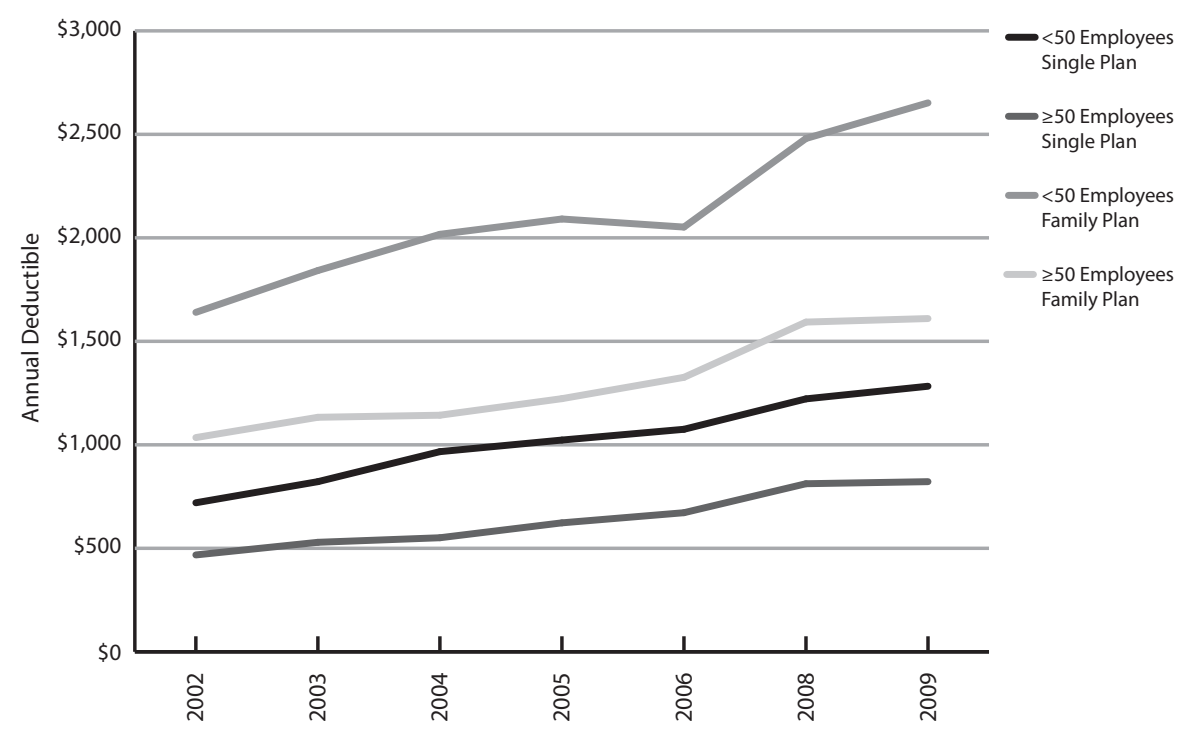

\section{Notes}

Deductibles in adjusted 2009 dollars. Source

Agency for Healthcare Research and Quality, 2002-2009 Medical

Expenditure Panel Survey-Insurance Component. 


\section{Chart \\ 13 Trend in the Percentage of Private Sector Firms That Offer Health Insurance to Retirees Under Age 65, by Firm Size, 1997-2009}

\section{The Numbers}

To minimize the effects of rising health premiums on bottom lines, another way that firms are reducing their health care burden is by discontinuing coverage of retirees under age 65 (Chart 13). The percentage of firms with 50 or more employees that offer health insurance to under-65 retirees fell from 40 percent in 1997 to 27 percent in 2001. After then holding fairly steady for the next few years, the percentage slipped again to 24 percent by 2009 , when three out of four large employers no longer offered health insurance to their early retirees (AHRQ, 2009). Small firms rarely offered health insurance to early retirees even in the 1990s. By 2001, essentially all small firms had eliminated the benefit. This is not surprising given that the majority of small firms do not offer health insurance even to current employees.

\section{Commentary}

Providing greater incentives for employers to extend health insurance coverage to their retirees has become especially important in light of recent proposals that would raise the Medicare eligibility age from 65 to 67. This threat to retirees of having to wait even longer for Medicare coverage underscores the importance of shoring up employer coverage for early retirees.

In an effort to address the gap in coverage for retirees under age 65, ACA has introduced a temporary (through 2013) reinsurance program for employers providing health insurance coverage to retirees over age 55 who are not eligible for Medicare. The program reimburses employers or insurers for 80 percent of retiree claims between $\$ 15,000$ and $\$ 90,000$. Starting in 2014, premium differentials by age will be restricted in the private insurance exchange markets, and sliding scale premium subsidies will be available to early retirees whose income is less than 400 percent of the federal poverty line. This reinsurance program will have little effect on small firms, but the intent of the program is to at least arrest the decline in employerbased retiree coverage in larger firms. 
Chart 13. Trend in the percentage of private sector firms that offer health insurance to retirees under age 65 , by firm size, 1997-2009

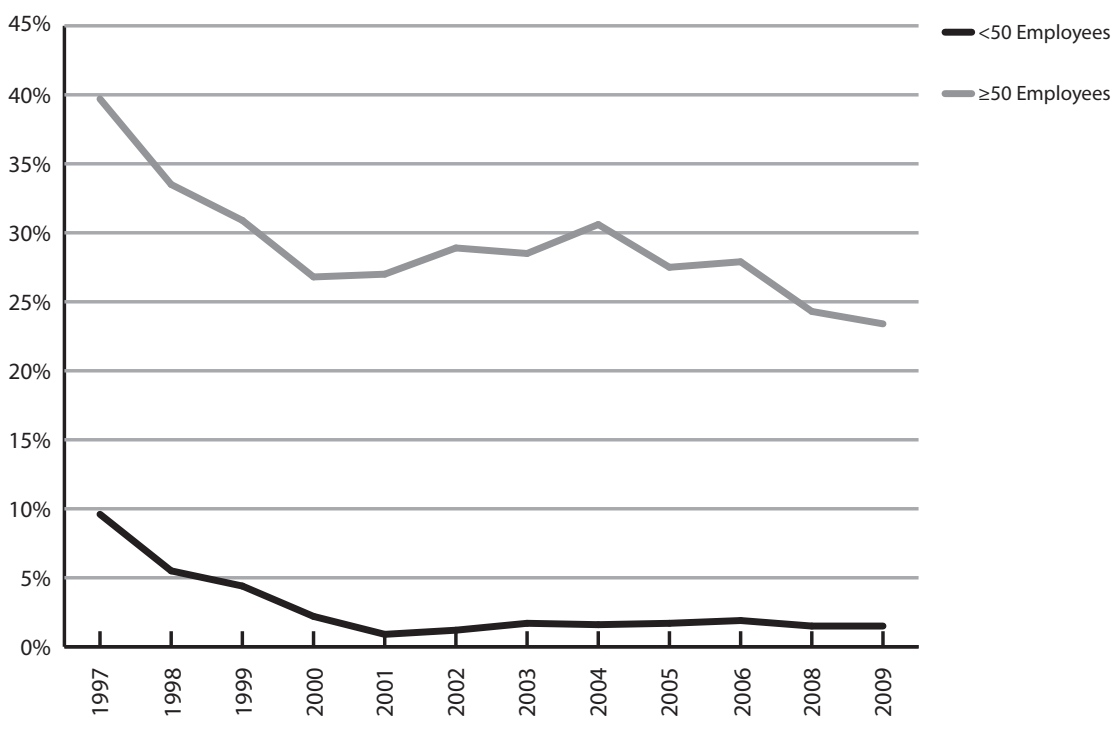

Sources

Agency for Healthcare Research and Quality (2009); Kaiser Family Foundation (2011, April 15; 2011);

Health Affairs (2010, November 23). 
Chart 14 Potential Uses of Excess Business Health Care Spending, \$92 billion in 2008

\section{The Numbers}

While businesses ultimately may bear none of the cost of insuring their workforce, their rising health care spending is a measure of the burden that is passed on to consumers or workers. "Excess" health care spending is the opportunity cost to businesses of unconstrained growth in the cost of health care. We define it in this chartbook as the growth of health care spending by businesses that exceeds the growth in gross domestic product (GDP). GDP is a measure of national income from wages, rents, interest, and profits that is available to pay for private or publicly provided health and other services. The opportunity costs of excess health spending are presented at a point in time and answer the question "What could the excess business health spending in 2008 have bought for businesses or employees?" If businesses' spending on health care services had grown only at the rate of GDP since 1990, in 2008 alone they would have saved an extra $\$ 92$ billion to spend in different ways.

For example, they could have used the $\$ 92$ billion to give each worker a 48 percent larger raise than he/she received in 2008, amounting to $\$ 852$ per year, on average (Chart 14). An extra $\$ 852$ would have felt significant to the many workers in the US whose average raise ( 3 percent) in 2008 did not keep pace with the increased cost of living (3.8 percent) (BEA, 2009).

At a time when America's economy is facing unprecedented global competition, had businesses decided to forego higher raises, with the $\$ 92$ billion they could have increased their research and development budget by 34 percent, creating new products and enhancing worker productivity.

Still another option, businesses could have used their $\$ 92$ billion in excess health spending to increase investment in equipment, structures, and software by 3 percent.

And had they chosen to do none of the above and retained the $\$ 92$ billion, pre-tax profits could have been 7 percent higher in 2008. This would have been especially welcome to businesses given the 26 percent decline in profits they experienced from 2007 to 2008.

\section{Commentary}

Rising health care costs raise labor costs for businesses, which are mostly passed on to workers in the form of lower wage increases. It does not appear that businesses have been particularly disadvantaged in international trade by rising health costs, at least relative to other industrialized economies, in part because of fluctuating exchange rates. However, to the extent that American workers do not, or cannot, accept lower wages in lieu of more comprehensive, and costly, health coverage, businesses are inclined to reduce their insurance coverage and seek cheaper labor overseas.

It is clear that the $\$ 92$ billion in savings in just 2008 greatly underestimates the full extent of the sacrifice in other investments or employee raises. Because of recent steps that US firms have taken to rein in their health care outlays, their $\$ 92$ billion in excess spending in 2008 is actually a fraction of the burden borne by households and government, as shown in later charts. 


\section{Chart 14. Potential uses of excess business health care spending, \$92 billion in 2008}

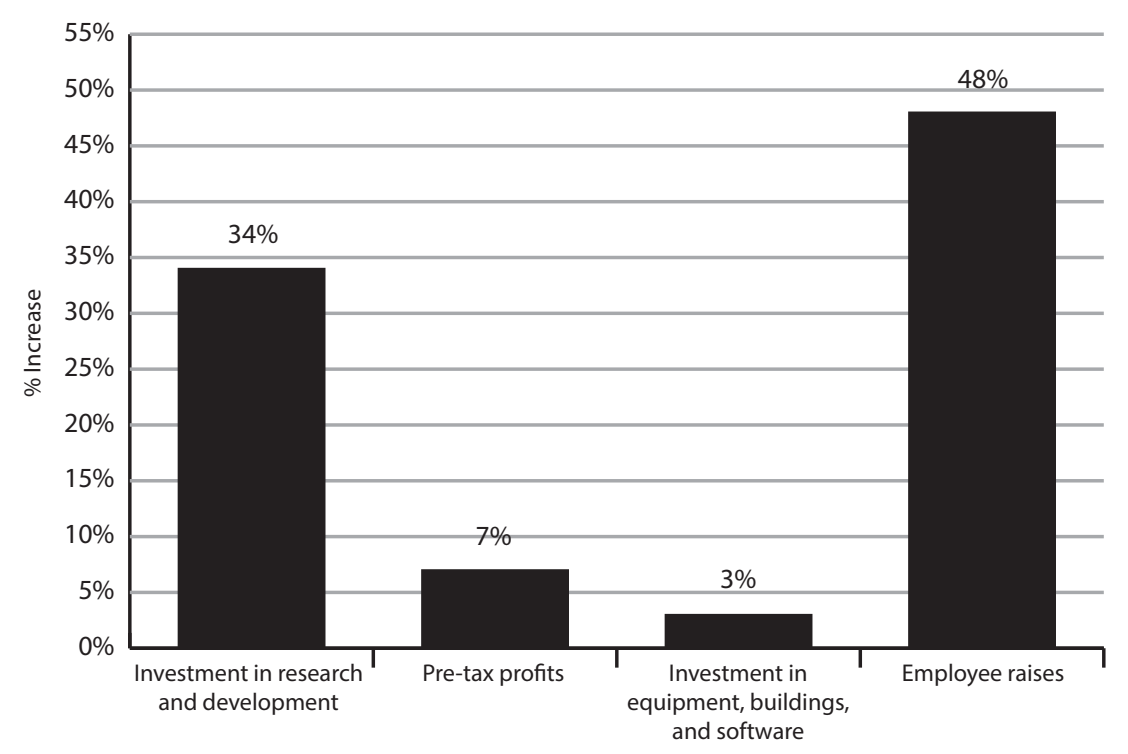

\section{Source}

Centers for Medicare \& Medicaid Services (2012), national health expenditure data. 
Page deliberately left blank. 


\section{PART III \\ Households: Financial Burden of Health Care \\ Spending}


- Out-of-pocket spending for services in 1987 was by far the largest of the three types of household health care expenditures at $\$ 110$ billion (58 percent), followed by employee and individual insurance premiums at $\$ 44$ billion (23 percent). Medicare taxes and premiums were the smallest of the three at $\$ 36$ billion (19 percent).

- Rates of increase in the three household spending components were also quite different. Out-ofpocket spending increased over 2.7 times its 1987 level by 2010, while premiums paid by workers and persons buying insurance in the individual insurance market grew much more quickly (6fold). Medicare taxes and premiums also grew over 4.5 -fold.

- Per capita deflated out-of-pocket personal health expenditures increased 53 percent from $\$ 635$ per person in 1965 to $\$ 970$ per person in 2010 . At the same time, deflated total health care spending per capita increased from $\$ 1,208$ to $\$ 7,074$, a 486 percent increase. The difference in these two growth rates produced a decline in the share that patients paid out of pocket for health care from 53 percent in 1965 to only 14 percent by 2010 , a $74 \%$ decline.
- Beginning 5 years after Medicare and Medicaid were enacted, out-of-pocket health care spending continued to decline from 33 percent of total health spending in 1970 to just 12 percent in 2008. The largest decline was for prescription drugs, which fell from 82 percent in 1970 to 21 percent in 2008, a decline of three-quarters. Households' out-of-pocket share for physician services fell from roughly 47 percent to 10 percent; dental care, from 91 percent in 1970 to 44 percent in 2008; and nursing home spending, from slightly over 50 percent to 27 percent. By contrast, households in 2008 paid less than 4 percent of the $\$ 718$ billion spent on hospital care in the United States compared with 10 percent in 1970 . The strong downward trend in households' out-ofpocket burden appears to have come to a halt in the late 1990s, with the notable exception of prescription drugs.

- The share of after-tax income spent by individuals directly on health services increased very modestly from 4.9 percent in 1984 to 5.2 percent in 2009.

- The elderly's financial burden out of income was more than twice that of persons aged 55-64 and over seven times that of persons under age 25.

- More than 50 percent of adults with low or moderate incomes reported having medical financial problems. Sixty-two percent of bankruptcy filings were for medical reasons, and the average medical debt at time of bankruptcy in 2007 was $\$ 17,943$. The medically uninsured had the greatest medical debt when filing for bankruptcy, almost $\$ 27,000$. Even an individual who had and retained private insurance at the onset of illness averaged nearly $\$ 18,000$ in medical debt when having to declare bankruptcy. 
- In 2010, 50 million (one in six) Americans were uninsured, an increase of 61 percent from 1986. All three major racial/ethnic groups experienced increases in the uninsured, led by Hispanics with a 2.5 -fold increase in their uninsured numbers due to population growth. Because blacks and Hispanics saw no decline in their already-high 1986 uninsured rates, the rising percentage of uninsured in America can be attributed primarily to rising uninsured rates among whites.

- Between 1990 and 2009, the share of the population covered by private employers peaked at 64 percent in 2000 before falling to 56 percent in 2009 as the economic recession began to take hold. On net between 1990 and 2009, the US population increased by 55 million, but the number of insured increased by only 39 million. Roughly one-third of the 55 million obtained insurance through their employer, but 8 million fewer Americans were able to directly purchase insurance in the private sector. Despite the fact that Medicare and Medicaid enrollees were just one-third the number of privately insured persons in 1990 (61 versus 182 million), the two government programs increased their coverage through 2009 by 32 million, a number 60 percent greater than the number of new persons covered by private insurance.
- Six in 10 workers in 2004 reportedly passed on a new job opportunity for health insurance cost reasons. Another 14 percent did not accept the new job because of a preexisting medical condition, and 11 percent said that the prospective employer offered insurance but with fewer benefits. Hence, one-quarter of job-locked workers were concerned about the financial risk of an uncovered illness or a medical condition.

- If the growth in household health care spending had been limited to the growth rate in GDP over the 1990-2008 period, households would have saved $\$ 80$ billion (an average of $\$ 698$ per household) in just the year 2008 alone to spend on other goods and services. Households could have invested the 2008 savings each year for 10 years in the Texas Promise Fund, thereby guaranteeing payment of one year of college for a child at the University of Texas. As another option, a family that invested $\$ 698$ each year (pretax) in a qualified retirement plan would have $\$ 9,223$ in 10 years for retirement, $\$ 24,247$ in 20 years, and $\$ 48,720$ in 30 years. 


\section{Chart 15 Trends in Household Health Care Spending, by Major Category, 1987-2010}

\section{The Numbers}

Household health care spending has increased markedly over the last 20 years or more (see Chart 2). Chart 15 decomposes household health care spending into its three major components over the 1987-2010 period: (1) employee and individual health insurance premiums, (2) Medicare Part A taxes and Part A and B professional premiums, and (3) out-of-pocket expenses on purchased services. Out-of-pocket spending includes direct individual payments for services not covered by insurance.

Out-of-pocket spending for services in 1987 was by far the largest of the three types of expenditures at $\$ 110$ billion (58 percent), followed by employee and individual insurance premiums at $\$ 4$ billion (23 percent). Medicare taxes and premiums were the smallest of the three at $\$ 36$ billion (19 percent).

Rates of increase in the three components also were quite different. Out-of-pocket spending increased to $\$ 300$ billion by 2010 , over 2.7 times its 1987 figure, yet the premiums of workers and persons buying insurance in the individual insurance market grew much faster (6-fold). By 2010, co-premiums for employees plus premiums in the individual insurance market amounted to $\$ 263$ billion, or 88 percent of household out-of-pocket spending, up from 40 percent in 1987. Medicare taxes and premiums also grew over 4.5-fold, reaching $\$ 163$ billion in 2010. Consequently, by 2010, out-of-pocket expenses were only 41 percent of all household health care spending. Employer and individual premiums had risen from 23 percent to 36 percent.

\section{Commentary}

Often, out-of-pocket expenses are used as a proxy for the household's financial burden of burgeoning health care spending. Chart 15, though, reminds us that direct out-of-pocket expenses no longer represent the majority of household health spending. Nevertheless, a tripling of out-of-pocket spending in just 20 years (Chart 15) has crippling effects on many budgets after what households have already put into the system in the way of insurance premiums and Medicare taxes. 
Chart 15. Trends in household health care spending, by major category, 1987-2010

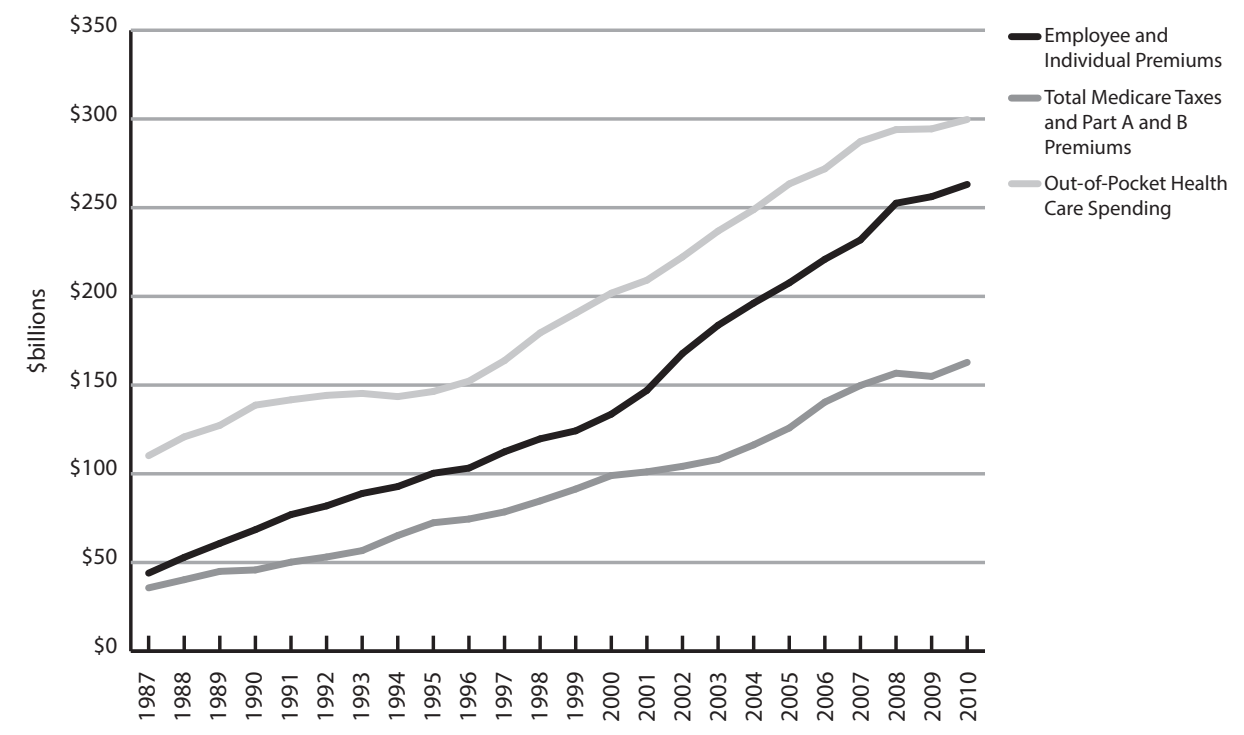

\section{Notes}

Spending unadjusted for inflation.

\section{Source}

Centers for Medicare \& Medicaid Services (2012), national health expenditure data. 


\section{Chart}

17 Trends in Per Capita Out-of-Pocket Health Care Spending, in Total and As a Share of Total Spending, 1965-2010

\section{The Numbers}

Chart 16 shows trends in inflation-adjusted per capita out-of-pocket medical spending from 1965 to 2010 . Per capita deflated total personal health spending out-ofpocket (top graph) increased 53 percent from $\$ 635$ per person in 1965 to $\$ 970$ per person in 2010 . This trend is the product of the trend in total personal health care spending per capita and the share of spending outof-pocket. Personal health care spending per capita (middle graph), adjusted for inflation, increased from $\$ 1,208$ to $\$ 7,074$, a 486 percent increase. Meanwhile, the out-of-pocket share fell from a high of 53 percent in 1965 to only 14 percent by 2010 , a 74 percent decline.

The out-of-pocket burden appears to have gone through six phases. From 1965 to 1975, per capita real out-of-pocket spending rose just $\$ 72$ (see Table 16) from $\$ 635$ to $\$ 707$. This was due to a 5.6 percent annual increase in real health spending per year that was partially offset by a 2 percentage point decline (or 20 points over 10 years) in the out-of-pocket share per year.

From 1975 through 1982, the out-of-pocket burden hardly increased at all (\$7 in total) as real per capita spending slowed considerably. From 1982 to 1990, the out-of-pocket burden rose $\$ 218$, a 30 percent increase as spending growth accelerated while the out-ofpocket share declined more slowly. Between 1990 and 1996, the out-of-pocket burden reversed direction and declined by $\$ 142$ due primarily to much slower overall spending growth. Between 1996 and 2007, the out-of-pocket burden reversed course again and rose $\$ 231$ as health care spending accelerated without any meaningful decline in patients' out-of-pocket share (-0.1 percent per year). Finally, between 2007 and 2010, the out-of-pocket burden turned negative once again through a combination of slower spending growth and a slightly faster decline in the out-of-pocket share.

\section{Commentary}

There is no question that third-party insurers have sheltered patients from the great majority of cost inflation that has taken place in the health care sector. The dramatic decline in out-of-pocket payments at point of service explains a great deal of the growth in health care spending over the last 40 years. Insured patients and their physicians have become increasingly insensitive, financially, to the rise in health sector prices and the cost of services (Newhouse, 1993, chapter 11). Moreover, for many years insurers paid

Table 16. Trend in per capita out-of-pocket health care burden, 1965-2010

\begin{tabular}{lccc}
\hline Year & $\begin{array}{c}\text { Change in Per Capita Out-of-Pocket } \\
\text { Spending (In Real Dollars) }\end{array}$ & $\begin{array}{c}\text { \% Change Per Year in Per Capita } \\
\text { Spending (In Real Dollars) }\end{array}$ & $\begin{array}{c}\text { \% Change Per Year in } \\
\text { Out-of-Pocket Share }\end{array}$ \\
\hline 1965 & - & - & - \\
\hline 1975 & $\$ 72$ & $5.6 \%$ & $-2.0 \%$ \\
\hline 1982 & $\$ 7$ & $3.7 \%$ & $-1.0 \%$ \\
\hline 1990 & $\$ 218$ & $4.9 \%$ & $-0.4 \%$ \\
\hline 1996 & $-\$ 142$ & $2.4 \%$ & $-1.0 \%$ \\
\hline 2007 & $\$ 231$ & $3.2 \%$ & $-0.1 \%$ \\
\hline 2010 & $-\$ 51$ & $1.3 \%$ & $-0.4 \%$ \\
\hline
\end{tabular}

\section{Note}

Spending deflated by CPI in 2009 dollars.

Source

Centers for Medicare \& Medicaid Services, national health expenditure data. 
Chart 16. Trends in per capita out-of-pocket health care spending, in total and as a share of total spending, 1965-2010
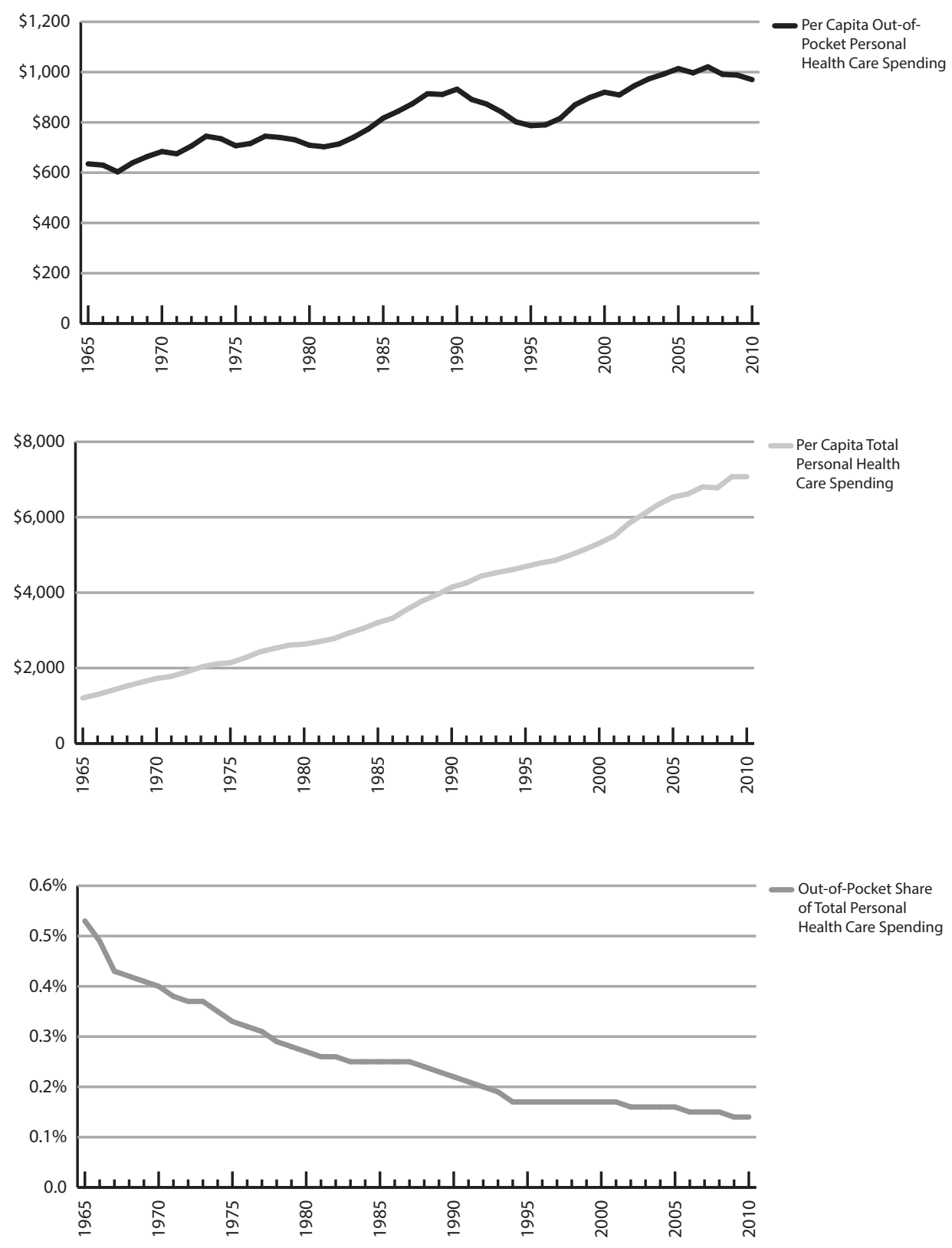

Note

Spending deflated by CPI in 2009 dollars.

Sources

Centers for Medicare \& Medicaid Services, national health expenditure data. 


\section{Chart 16 Trends in Per Capita Out-of-Pocket Health Care Spending, in Total and 16 As a Share of Total Spending, 1965-2010 (continued)}

based on provider costs or on a percentage of charges. This encouraged providers to provide new, more costly services. An ever-expanding role of public Medicare and Medicaid insurance coverage, with their minimal patient financial burden, reinforced the decline in households' out-of-pocket share of the spending burden.

The 1980s were a watershed period in the health care industry, primarily due to more aggressive cost containment by the federal government. Medicare hospital payments were bundled by diagnosis and paid on a fixed prospective basis. Bundled hospital payment triggered a shift to outpatient care with shallower insurance coverage. Private insurers responded to provider cost-shifting in the 1980s with a wave of managed care plans in the 1990s that moderated the growth in health care spending-particularly in ambulatory physician services. Medicare also became more active in promoting managed care for its beneficiaries. In the early 1990s, states also rapidly expanded enrollment in their Medicaid programs, which lowered out-of-pocket payments of those previously uninsured.
The fact that the out-of-pocket burden has leveled off over the last 6-7 years, at least as a share of health spending, indicates recent limitations in the ability of public and private payers to continue to pay more for nursing home, dental, physician, and other services. America's health insurers may be at a crossroads. Either out-of-pocket spending will continue to rise as private insurers continue to pass on their costs to subscribers, or the government will take on an even greater burden of health care spending - as legislated in the major expansion of Medicaid eligibility under the ACA.

Congress, in the ACA, recognized the seriousness of spiraling health care costs, especially for families, by placing a cap on annual out-of-pocket costs and removing any lifetime coverage limits from health insurance plans. Coupled with the major expansion in Medicaid eligibility from 100 percent to 133 percent of the poverty line, these provisions should slow, and possibly reverse, the growth of household out-ofpocket health expenditures. Whether this expansion will further reduce the out-of-pocket burden on the whole population depends on how aggressive private insurers and employers will be in shifting health care costs to individuals and households. 


\section{Chart 77 Trends in Out-of-Pocket Spending as a Share of Total Health Care Spending, by Major Service, 1970-2008}

\section{The Numbers}

The financial burden of health care spending on households can be separated into direct out-of-pocket expenses and insurance premiums, but only the former can be allocated to specific health care providers. Chart 17 shows the 1970-2008 trends in household out-of-pocket spending as a share of all US health care spending as well as for five major health services.

Out-of-pocket health care spending, despite growing rapidly (see Chart 15), actually declined from 33 percent of total health spending in 1970 to just 12 percent in 2008 (Chart 17). All major services also showed declines in out-of-pocket spending shares but at different rates. The largest decline was for prescription drugs, where the direct patient burden fell from 82 percent in 1970 to 21 percent in 2008, a decline of three-quarters. Households' out-of-pocket share for physician services fell even faster, from roughly 47 percent to 10 percent, nearly a four-fifths decline. There was also a major decline in the share paid by households for dental care, from 91 percent in 1970 to 44 percent in 2008. Nursing home spending by individuals fell from slightly over 50 percent to 27 percent. In contrast, households' direct financial burden for hospital care was low even in 1970. By 2008, households paid less than 4 percent of the $\$ 718$ billion spent on hospital care in the United States.

The strong downward trend in households' out-ofpocket burden appears to have come to a halt in the late 1990s, with the notable exception of prescription drugs. As many new brand drugs entered the market, insurers included them in their coverages, at very high cost. In addition, a further downward shift in out-ofpocket payments can be seen in 2006, when Medicare expanded its program coverage to include outpatient prescription drugs.

\section{Commentary}

The spending trends observed in Chart 17 are a product of more general demographic trends and the responses of insurers to rising health outlays. First is the growing elderly population who require more of all health services, particularly nursing care and prescription drugs to treat chronic conditions. Second, expensive hospital care was the first health service to be covered by insurers. Third, as care shifted to nonhospital providers, Americans demanded broader and deeper health insurance coverage. 
Chart 17. Trends in out-of-pocket spending as a share of total health care spending, by major service, 1970-2008

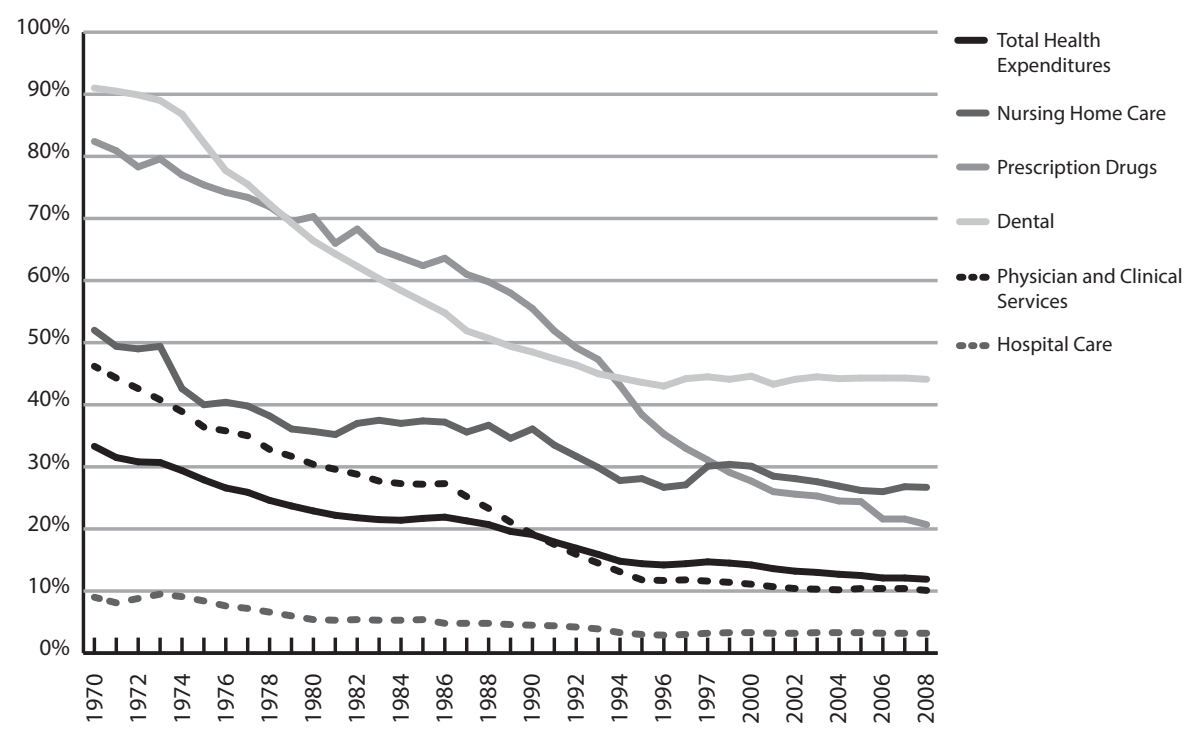

\section{Source}

Centers for Medicare \& Medicaid Services, national health expenditure data. 
Chart

18 Out-of-Pocket Health Care Spending as a Percentage of Income, by Age Group, 2009

\section{The Numbers}

The burden of health care spending has risen over time for the population as a whole, but how have households headed by individuals of varying ages been affected? Chart 18 stratifies 2009 out-of-pocket health spending by individuals as a share of their after-tax income, by age group. Household out-of-pocket health care expenditures represented 5.15 percent of all after-tax income. The proportion of income devoted out-of-pocket to health care rises consistently with age and accelerates after age 65. Individuals under age 25 spent 2.65 percent of their income on health care $(\$ 676 / \$ 25,522)$. By ages 55 to 64 , individuals devoted more than twice as much of their income to out-ofpocket health payments $(\$ 3,895 / \$ 67,586)$ despite the fact that their income was 2.6 times that of persons under age 25 . Persons over age 65 spent more than 12 percent of their income out-of-pocket on health care $(\$ 4,846 / \$ 39,054)$. Although covered by Medicare, the elderly spent an average of over $\$ 1,000$ (25 percent) more per capita on health care out-of-pocket than did persons aged 55-64, and their income was more than 40 percent lower. In sum, the elderly's financial burden for health care was more than twice that of persons aged 55-64 and over seven times that of persons under age 25 .

This pattern has been consistent over three decades. Overall, the share of total income spent by individuals directly on health services increased very modestly from 4.5 percent of income in 1984 to 6.4 percent in 2009 (BLS, n.d., 2011).

\section{Commentary}

Because older people are a growing proportion of the population and have the highest share of income devoted to health care services, the overall percentage of Americans' personal income devoted to direct health care, after insurer payments, will continue to increase in the absence of major reforms. The minimal financial burden of health care on younger people as reflected in Chart 18, however, understates the effect of rising health care spending on a vulnerable minority. While most of the population under age 35 have essentially no health care outlays, the few under age 35 with serious health issues must spend substantially more of their limited income out-of-pocket than the $2-3$ percent implied in Chart 18. Also, out-of-pocket expenditures by the younger population do not account for the health-related Medicare taxes taken out of their wages or federal income taxes paid to support the Medicare program. Hence, while it might appear that only the elderly have a strong interest in cost containment to reduce their out-of-pocket spending, the younger population does as well, especially if Medicare coverage may be limited by the time they retire.

This said, it is remarkable how large a percentage of older persons' income is devoted to health services, given their extensive Medicare and supplemental Medigap coverage. For those without supplemental insurance, Medicare requires a 20 percent co-pay on professional services, requires that beneficiaries pay a deductible covering the first day in a hospital, and covers only a portion of prescription costs of highcost users. Nor does the 12.4 percent burden include the premiums they pay if they have supplemental insurance coverage. It is not true, as some might believe, that Medicare guarantees universal health coverage, with all care being free. Even with substantial public insurance, the elderly still pay a substantially greater fraction of their income on health care.

To ease the financial burden of health care on the elderly, it has been suggested that their monthly Social Security payments be updated by the Consumer Price Index for the Elderly (CPI-E) because it better reflects their spending habits (more on medical care, less on education) than the CPI for the overall population. This index would place a weight of 12 percent on health care spending, resulting in larger updates in monthly retirement payments. Alternatively, health reform with effective cost containment could mitigate 
the consequences by using the current Consumer Price Index for Urban Wage Earners and Clerical Workers (CPI-W), which underweights health care spending for the elderly. A counter-argument to switching from the CPI-W to the CPI-E is the sizable, and growing, subsidy enjoyed by Medicare beneficiaries on their health care spending (discussed later, in Chart 27). Another way to ease the financial burden on the elderly is to set a catastrophic limit on out-of-pocket expenditures.

\section{Chart 18. Out-of-pocket health care spending as a percentage of income, by age group, 2009}

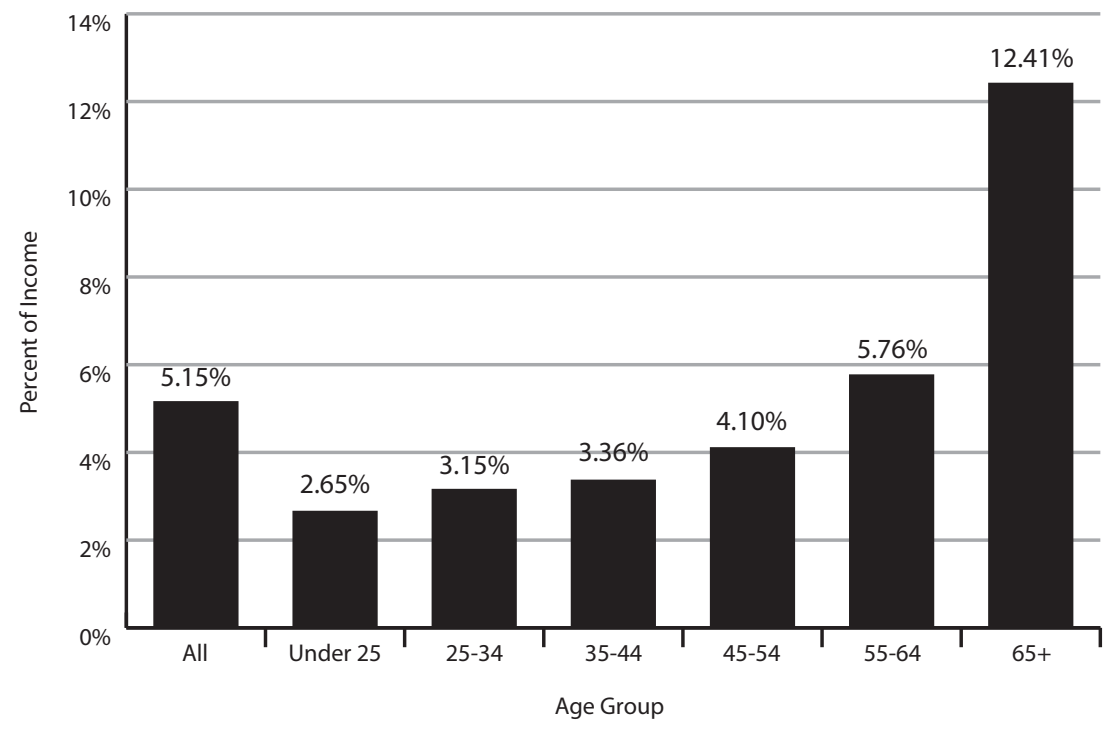

Note

Income after taxes.

Source

Bureau of Labor Statistics (2010), Consumer Expenditure Survey. 


\section{Chart 19 Percentage of Adults Aged 19-64 with Medical Bill or Accrued Medical Debt Problems, by Income Level, 2007}

\section{The Numbers}

A 2007 study by the Commonwealth Fund (Doty, Collins, Rustgi, \& Kriss, 2008) found that 41 percent of the non-elderly population (or 72 million people) and 19 percent of the elderly had problems with medical bills, accrued debt, or both. Chart 19 shows the percentage of 19- to 64-year-old adults who reported problems paying their medical bills or had burdensome accrued medical debt in 2007, whether or not they officially declared bankruptcy. The data are presented by level of income. Medical bill or debt problems for a given income category depend on (1) the probability of being sick, multiplied by (2) average out-of-pocket medical costs in treating an illness.

About 40 percent of adults reported having medical bill or debt problems in 2007. Furthermore, more than 50 percent of adults with low or moderate incomes reported having medical financial problems. This percentage falls to 39 percent when income is between $\$ 40,000$ and $\$ 60,000$. Still, even one-quarter of adults with high incomes, above $\$ 60,000$, reported having medical bill or debt problems.

\section{Commentary}

As incomes for the non-elderly middle class stagnate and health care costs continue to rise, problems with medical debt are becoming more common. Even with extensive insurance coverage, minor health problems can be financially devastating. This is particularly true for lower-income families, who are more likely to be uninsured or underinsured-either because the employer offers limited coverage or because employees are forced to choose plans with high deductibles and less comprehensive benefits in exchange for lower premiums. Lower-income families that are financially ineligible for their state Medicaid programs are the most vulnerable to unexpected medical bills. Ultimately, under stress of rising medical bills and debt, families may resort to bankruptcy, as shown in the next chart. 
Chart 19. Percentage of adults aged 19-64 with medical bill or accrued medical debt problems, by income level, 2007

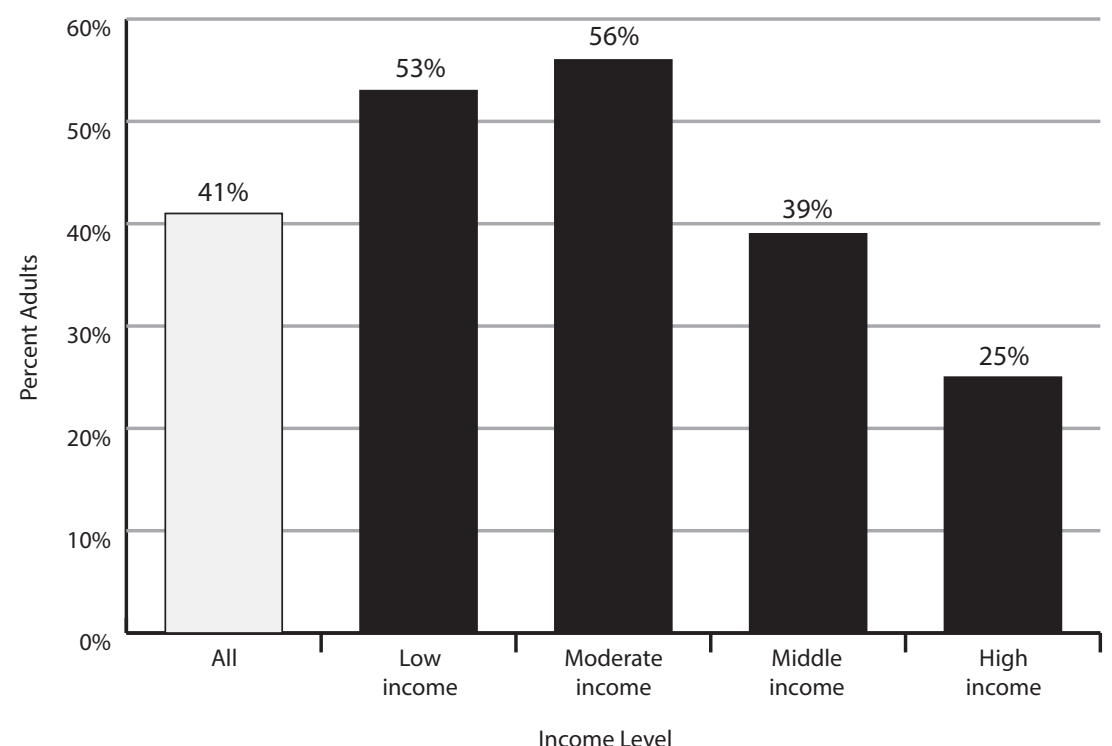

\section{Note}

Low income is defined as less than $\$ 20,000$; moderate income, $\$ 30,000-\$ 39,999 ;$ middle income, $\$ 40,000-\$ 59,999$; and high income $\$ 60,000$ or more per year.

\section{Source}

Doty et al. (2008). 
Chart 21 Medical Debt at Bankruptcy Filing, by Health Insurance Status, 2007

\section{The Numbers}

Relatively minor financial burdens borne by individuals under age 65 (see Chart 19) mask far greater burdens for a small percentage of Americans. Even with insurance, an individual's inadequate coverage can lead to substantial out-of-pocket expenditures. Most individual and employer plans limit coverage in various ways. For example, medical benefits may be capped at just a few thousand dollars a year or may omit prescription drug coverage. Chart 20 reports the average medical debt for households that declared bankruptcy in 2007. Filers are categorized by type of insurance coverage. The results are based on a national survey of individuals who filed for bankruptcy and cited medical debt as a major reason.

Conservatively, 62 percent of bankruptcy filings were for medical reasons (Himmelstein, Thorne, Warren, \& Woolhandler, 2009). The average medical debt at time of bankruptcy in 2007 was $\$ 17,943$. As expected, medically uninsured individuals had the greatest medical debt when filing for bankruptcy, almost $\$ 27,000$, while individuals with VA or military coverage had only $\$ 6,500$, on average, in medical debt. Even if an individual had private insurance at the onset of his or her illness and retained it until bankruptcy, he or she still averaged nearly $\$ 18,000$ in medical debt. Those who eventually lost their insurance incurred several thousand dollars more debt. Individuals covered by Medicare or Medicaid who declared bankruptcy also show surprisingly high medical indebtedness ( $\$ 12,000$ to $\$ 14,600)$.

\section{Commentary}

A complex relationship exists between health insurance and the size of medical debt at bankruptcy. Higher income and health insurance both reduce the likelihood of declaring bankruptcy, while illness raises the likelihood. Low-wage workers have little protection against illness and loss of work. Those who are sick and do not have health insurance are particularly vulnerable to crushing debt. Even with insurance, sickness can force lower-income individuals into bankruptcy, as evidenced by people eligible for Medicare and Medicaid declaring bankruptcy.

For younger cohorts, medical expenditures vary considerably depending on whether an individual or family has health insurance and, even if insured, whether they are fully or partially insured. Gaps in medical coverage raise the likelihood that a family will be overwhelmed by its medical bills and file for personal bankruptcy (Collins, Kriss, Doty \& Rustgi, 2008). Continuous, comprehensive health insurance coverage would help avoid burdensome medical debt and bankruptcy.

Several provisions in the ACA should help curb the incidence and magnitude of medical debt and subsequent bankruptcy filings. Under the ACA, "limited benefit" plans with inadequate coverage will not be allowed. Plans will not be able to deny coverage for a preexisting condition, nor will plans be able to impose a lifetime limit on benefits. The subsidized public insurance exchanges should be an affordable option for people who currently cannot afford comprehensive health insurance (or any health insurance at all). Medicaid will be expanded to cover millions of households near the poverty threshold. All of these provisions should lessen the problem of medical debt and resulting bankruptcies. If the ACA works as planned, burdensome medical bills should be one of the more sensitive indicators of program success. 
Chart 20. Medical debt at bankruptcy filing, by health insurance status, 2007

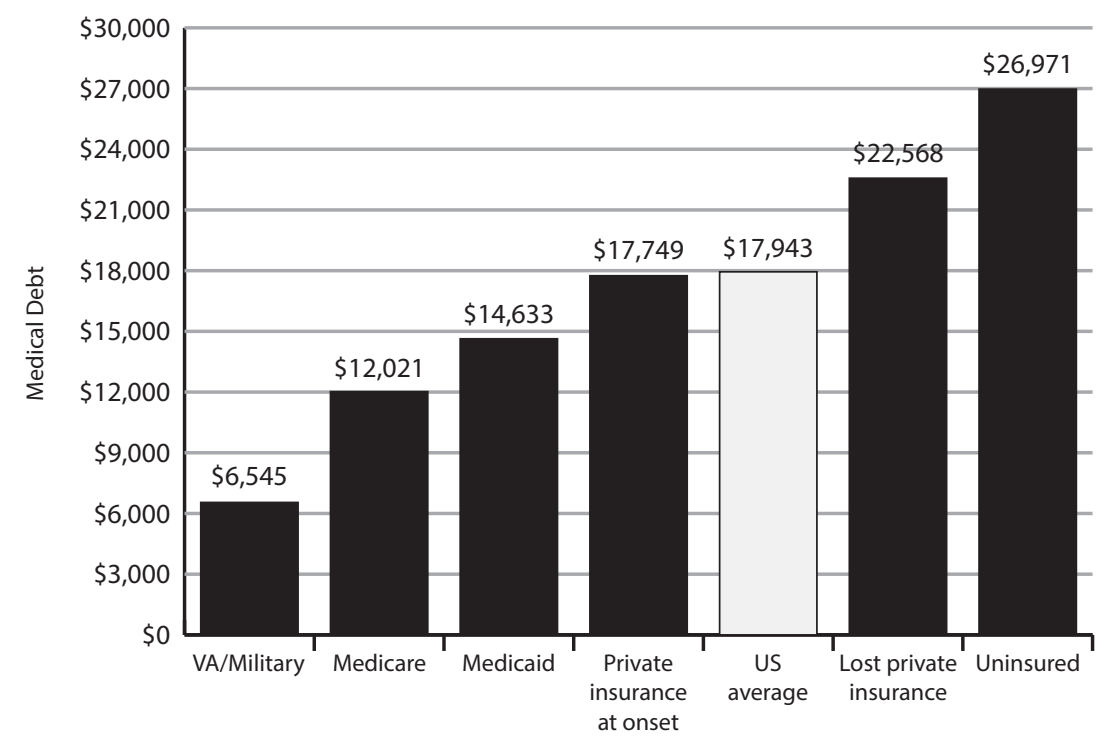

Health Insurance Status

Notes

Information is based on bankruptcy filings and interviews with families filing for bankruptcy. Private insurance at onset indicates that the individual had and retained coverage after the onset of illness.

Source

Himmelstein et al. (2009). 


\section{Chart}

\section{Trends in the Number of Uninsured, by Race and Ethnicity, 1986-2010}

\section{The Numbers}

Chart 21 shows the 25-year trend in the total number of uninsured in America as well as for blacks and whites alone (not mixed race) and for Hispanics of any race. In 2010, 49.9 million Americans were uninsured, an increase of 61 percent over the 31.0 million uninsured in 1986. All three major racial/ethnic groups experienced increases, led by Hispanics with a 2.5 -fold increase since 1986.

Adjusting for population growth presents a different picture. The percentage of white-only Americans (excluding mixed races) without insurance doubled from 1986 to 2010 (Table 21). Because blacks and Hispanics saw no decline in their already-high uninsured rates, the overall rising percentage of uninsured in America can be attributed to rising rates of uninsured whites.

Three periods are apparent in the growth of the uninsured. Their numbers rose consistently for the first decade after 1986, including a sharp increase in 1991 when the unemployment rate jumped from 5.6 percent to 6.8 percent (BLS, 2012). Then a short 3-year period after 1997 saw a decline in the number of uninsured as the unemployment rate fell sharply for a few years. Since 2000, the number of uninsured Americans has trended upward again, rising by over 13 million to 49.9 million through 2010 . The noticeable jump in the 2008-2010 period that added over 5 million people to the rolls of uninsured is also explained in fair part by the rise in the unemployment rate from 5.8 percent to 9.6 percent (US Census Bureau, 2011).

\section{Commentary}

The number and percentage of Americans without insurance has continued to rise. Lack of health insurance has always been a greater burden on minorities, with uninsured rates three to four times those of whites. But it is the decline in coverage among whites that has been driving up the share of uninsured in America.

Without health insurance, people bear two potential burdens. The first burden is the mental strain of being uninsured with the risk of incurring financially catastrophic medical costs in the event of an illness or accident. The second burden is having to declare bankruptcy due to high medical bills (see Chart 20).

Uninsured rates are sensitive to the business cycle. Because non-elderly individuals rely so heavily on their employer for health insurance-86.4 percent of privately insured persons have coverage at their or their spouse's workplace (US Census Bureau, 2011, Table HIA-1) - any economic downturn has a compound effect on workers. Should they become unemployed, not only do they suffer a loss of income, they often lose their health insurance coverage as well. This leaves them particularly vulnerable to financial catastrophe. This was not always the case when health care costs were more manageable out-of-pocket. As disappointing as the trend in health insurance coverage is, it could have been much worse if not for government intervention, as shown in the next chart. 
Table 21. Percentage uninsured, by race and ethnicity, 1986-2010

\begin{tabular}{lcccc}
\hline Year & Blacks Alone & Hispanic, Any Race & Whites Alone & All Races \\
\hline 1986 & $20 \%$ & $31 \%$ & $7 \%$ & $13 \%$ \\
\hline 1990 & $21 \%$ & $32 \%$ & $7 \%$ & $14 \%$ \\
\hline 2000 & $19 \%$ & $31 \%$ & $11 \%$ & $13 \%$ \\
\hline 2010 & $21 \%$ & $31 \%$ & $14 \%$ & $16 \%$ \\
\hline
\end{tabular}

\section{Notes}

Black and white percentages exclude persons of mixed races; Hispanic percentage includes mixed races; All Races percentage not based on race or ethnicity.

\section{Source}

US Census Bureau (2011), Current Population Survey.

\section{Chart 21. Trends in the number of uninsured, by race and ethnicity, 1986-2010}

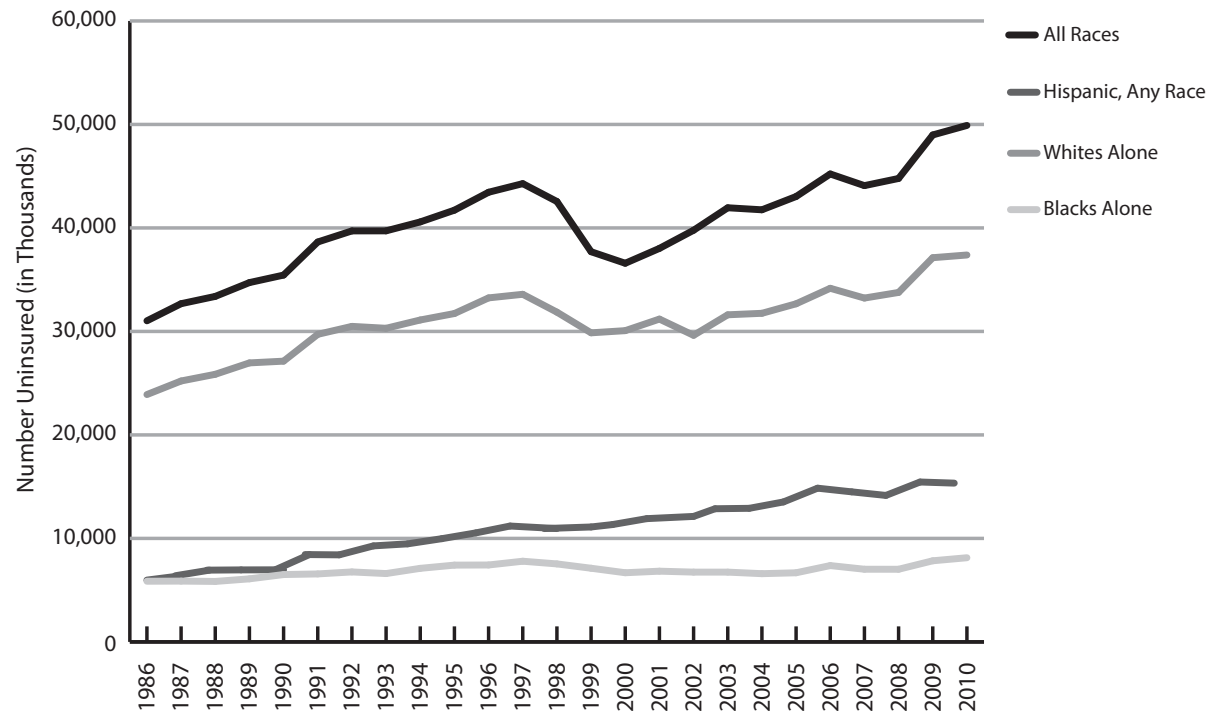

\section{Note}

1993: individuals 18 and older; 1998 : individuals 20 and older; all other years: individuals 21 and older. Totals for blacks, Hispanics, and whites do not sum to total uninsured for All Races due to minor double-counting among Hispanics and unreported races.

\section{Source}

US Census Bureau (2011), Current Population Survey; Bureau of Labor Statistics (2012) 
Chart

Trends in the Percentage of the US Population Insured by Private Employers, Medicare, and Medicaid, 1990-2009

\section{The Numbers}

As the costs of health care rise for employers, workers, and persons buying their health insurance in the individual market, the ability of the private sector to insure all of the new entrants to the workforce has been under increased strain. Chart 22 compares the trend in the US populations covered by either private employers in the workplace or direct purchase with the growth in the percentage covered in the two main government programs, Medicare and Medicaid.

Between 1990 and 2009, the share of the population covered by private employers rose to a peak of 64.2 percent in 2000 before falling consistently to 55.8 percent in 2009 as the economic recession began to take hold (US Census Bureau, 2011). Private coverage also fell in the early 1990s as unemployment rose, but then made a strong recovery through the later 1990s with strong economic growth before suffering again from the recession of 2000 .

The two public insurance programs have moved in the opposite direction. With the aging of the population, the Medicare program has seen its responsibility for insuring Americans rise from 13 percent of the US population in 1990 to 14.3 percent in 2009, or 11.2 million persons. Its coverage is fairly insensitive to the business cycle. The Medicaid program for the poor increased its coverage from 9.7 percent to 15.7 percent of the US population, with 23.5 million more persons enrolled. As expected, Medicaid coverage over time moved in opposition to private coverage, falling in the later 1990s with strong economic growth and rising rapidly as private insurance receded.

On net, between 1990 and 2009, the US population increased by 55 million, but only 39 million persons were able to get health insurance (US Census Bureau, selected years). Roughly 20 million of 55 million (about one-third) obtained insurance through their employer, but approximately 8 million fewer were able to directly purchase insurance in the private sector. Despite the fact that government-covered Medicare and Medicaid enrollees were just one-third the number of privately insured persons in 1990 (61 million versus 182 million), the government increased its coverage by 2009 by 32 million, a number 60 percent greater than new persons covered by private insurance.

Table 22 shows the rates of growth in the three major health insurance sectors (private, Medicare, and Medicaid). In the table, unlike Chart 22, private insurance includes both employer-based and direct purchase plans.

Over the entire 1990-2009 period, the US population increased 22 percent while the number of insured rose only 18 percent, resulting in 46 percent growth in the number of uninsured. Private insurance coverage, increasing only 7 percent, was unable to keep up with population growth. Both Medicare and Medicaid picked up some of the difference by increasing their coverage by about 35 percent and 97 percent, respectively.

The last decade of the 20th century generally provided a favorable economic climate with a relatively modest increase (11 percent) in the share of the population who were uninsured. The large private sector was still expanding coverage to more people. The first decade of the 21 st century presented a more negative picture. Growth in the privately insured actually turned negative. Medicare continued to pick up more persons as the population aged, and Medicaid expanded coverage by 62 percent. Yet this was not enough to completely offset the shrinking private sector. As a result, the number of uninsured rose 32 percent. 


\section{Commentary}

Over the last two decades, the private insurance sector has not been able to keep pace with the growing American population. Insurance through employment has risen modestly, while the unemployed have not been able to afford, or have been denied, private coverage. A percentage, possibly as low as 15 percent, of the decline in private insurance might be due to Medicaid expansions that encourage employers to drop coverage, the so-called crowd-out effect (Cutler \& Gruber, 1996). Aging into Medicare coverage also explains some of the decline in private coverage. But rising employer premiums and employee copremiums, higher deductibles, more part-time workers, and reductions in retiree coverage are also playing a significant role in the relative decline in the number privately insured. These secular trends are greatly exacerbated in times of recession.
Table 22. Rates of increase in health insurance coverage and uninsured, 1990-2009

\begin{tabular}{lccc} 
& \multicolumn{3}{c}{ Percent Change Over Period } \\
\cline { 2 - 4 } & $1990-2000$ & $2000-2009$ & $1990-2009$ \\
\hline Population & $12 \%$ & $9 \%$ & $22 \%$ \\
\hline Total insured & $13 \%$ & $5 \%$ & $18 \%$ \\
\hline Privately insured & $11 \%$ & $-4 \%$ & $7 \%$ \\
\hline Government insured & $13 \%$ & $35 \%$ & $53 \%$ \\
\hline Medicare & $17 \%$ & $15 \%$ & $35 \%$ \\
\hline Medicaid & $22 \%$ & $62 \%$ & $97 \%$ \\
\hline Uninsured & $11 \%$ & $32 \%$ & $46 \%$ \\
\hline
\end{tabular}

Chart 22. Trends in the percentage of the US population insured by private employers, Medicare, and Medicaid, 1990-2009

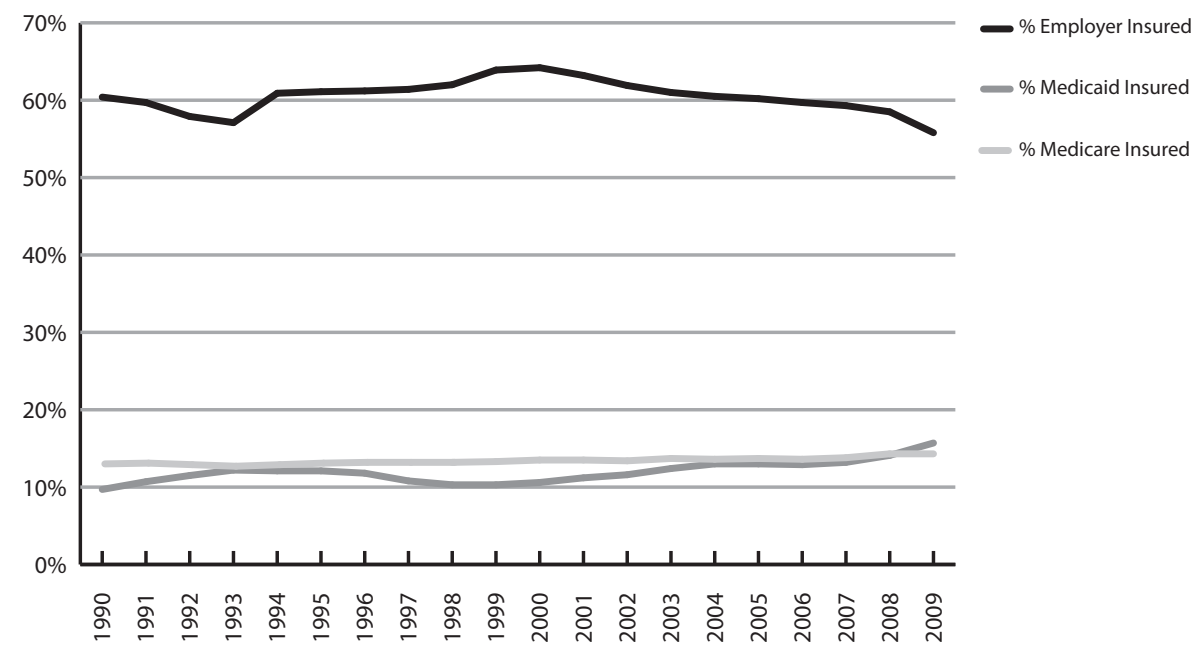

\section{Notes}

Percentage change ignores duplicate coverage. Privately insured includes employer and direct purchase plans.

Source

US Census Bureau (selected years), Current Population Survey.

\section{Note}

Chart excludes small percentage with direct purchase of health insurance. Sources

US Census Bureau (2011); BLS employment statistics. 
Chart

Reasons for Passing Up a Job Opportunity or Postponing Retirement Based on Health Benefits, 2004

\section{The Numbers}

One consequence of the employment-based health insurance system in the United States is the constraint that insurance coverage places on job mobility, referred to as "job lock." Roughly one-quarter of families say they have not retired or they passed up a new job opportunity because they needed to keep their health insurance coverage (Helman, Mathew Greenwald \& Associates, \& Fronstin, 2004).

Chart 23 reports several reasons why workers who passed up a new job opportunity in 2004 did so for medical reasons. Reasons clearly overlap, and all reflect the financial burden of health insurance in one way or another. Thirty-nine percent said they passed on another job because they could not afford to pay for health insurance on their own. Another 15 percent said the new employer did not offer health insurance. Yet another 8 percent said the alternative employer's health plan, while available, cost too much. Thus, about 6 in 10 workers passing on a new job opportunity did so for health insurance cost reasons.

In addition, 14 percent did not accept the new job because of a preexisting medical condition that would not be covered under the new employer's plan. Added to this is 11 percent who said that the prospective employer offered insurance but with fewer benefits. Hence, another one-quarter of job-locked workers were concerned about the financial risk of an uncovered illness or medical condition.

\section{Commentary}

Lack of job mobility has implications for both employment and economic growth. If workers are reticent to quit a job that is a bad fit for them and move to another job where they would be more productive, workforce efficiency suffers. Other workers who wish to retire before they are eligible for Medicare cannot afford to do so. Job lock can raise the unemployment rate among younger workers entering the workforce and frustrate others seeking career advancement.
For more than two decades, policy makers have been concerned about health insurance portability across jobs. The Consolidated Omnibus Budget Reconciliation Act of 1985 (COBRA) allowed individuals who leave or change jobs to keep their current health plans for a limited period of time; however, they are responsible for both the employer and employee portions of the premium. Rapidly rising premiums prevent many individuals from keeping their current health plan, even under COBRA. The Health Insurance Portability and Accountability Act (HIPAA) in 1996 dealt, to some extent, with the issue of preexisting conditions by requiring that workers covered in a previous qualified health plan be covered when they switch workplaces and health plans. Neither COBRA nor HIPAA effectively deals with escalating health insurance premiums or the lack of health insurance coverage at a new job.

Reported job lock could be fairly sensitive to the Affordable Care Act, resulting in greater productivity, a more satisfied workforce, and a reduced financial burden on individuals who had been spending more on insurance after switching jobs. The ACA prohibits denial of coverage because of preexisting conditions, and beginning in 2014, employers with more than 50 employees must offer health insurance or pay a penalty. Individuals will also have the option of purchasing subsidized health insurance in state or federal health exchanges. This may materially reduce the cost of health insurance for workers and encourage increased job flexibility. If a worker (or family) is enrolled in an exchange-based plan, the worker can keep the same plan when he or she changes jobs, although the subsidy may fall if the wage increase is large enough. 
Chart 23. Reasons for passing up a job opportunity or postponing retirement based on health benefits, 2004

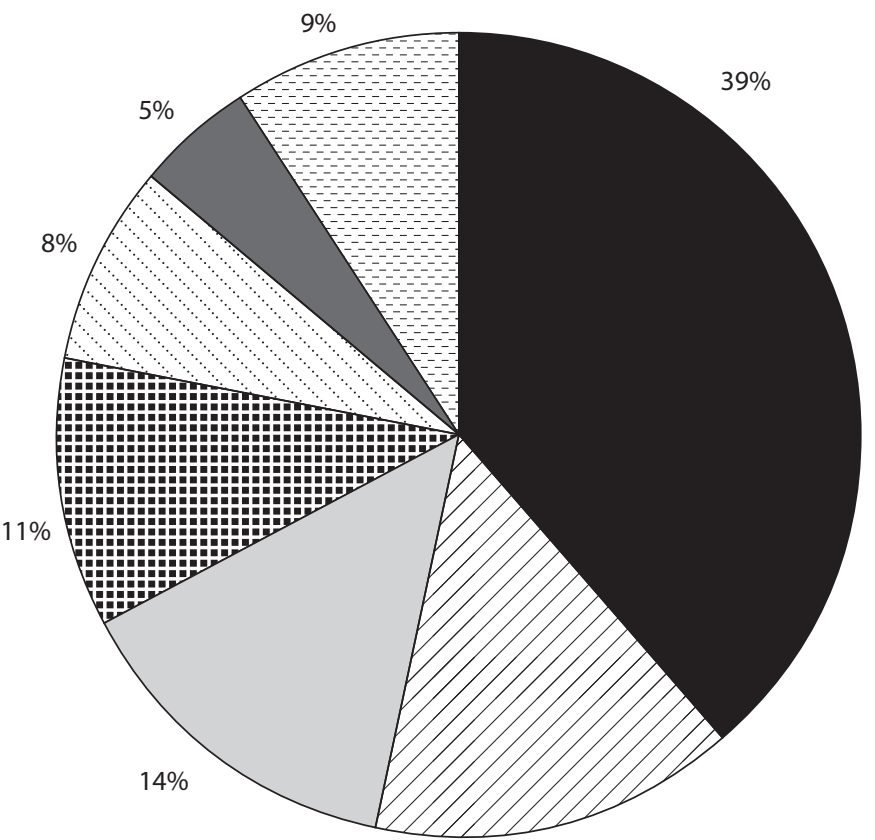

$15 \%$

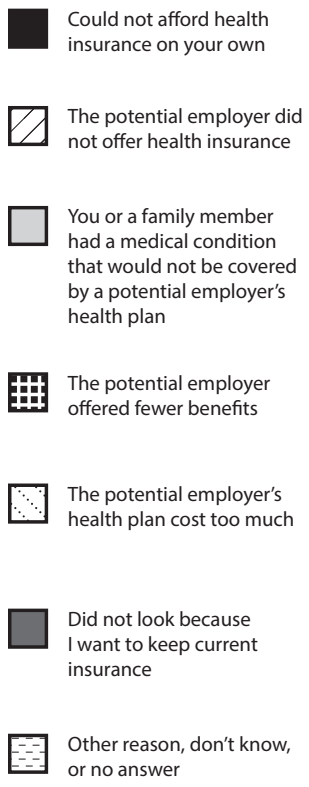

or no answer

\section{Source}

Helman et al. (2004). 


\section{Potential Uses of Excess Household Health Care Spending, 2008: \$80 Billion (\$698 per Household)}

\section{The Numbers}

Over the last two decades, growth in household health care spending exceeded the rate of growth in GDP. If the growth in household health care spending had been limited to the GDP growth rate, households would have saved $\$ 80$ billion in 2008 alone to spend on other goods and services. This amounts to $\$ 698$ per household (Steuerle, July 19, 2011). And this does not include potential tax savings that might have resulted from reduced government spending, potential wage increases that might have resulted from reduced business spending on health care, or potential increases in stockholder income-also from reduced business spending on health care. More importantly, families would have extra money every year in the future, assuming that health care costs continued to grow at the same rate as the GDP.

What would an extra $\$ 698$, ignoring taxes, buy for a typical family? Chart 24 shows some options. With an additional $\$ 698$ per year, at 2011 mortgage rates, a family could afford an additional $\$ 57$ per month on their premiums, which would cover an $\$ 11,900$ larger 30-year mortgage. With the median owneroccupied home valued at $\$ 184,000$ (Perry, 2013), this represents a 6.4 percent increase in the value of the home. Alternately, those behind on their mortgage payments could offset their current mortgage costs by $\$ 57$ monthly.

Alternatively, Chart 24 shows some potential long-term investments the family might choose. If health care costs were aligned with economic growth, households in 2008 would have $\$ 698$ each year over the next several decades to invest. A family with an infant could invest the money in a state-guaranteed tuition program. Setting aside $\$ 57$ per month over 18 years toward a child's education would guarantee one full year at the University of Texas (Texas Promise Fund, http://www.texastuitionpromisefund.com). As many families struggle with paying for a college education, even this small monthly savings in direct out-of-pocket costs can go a long way toward paying for a child's college education.

Many Americans are also concerned about retirement. To maintain the same income during retirement, it is estimated that a family with the national average household income of $\$ 60,000$ a year will need $\$ 876,000$ in private savings (such as a $401(\mathrm{k}$ ) or 403(b) plan), Social Security benefits, and company pensions for retirement (Steuerle, 2011). The average Social Security benefit is $\$ 448,000$, more than $\$ 400,000$ less than the necessary retirement nest egg. Yet today, one-quarter of Americans rely on Social Security for 90 percent or more of their retirement income (Center on Budget and Policy Priorities, 2010), and for those with private retirement plans, the average amount at retirement is only $\$ 61,000$ (Hundley, n.d.). Assuming a 5 percent rate of return, a family that invested $\$ 698$ each year (pre-tax) beginning in 2008 in a qualified retirement plan would have $\$ 9,223$ in 10 years for retirement, $\$ 24,247$ in 20 years, and $\$ 48,720$ in 30 years (Chart 24). This would go a significant way to improving the American family's financial situation at retirement.

\section{Commentary}

Chart 24 illustrates a few of the opportunities that families may be giving up in terms of lifestyle for themselves and their children in exchange for health care spending that has grown 2.2 times faster than GDP, on average, each year since 1970. And for individuals and families, their out-of-pocket spending and insurance premiums are only the tip of the iceberg in terms of the costs they bear, annually, for unconstrained spending on health services. Even greater costs that households bear, as taxpayers, are reflected in the growth in public health care spending. 
Chart 24. Potential uses of excess household health care spending, 2008: $\$ 80$ billion (\$698 per household)
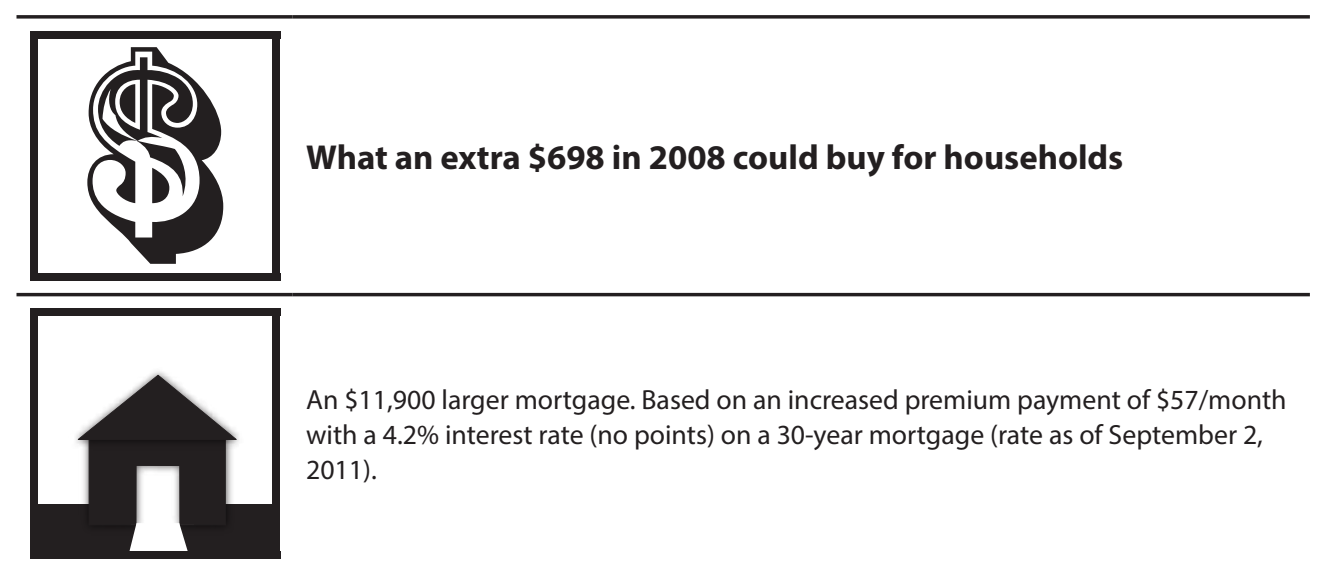

An $\$ 11,900$ larger mortgage. Based on an increased premium payment of $\$ 57 /$ month with a $4.2 \%$ interest rate (no points) on a 30-year mortgage (rate as of September 2, 2011).

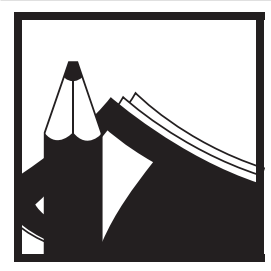

One full year's education at the University of Texas. Account holders purchase Tuition Units, which represent a fixed amount of undergraduate resident tuition and required fees charged by Texas public colleges and universities. The number of units needed varies depending on the school, but generally 100 units represents 30 semester hours, which is considered to be one academic year.

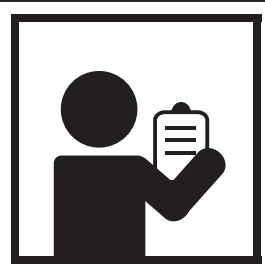

Additional savings for retirement. Based on a $5 \%$ annual rate of return, with

10 years to retirement, investing that extra $\$ 698 /$ year could grow to $\ldots$.

$\$ 9,223$

20 years to retirement, investing that extra $\$ 698 /$ year could grow to ... $\quad \$ 24,247$

30 years to retirement, investing that extra $\$ 698 /$ year could grow to ... $\quad \$ 48,720$
Sources

Texas Tuition Promise Fund (http:// www.texastuitionpromisefund.com); www.bankrate.com. 
Page deliberately left blank. 


\section{PART IV \\ Government: Financial Burden of Health Care \\ Spending}




\section{P4 Key Findings: Government Financial Burden of Health Care Spending}

- Federal health spending rose rapidly with the passage of the two health care entitlement programs, Medicare and Medicaid, reaching \$549 billion by 2005, a 305-fold increase over 1965 . Health spending in 2005 had become the single largest component of the federal budget-larger even than national defense. Federal education spending increased 63-fold; income security, 38 -fold; and Social Security and interest on the national debt each rose 30 -fold. National defense increased only 10 -fold, while spending on general science (excluding health) increased only 4 -fold.

- In 1965, the federal government was spending $\$ 1.60$ on health for every dollar spent on education. Forty years later, it was spending $\$ 8$ on health for every dollar on education. In 1965, the government was spending 31 cents on health for every dollar on general science. By 2005, budget priorities had reversed, with $\$ 23$ of health spending for every dollar on general science. Similarly, the federal government was spending $\$ 3.70$ on income security in 1965 per health dollar compared with only 46 cents per health dollar in 2005.

- In 1980, states were spending 15 percent of their budgets on all health care services compared with 22 percent by 2005 . By 2003, health care became the states' top spending priority ahead of K-12 education. Inflation-adjusted cash welfare declined from $\$ 519$ per poor person to $\$ 403$ between 1980 and 2008, while health care spending per poor person rose from $\$ 2,212$ to $\$ 5,698$.
- The ability of the Congress to reduce the annual budget deficit is seriously diminished by the foregone tax revenues of untaxed employer premiums and Medicare payments for health services. Between 1990 and 2010, untaxed employer-paid health premiums for workers rose 4.2-fold while untaxed health benefits for Medicare beneficiaries grew 5.6-fold. The two major health tax expenditures now exceed by a substantial amount the combined losses in federal revenues from mortgage deductions, Social Security exclusions, and state/local tax deductions.

- It is widely believed that Medicare beneficiaries "pay their own way" by paying payroll taxes and annual premiums into the Medicare trust funds before and after they retire. Yet a single woman retiring in 2010 would have contributed $\$ 58,000$ in Medicare taxes over 43 working years, but her expected benefits from using health services, net of Part B premiums, after 2010 are estimated to be $\$ 185,000$, resulting in a Medicare subsidy of $\$ 127,000$. A one-earner couple can anticipate a subsidy of $\$ 293,000$ compared with a 2-earner subsidy of $\$ 202,000$ from paying more payroll taxes.

- Cost-saving features in the 2010 ACA extended the bankruptcy date of the Part A, Hospital Insurance, fund from 2017 to 2029. Still, as of 2009, the Medicare program was drawing down on accumulated payroll assets, and 75 percent ( $\$ 205$ billion in 2009) of its money to support Medicare Part B, Supplementary Medical Insurance, comes annually from taxpayers. 
- Under Medicaid's federal-state cost-sharing arrangement, the federal government is responsible for between 50 percent and 83 percent of program outlays in the 50 states. However, taxpayers in only 10 of 21 states with aboveaverage wealth in 2005 also bore an above-average burden for their Medicaid program. Conversely, another seven states had below-average wealth yet incurred an above-average taxpayer burden. Twenty-two of 50 states experienced both belowaverage wealth and below-average taxpayer burdens for their Medicaid programs. Many of the poorer Southern states had 70 percent or more of their Medicaid costs funded by the federal government.

\section{- Between 1990 and 2008, GDP increased} nearly 2.5 -fold, but at the same time, federal health spending grew 5.5-fold. Had the federal government constrained its health spending to economy-wide growth, Congress would have had $\$ 274$ billion extra to spend in 2008 alone (9.2 percent more of all federal spending).

- With $\$ 274$ billion in savings in 2008 , the federal government could have

- increased its spending on basic science, elementary/secondary education, and higher education, altogether, by 4.8 -fold, or

- increased spending on ground transportation and natural resources and the environment by 4.3-fold, or

- strengthened the safety net for the lower and middle classes by doubling spending on cash for the disabled and the earned income tax credit, housing subsidies, and food and nutrition programs, or
- eliminated all federal income taxes for federal taxpayers who earned less than $\$ 100,000$ annually ( 88 percent of all households), or

- simply kept the savings and reduced the annual deficit that year by two-thirds to $\$ 177.4$ billion.

- States' health care spending increased 4.6-fold between 1990 and 2008. In 2008 alone, state and local health spending was $\$ 141$ billion above what the growth of GDP since 1990 would have justified. This $\$ 141$ billion in excess health spending would have allowed state and local legislatures to

- more than double their $\$ 135$ billion spent to repair and expand their highways, or

- more than double spending on elementary/ secondary education, or

- reduce all public college and university tuition and room and board costs by 90 percent, or

- cover all of the interest on state debt in 2008 and at the same time reduce state corporate income taxes by 80 percent.

- Excess health care spending across all four funding sources-businesses, households, and federal and state governmentsaccumulated and invested in the stock market over the 1990-2008 period would have amounted to $\$ 6.75$ trillion. Expressing each year's excess spending in constant 2008 dollars still produces a cumulative total of $\$ 4.8$ trillion in forgone investments in America. 


\section{Federal Spending on Health and Other Services, 1965 and 2005}

\section{The Numbers}

In 1965, the year Medicare and Medicaid were enacted, national defense spending dominated all other major federal spending categories (Chart 25), exceeding $\$ 50$ billion (in $\$ 1965$ dollars). Social Security, the second largest demand on federal funds at the time, was only one-third the size of defense spending. Total federal health spending ( $\$ 1.8$ billion) was one-tenth the size of Social Security spending and one-thirtieth of the spending on national defense. Federal spending on health was considerably less than the interest on the public debt (roughly $\$ 12$ billion), income security programs ( $\$ 6.6$ billion), and spending on general science and space ( $\$ 5.8$ billion) or transportation ( $\$ 5.8$ billion). Only federal support for elementary, secondary, and higher education was less ( $\$ 1.1$ billion) than health spending.

Over the next 40 years, federal spending across the eight categories grew dramatically in unadjusted terms, rising from roughly $\$ 100$ billion in 1965 to $\$ 2.3$ trillion by 2005 . The 6 -fold increase in general inflation explains only one-quarter of the 23 -fold spending increase. While spending rose in all eight categories, remarkable shifts in federal spending priorities are evident in Chart 25.

Federal health spending rose rapidly with the advent of the two health entitlement programs, Medicare and Medicaid, reaching $\$ 549$ billion by 2005 , a 305 -fold increase over 1965 . Health spending is now the single largest component of the federal budget-larger even than national defense. Over the same 40 years, federal education spending increased 63-fold, income security increased 38-fold, and Social Security and interest on the national debt each rose 30 -fold. National defense increased only 10-fold, but it started from the largest base. Spending on general science (excluding health) increased only 4 -fold.

The share of health spending among the eight major categories rose from 2 percent to 24 percent over 40 years. Shares devoted to Social Security and public debt also rose several percentage points. Education's share tripled (although it was still only 3 percent by 2005). In 1965, the federal government was spending $\$ 1.60$ on health for every dollar on education. Forty years later, it was spending $\$ 8$ on health for every dollar on education. By 2005, the federal government was spending only 1 percent of its budget in the eight major categories on general science, in addition to minor support for higher education. Transportation and science were the big losers. In 1965, the government was spending 31 cents on health for every dollar on general science. By 2005, budget priorities had reversed, with $\$ 23$ of health spending for every dollar on general science. Similarly, the federal government was spending $\$ 3.70$ on income security in 1965 per health dollar compared with only 46 cents per health dollar in 2005.

\section{Commentary}

Based on Chart 25 there is little doubt that spiraling growth in federal health spending has crowded out increased spending on key public investments in education, general science, and transportation. Federal spending on these three key investments together in 2005 was less than one-third what the government spent on health-mostly in the Medicare and Medicaid entitlement programs. Unless something is done to curb spending growth on Medicare and Medicaid, and quickly, painful sacrifices will have to be made in defense, Social Security, and general income security programs (including cash assistance, food stamps, subsided housing). Little more is available from science and transportation, and the government cannot default on its debt payments. 


\section{Chart 25. Federal spending on health and other services, 1965 and 2005}
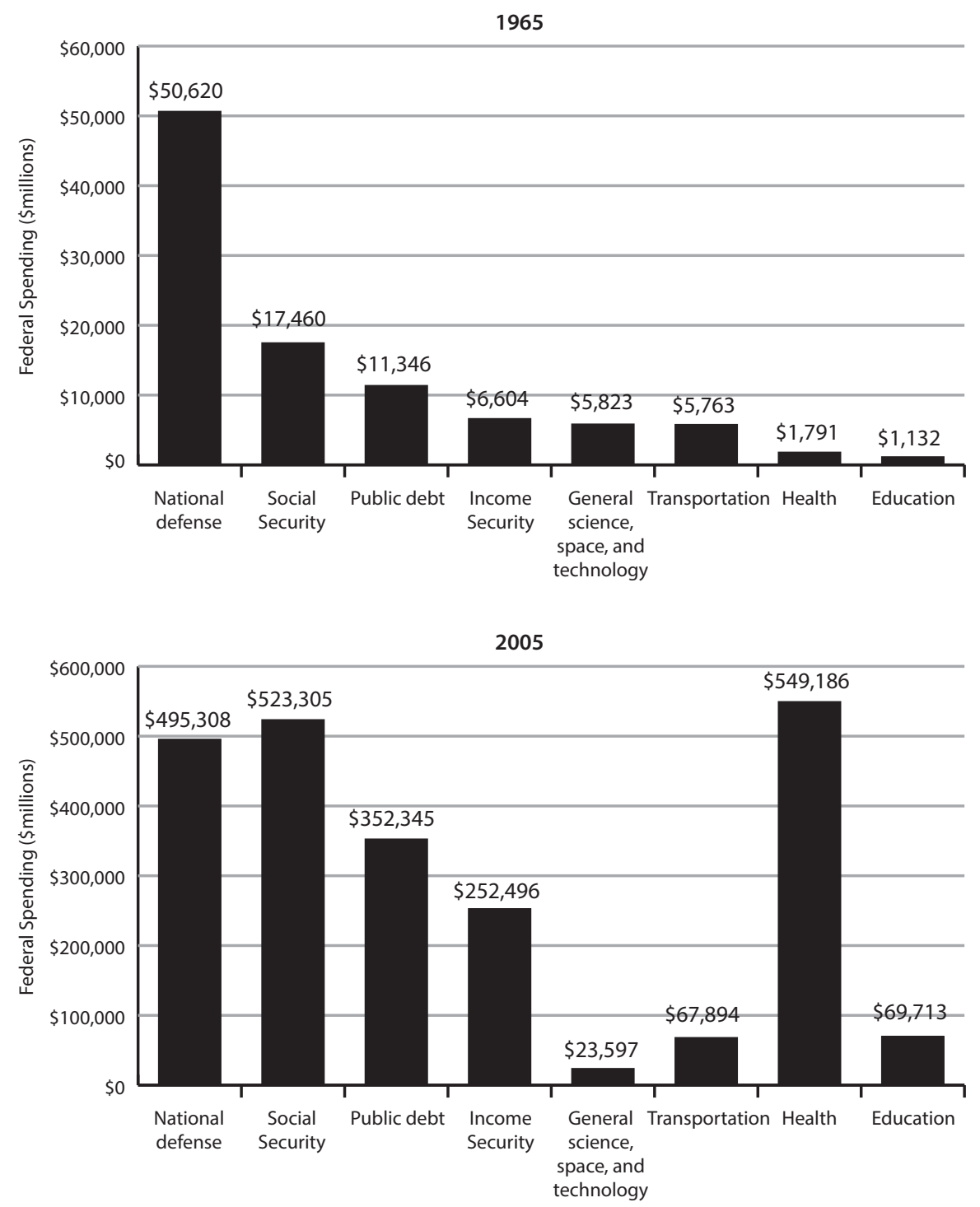

\section{Note}

Spending in 2005 unadjusted for inflation. Health and education spending adjusted for intergovernmental transfers.

\section{Source}

Historical tables: Budget of the US government (multiple years). 
Chart 26 Trends in Shares of State and Local Spending on Health and Other Services, 1980-2008

\section{The Numbers}

The nearly constant state and local share of overall health care spending in the US (Chart 3) understates the real opportunity costs borne by state and local governments. In 1980, states were spending 15 percent of their budgets on all health care services-primarily in their Medicaid programs (Chart 26). Their own health care spending accelerated between 1986 and 1994 when millions of eligible individuals not receiving cash assistance were added to the program. After leveling off for nearly a decade, spending accelerated once again to about 22 percent of state budgets by 2005. States were spending 160 percent more on health care per person in poverty in 2008 than in 1980, a time when health care inflation was already becoming a national concern (see Chart 1).

Except for public safety (mainly police and prisons), practically all other major state functions saw declines in their budget shares over the last few decades. K-12 education has always been the state and local governments' dominant budget priority, but not anymore. That changed in the early 1990s after a sharp acceleration in health care spending. By the early 2000s, health care spending became the states' top spending priority-most likely permanently.

Transportation, the third largest claim on state budgets in 1980, saw its budget share fall from 9.4 percent to 7.2 percent by 2008 . Higher education, always funded at about one-third the rate of elementary-secondary education, saw its share fall slightly. Whereas in 1980, states were spending \$1.91 on health care for every dollar on higher education, 28 years later they were spending $\$ 2.91$ more on health per higher education dollar despite a 40 percent growth in school enrollments (US Census Bureau, 2012).

Cash assistance and in-kind subsidies (e.g., public housing) for the poor experienced the largest relative decline in states' share of spending. Never a significant part of state budgets (only 3.5 percent in 1980), cash welfare fell to just 1.5 percent of spending by 2008 . Inflation-adjusted cash welfare declined from \$519 per poor person to $\$ 403$ over 28 years. At the same time, health care spending per poor person rose by over $\$ 3,000$, from $\$ 2,212$ to $\$ 5,698$ (US Census Bureau, 2012).

\section{Commentary}

States increasingly provide in-kind health care benefits to the poor and unemployed in lieu of cash, food assistance, and other subsidies. But because most of the poor and unemployed do not access the health care system in a costly way during any year, the cash equivalent would be worth far more to them to spend on other goods and services. It is true that states are spending more on higher education, but the increase falls far short of the amounts being spent on health care for the poor. As state health care spending today is 2.6 times that spent on higher education, moderating health outlays can free up funds to educate the next generation of leaders and entrepreneurs. The bill for states' depreciated infrastructure, including transportation, is also coming due after years of neglect.

Sizable state health budgets today make cost containment imperative. Had state and local health care spending continued to increase in 2009 over 2008 at its previous 10 percent rate, to avoid raising taxes to balance budgets, states would have had to

- reduce elementary and secondary education spending by 10 percent, or

- reduce higher education or transportation spending by 25 percent, or

- reduce both cash welfare and public housing spending by 40 percent.

Of course, state legislatures do not offset all of their rising health spending burden by defunding a single service. Rather, given inadequate tax bases, state health care spending is now so large that any increase going forward will necessitate spending reductions on several key public services. This fiscal reality is in spite of the fact that the federal government pays well more than 50 percent of most state Medicaid programs (details on Chart 29). 
Chart 26. Trends in shares of state and local spending on health and other services, 1980-2008

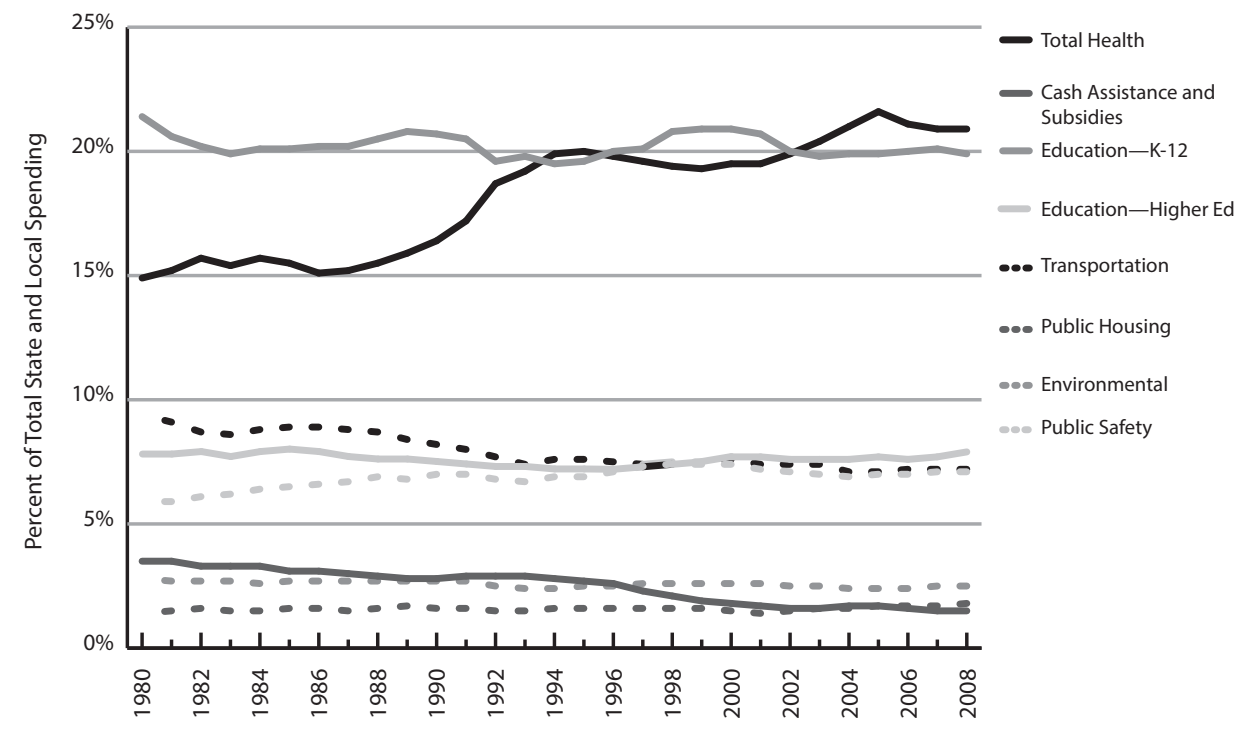




\section{Health Care and Other Major Federal Tax Expenditures, 1990 and 2010}

\section{The Numbers}

The current federal tax code is full of tax loopholes. Ever since 1975, Congress' Joint Committee on Taxation has tracked tax expenditures, or the revenues foregone from tax incentives and tax waivers. While lost revenues are not a new problem, the uncontrolled growth in health care spending has added materially to the revenues that the federal government could recover by limiting tax exemptions and deductions.

Two health care tax expenditures play prominently in the list of major tax expenditures. First, workers do not have to pay income taxes on the health insurance premiums paid by employers on their behalf. Second, Medicare beneficiaries do not have to pay taxes on the difference between what the federal government pays on their behalf for health services and what they pay into the program in the form of accumulated tax contributions and annual premiums. Although home mortgage tax deductions are better known to most Americans, already by 1990 untaxed employer-paid health premiums for workers were $\$ 7.2$ billion greater, $\$ 32.6$ billion versus $\$ 25.4$ billion (Chart 27). Tax exclusions for net Medicare benefits (see also Chart 28) added another $\$ 9$ billion to employer-paid premium deductions, resulting in $\$ 42$ billion in health-related tax expenditures in 1990. Together, the two health care tax expenditures far exceeded mortgage deductions, untaxed Social Security payments, or state and local taxes exempted from federal income taxation. Only untaxed retirement accounts ( $\$ 60$ billion) exceeded health care deductions in 1990.

All major tax expenditures rose over the next 20 years but at very different rates. Exclusions and deductions for Social Security and state/local taxes rose modestly. Mortgage tax expenditures grew 3.6-fold, from $\$ 25$ billion to $\$ 90$ billion because of the inflation in housing prices. Retirement account tax expenditures grew 2.7-fold. As dramatic as these increases were, health care premium deductions grew much faster.
Untaxed health premiums for workers rose 4.2fold, from $\$ 32.6$ billion to $\$ 135.6$ billion. The largest increase in untaxed benefits, however, was reserved for Medicare beneficiaries. Their tax subsidy grew 5.6-fold, from $\$ 9$ billion to $\$ 50$ billion. The two major health tax expenditures now exceed by a substantial amount the combined losses in federal revenues from mortgage deductions, Social Security exclusions, and state/local tax deductions.

\section{Commentary}

The ability of the Congress to reduce the annual budget deficit is seriously diminished by the foregone tax revenues of untaxed employer premiums and Medicare payments for health services. By 2010, employer and Medicare health tax expenditures, combined, approached $\$ 200$ billion, approximately the size of the annual interest paid on the federal debt. Burgeoning Medicare outlays have dual effects on federal deficits. First, Medicare's Part B outlays each year come directly out of general tax revenues and add to the deficit. Second, these same outlays add to foregone revenues when the "Medicare subsidy" goes untaxed.

Because health care spending is relatively immune to economic market swings (Chart 1), the government's lost health care tax revenues continually rise and make them a logical target for reform. Having taken over a greater and greater responsibility for the nation's health care bills, the federal government is looking for ways to cover at least some of its costs. Taxing employer-paid health premiums is a reasonable place to start.

Another argument for taxing employer health premiums and/or raising Medicare Part B premiums is the inefficiency inherent in giving citizens an "underpriced" service like health care. Workers lobby for comprehensive, first-dollar insurance coverage that encourages the use of expensive health services sometimes of marginal value (Phelps, 2003). Shifting some of the cost to workers and the elderly should 
result in more efficient levels of insurance coverage and utilization. Rising out-of-pocket costs are already causing medical bankruptcies (Chart 20). Taxing part of employer-paid premiums would fall mostly on wealthier individuals. The ACA has recognized the seriousness of untaxed health benefits by putting caps on the premiums of so-called Cadillac health plans that would be tax-exempt.

\section{Chart 27. Health care and other major federal tax expenditures, 1990 and 2010}

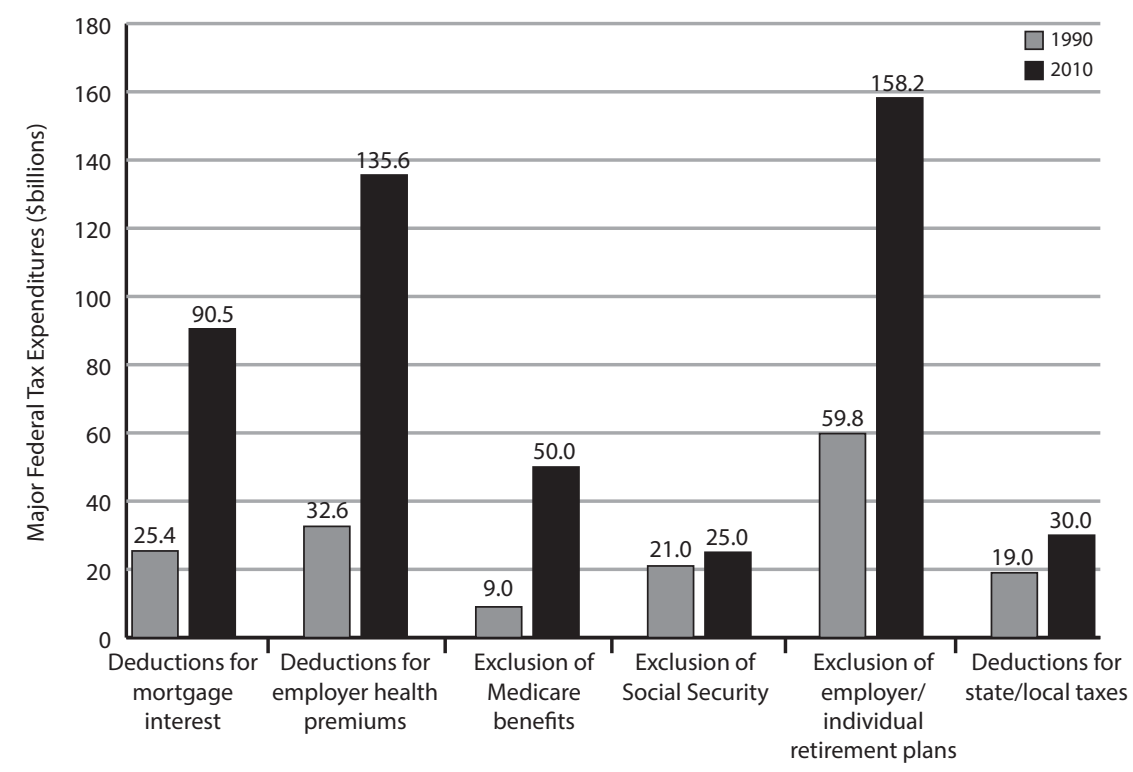
Note
Expenditures unadjusted for inflation
Source
Joint Committee on Taxation (selected years). 


\section{The Medicare Subsidy for Retirees, 1960, 2010, and 2030}

\section{The Numbers}

It is widely believed that Medicare beneficiaries "pay their own way" by contributing payroll taxes into the Hospital Insurance (HI) Part A trust fund during their working career and with annual premiums into the Supplementary Medical Insurance (SMI) Part B trust fund after they retire. Chart 28 and accompanying Table 28-1, based on analysis by Steuerle and Rennane (2011) at the Urban Institute, examines this belief by accumulating taxes paid into the Part A hospital trust fund and comparing them with the net Medicare benefits patients receive for health services after they retire.

Net benefits are the difference between what the program pays providers for beneficiary services over their expected years of eligibility minus Part B premiums that beneficiaries pay into the program after retirement for physician and professional services. The difference between benefits and taxes is the subsidy enjoyed by Medicare-eligible individuals.

Subsidies for workers retiring in 1960, 2010, and 2030 are forecasted using current Medicare spending trends on health services and beneficiary life expectancy tables net of Part B premiums. Annual employee and employer Medicare taxes (each 1.45 percent of wages) are discounted for inflation plus 2 percent to recognize the fact that taxed income today is worth more than taxed income in the future. The 2 percent also allows for a modest rate of return on "foregone income" had beneficiaries not been taxed. Taxes and benefits in Table 28-1 and Chart 28 are presented in 2011 dollars.

For illustrative purposes, Chart 28 shows the Medicare subsidy for three households retiring in different years: a single woman earning the average wage ( $\$ 43,500$ in 2011 dollars); a one-earner couple with the worker earning the average wage; and a twoearner couple with one worker earning a high wage $(\$ 69,600)$ and the other earning the average wage. A single woman earning the average $\$ 43,500$ annual wage (in 2011 dollars) in 1960, the year she retired, would never have paid any Medicare taxes (Medicare started in 1965) but would have received $\$ 23,000$ in average post-retirement, inflation-adjusted Medicare spending on her behalf. Her net subsidy would have been $\$ 23,000$.

A single woman retiring in 2010 would have contributed $\$ 58,000$ in adjusted Medicare taxes over her expected 43 working years and $\$ 87,000$ if not retiring until 2030. Her benefits from using health services, net of Part B premiums, are estimated to be $\$ 185,000$ looking forward from her 2010 retirement, with a Medicare subsidy of $\$ 127,000$. Her net health benefits are projected to be $\$ 275,000$ if retiring in 2030 , ignoring ACA changes, for a subsidy of $\$ 188,000$. (A single man's subsidy, not shown, is slightly less at $\$ 109,000$ due to a shorter life expectancy.) A single woman retiring in 2010 can expect to receive $\$ 3.19$ in paid medical services for every dollar she invested in Medicare. Her return per dollar invested in Medicare is unchanged if retiring in 2030.

The Medicare subsidy for a one-earner couple is far greater than for a single-worker household because the unemployed spouse is also eligible for Medicare. Again, the couple "invests" only $\$ 58,000$ in taxes and premiums if the worker retires in 2010, but the couple's expected net benefits are $\$ 351,000$. This is practically double the benefits enjoyed by a single woman for the same tax investment. (Premiums will be greater for the couple but have been debited from benefits.) The one-earner couple can anticipate a subsidy of $\$ 293,000$ looking beyond 2010 , and a return of $\$ 6.06$ in net medical services for every tax dollar put into the program. For a couple with one current worker intending to retire in 2030, the subsidy jumps to $\$ 440,000$ at current rates of Medicare spending growth.

The subsidy naturally is not as great for a couple with two earners, one earning a wage 60 percent above average and another earning the average wage. Their net Medicare benefits for health services are 
Table 28-1. The Medicare subsidy, net benefits, and taxes

\begin{tabular}{|c|c|c|c|c|c|c|c|c|c|}
\hline \multirow[b]{2}{*}{$\begin{array}{l}\text { Year } \\
\text { Retired }\end{array}$} & \multicolumn{3}{|c|}{ Single Woman $(\$ 43,500)$} & \multicolumn{3}{|c|}{ 1-Earner Couple $(\$ 43,500)$} & \multicolumn{3}{|c|}{$\begin{array}{c}\text { 2-Earner Couple }(\$ 69,600 \\
\$ 43,500)\end{array}$} \\
\hline & $\begin{array}{c}\text { Net } \\
\text { Benefits }\end{array}$ & Taxes & Subsidy & $\begin{array}{c}\text { Net } \\
\text { Benefits }\end{array}$ & Taxes & Subsidy & $\begin{array}{c}\text { Net } \\
\text { Benefits }\end{array}$ & Taxes & Subsidy \\
\hline 1960 & $\$ 23,000$ & $\$ 0$ & $\$ 23,000$ & $\$ 38,000$ & $\$ 0$ & $\$ 38,000$ & $\$ 38,000$ & $\$ 0$ & $\$ 38,000$ \\
\hline 2010 & $\$ 185,000$ & $\$ 58,000$ & $\$ 127,000$ & $\$ 351,000$ & $\$ 58,000$ & $\$ 293,000$ & $\$ 351,000$ & $\$ 149,000$ & $\$ 202,000$ \\
\hline 2030 & $\$ 275,000$ & $\$ 87,000$ & $\$ 188,000$ & $\$ 527,000$ & $\$ 87,000$ & $\$ 440,000$ & $\$ 527,000$ & $\$ 227,000$ & $\$ 300,000$ \\
\hline
\end{tabular}

\section{Chart 28. The Medicare subsidy for retirees, 1960, 2010, and 2030}

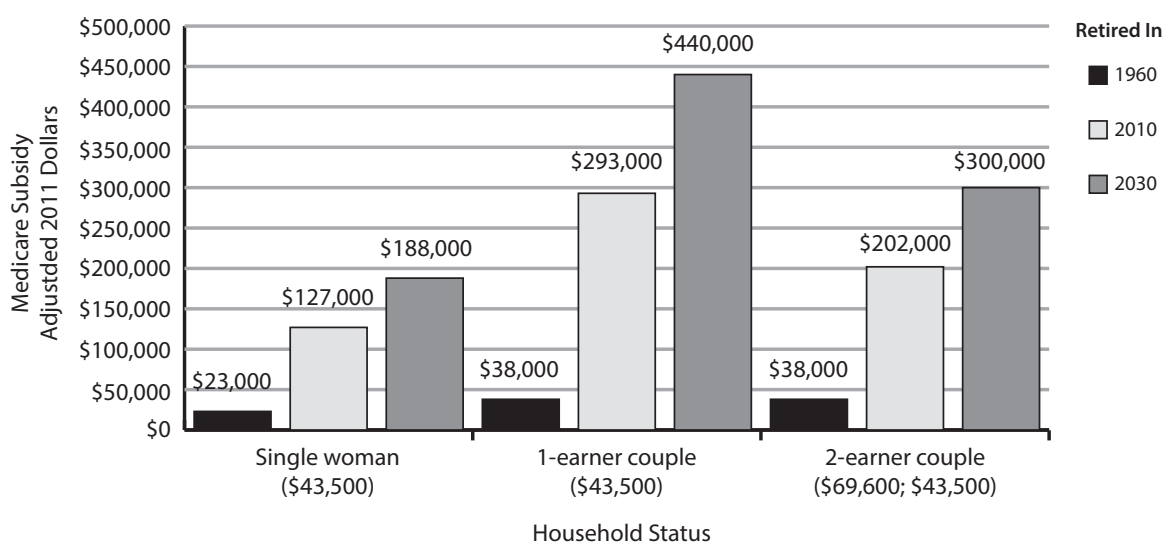

\section{Notes}

Net benefits $=$ Medicare health care payments for beneficiaries minus premiums paid; Taxes = cumulated Medicare employee and employer payroll taxes discounted for inflation $+2 \%$; Subsidy $=$ net benefits minus taxes. All numbers presented in 2011 dollars; $2 \%$ discount rate.

Annual wage in parentheses.

\section{Source}

Steuerle and Rennane (2011).

\section{Notes}

Subsidy in 2011 dollars. Annual wage in parentheses.

\section{Sources}

Medicare benefits: projections in OASDI Board of Trustees Report (2011); Medicare-related payroll taxes: OASDI Trustees Report (2011); Steuerle \& Rennane (2011). 


\section{The Medicare Subsidy for Retirees, 1960, 2010, and 2030 (continued)}

the same as the one-earner couple, but if they retire in 2010, the two earners will have paid, in adjusted terms, $\$ 149,000$ in Medicare taxes instead of $\$ 58,000$. Consequently, their Medicare subsidy $(\$ 202,000)$ is nearly $\$ 100,000$ less than the single-earner couple's subsidy. Nevertheless, this "well-off" couple retiring in 2010 should still enjoy $\$ 2.36$ more in net health services per tax dollar put into the program despite both having paid taxes for 43 years along with paying their post-retirement Medicare premiums.

The elderly and disabled enjoy a similar Social Security subsidy (not shown; Steuerle \& Rennane, 2011). A one-earner couple with average wages retiring in 1980 enjoyed a Social Security subsidy of $\$ 273,000$, double the size of their Medicare subsidy. However, because of rising wages and Social Security tax rates, this subsidy falls to $\$ 153,000$ for persons retiring in 2010. As a result, an average couple retiring in 2010 should enjoy a Medicare subsidy that is double the Social Security cash subsidy.

\section{Commentary}

When the Medicare program was enacted, an immediate financial subsidy was expected because eligible individuals had paid nothing in to support the program. It was considered the cost to society of neglecting the elderly's access to health services for so long. A measure of the program's success is the fact that the elderly's poverty rate has fallen consistently from 9.1 percent in 1980 to 6.1 percent in 2006 (US Census Bureau, 1984, 2009). The Medicare subsidy, along with Social Security, shields the elderly (and disabled), unlike younger Americans, from most of the rapidly rising costs of health care. The Medicare subsidy, however, has grown unabated instead of shrinking as we might expect from workers paying taxes for many years before retiring. This is because national health expenditures, at least since 1980, have grown at roughly double the rate of GDP, a proxy for America's total worker payrolls.
Another little-appreciated consequence of rising health costs is the fact that the Medicare subsidy now dominates any Social Security subsidy. By 2030, roughly two-thirds of the federal government's subsidy of the elderly and disabled will come in the form of in-kind payments for health care rather than in Social Security cash to buy food, housing, and other goods and services (Steuerle \& Rennane, 2011).

Both Medicare Trust Funds, which pay for hospital (Part A, HI) and professional medical services (Part $\mathrm{B}, \mathrm{SMI})$, are in trouble. While cost-saving features in the 2010 ACA extended the bankruptcy date of the Part A hospital fund from 2017 to 2029, the program is now drawing down on accumulated payroll assets ( $\$ 32.3$ billion in 2009; see Table 28-2). According to the Social Security actuaries, net withdrawals will accelerate rapidly after 2022 if spending is not controlled. Yet, as serious as the Part A finances are, over the longer term, the Part B SMI fund is an even bigger problem. Three-quarters of its money comes annually from taxpayers ( $\$ 204.6$ billion in 2009).

With few appreciable assets to draw upon (just $\$ 72.1$ billion at the end of 2009), Part B's drain on general tax revenues will continue to rise far faster than the government's tax base if nothing is done to rein in health care costs.

The Part B SMI funding problem is even worse than indicated in Table 28-2. CMS actuaries by law must forecast outlays assuming that the Congress will authorize far lower payments to physicians in the future because of the Sustainable Growth Rate (SGR) legislation it passed as part of the Balanced Budget Act of 1997. This legislation tied total Medicare spending on physician services to GDP growth. To date, Congress has consistently refused to rescind this legislation that, as of 2012, requires a 27 percent reduction in physicians' Medicare fees. Well aware of building financial pressures, the Congress, in the 2003 Medicare Modernization Act, established the so-called 
Table 28-2. Sources and changes in Medicare Hospital Insurance (HI) and Supplementary Medical Insurance (SMI) trust funds, 2009

\begin{tabular}{lrr}
\hline & Part A, HI (\$billions) & Part B, SMI (\$billions) \\
\hline Assets at end of 2008 & $\$ 304.20$ & $\$ 76.60$ \\
\hline Income during 2009 & & \\
\hline Payroll taxes & $\$ 182.00$ & - \\
\hline General taxes & $\$ 0.10$ & $\$ 204.60$ \\
\hline Interest & $\$ 13.80$ & $\$ 3.10$ \\
\hline Premiums & $\$ 3.30$ & $\$ 58.40$ \\
\hline Other & $\$ 16.50$ & $\$ 4.20$ \\
\hline Total income, 2009 & $\$ 215.60$ & $\$ 270.40$ \\
\hline Expenditures, 2009 & $\$ 247.90$ & $\$ 274.90$ \\
\hline Net change in assets & $-\$ 32.30$ & $-\$ 4.50$ \\
\hline Assets at end of 2009 & $\$ 271.90$ & $\$ 72.10$ \\
\hline
\end{tabular}

\section{Source}

Social Security and Medicare Boards of Trustees (2011).

Doomsday test, requiring the Social Security trustees to notify Congress when Part B general revenues became 45 percent of Medicare outlays. Notification was triggered in 2010, as well as in the previous 4 years, but Congress continues to update physician fees and override (but not rescind) its SGR legislation passed 15 years earlier.

While Medicare's funding picture is bleak, even with savings from the ACA, two facts about the program are worth noting. First, over 98 percent of the Trust Funds' payouts go to pay for the aged and disabled's health care services; 2 percent or less goes to administration (De Lew, 2000). It is a highly efficient program in payouts for health services, if not cost containment. Second, according to the Trustees, a modest increase in the Part A hospital payroll tax from 2.9 percent to 3.6 percent would assure the fund's solvency for the next 75 years (Social Security and Medicare Boards of Trustees, 2011). Still, Part B funding remains a serious problem if left unattended. 


\section{State Wealth and Taxpayer Medicaid Spending Burden, 2005}

\section{The Numbers}

Providing health insurance for all Americans is complicated by the inequalities in wealth across the country. The poor, who are concentrated in some states, cannot afford inflationary health insurance premiums. The fact that governments in poorer states have lower tax bases compounds the problem of paying for public insurance. This is why, in 1965, the Congress enacted the Medicaid program, along with Medicare, to expand public health insurance coverage to both the poor and elderly. Under Medicaid's federal-state cost-sharing arrangement, the federal government is responsible for between 50 percent and 83 percent of program outlays in the 50 states. The federal matching assistance percentage (FMAP) within $50-83$ percent is based on a sliding scale depending on states' per capita income $(\mathrm{Y})$ : FMAP $=1-0.45\left(\mathrm{Y}_{\mathrm{S}} / \mathrm{Y}_{\mathrm{US}}\right)^{2}$. $\mathrm{Y}_{\mathrm{S}} / \mathrm{Y}_{\mathrm{US}}$ is the ratio of a state's per capita income to the US average per capita income. But because Congress placed upper and lower constraints on the sharing formula, and because of varying levels of generosity in service coverage and eligibility authorized by state legislatures, the burden of the program is not borne equally by taxpayers across the country.

In Chart 29, taxpayer burden is defined as the ratio of per capita state-only spending on Medicaid, excluding federal cost sharing, to the state's gross state product, a proxy for state wealth. Taxpayers in only 10 of 21 states (white) with above-average wealth bore an above-average burden for their Medicaid program. Seven of these 10 states were from the Northeast and Mid-Atlantic regions, and only Rhode Island received more than the minimum 50 percent federal sharing of its program costs. By contrast, 11 other states (light gray) with above-average wealth incurred a belowaverage taxpayer burden for their state's portion of Medicaid spending. Eight of these 11 states were west of the Mississippi River.
Another seven states (dark gray) had below-average wealth yet incurred an above-average taxpayer burden for their programs. These states had federal sharing proportions ranging from 54.7 percent (Pennsylvania) to 75 percent (West Virginia). The remaining 22 states (black) experienced both below-average wealth and below-average taxpayer burdens. The majority of these states were in the South and Rocky Mountain areas. Many of the southern states had 70 percent or more of their Medicaid costs funded by the federal government. This substantially reduced the burden on less-well-off taxpayers.

\section{Commentary}

The federal government's cost-sharing arrangement for Medicaid appears to be doing what it was intended to in reducing the health care spending burden of poorer states. With federal sharing rates of two-thirds or more, a large majority of poorer states are bearing a lower financial burden for their Medicaid programs. Southern states and their poor have particularly benefitted from federal cost-sharing. The cost-sharing arrangement has also had a progressive effect in that one-half of wealthier states are bearing a higherthan-average burden for their Medicaid programs (Cromwell et al., 1995). However, a sizable group of states with relatively wealthy taxpayers are bearing a lower-than-expected burden (e.g., Texas, Illinois, Virginia).

Remaining inequities in state Medicaid funding burdens can be attributed to five factors. First, some state legislatures decide to fund more generous (e.g., Vermont and West Virginia) or more restrictive (e.g., Texas and Illinois) Medicaid programs than their wealth would support, on average. Restrictive states constrain their programs and pass on some of the federal cost-sharing to taxpayers in the form of lower taxes. Texas continues to operate a very limited Medicaid program, despite having the highest 
percentage of uninsured in the country (US Census Bureau, 2011). Second, states vary in the number of poor actually eligible for Medicaid under existing rules, e.g., fewer single mothers and children in Wyoming compared with California. Third, states in the Northeast have more expensive hospitals, which raises the cost of care but is not reflected in the costsharing formula. Fortunately for them, they also can draw upon above-average taxpayer wealth. Fourth, the cost-sharing focus on per capita income misses some key alternative sources of tax revenues, such as tourism in Nevada and mineral wealth in Wyoming, Alaska, and Montana, that result in overly generous federal funding of their Medicaid program. And fifth, the 50 percent minimum federal-sharing floor results in inefficient targeting of federal cost-sharing to several wealthier states, money that would be better used in poorer states.

\section{Chart 29. State wealth and taxpayer Medicaid spending burden, 2005}

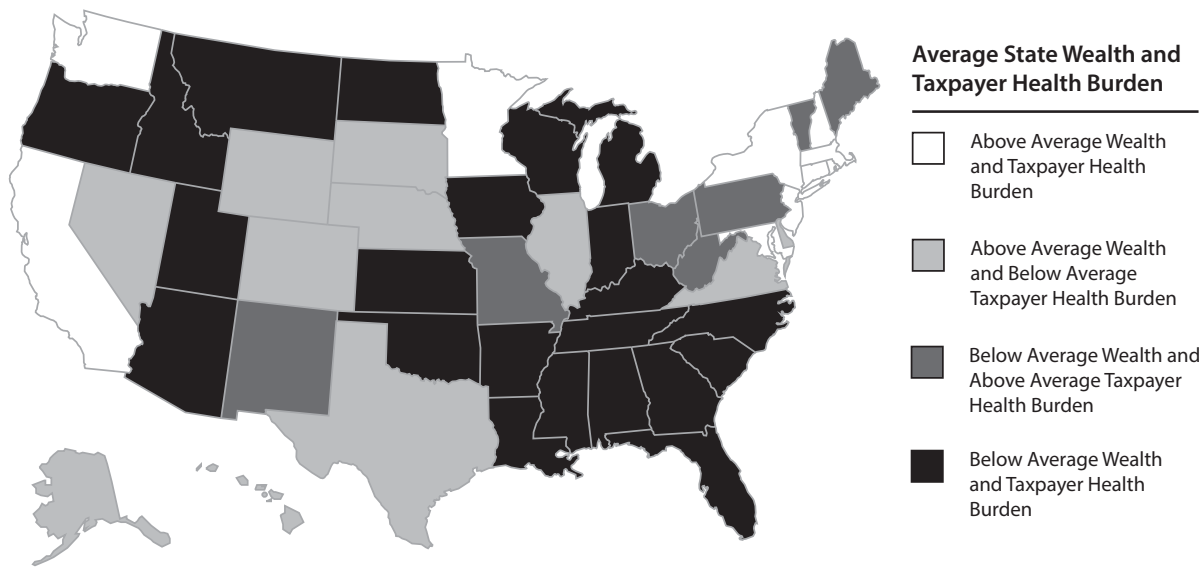

Notes

State wealth $=$ gross state product (GSP); Taxpayer health burden = stateonly Medicaid spending as a percent of state GSP.

\section{Sources}

Centers for Medicare \& Medicaid Services, Office of the Actuary (2007); Centers for Medicare \& Medicaid Services (2006), CMS-64 Quarterly Expense Report; US Census Bureau (2007, 2011); Bureau of Economic Analysis (2009). 


\section{Chart Chart 3021 Potential Uses of Excess Federal and State Health Care Spending, 2008}

\section{The Numbers: Federal Government}

Spiraling health care spending has forced governments at all levels to make trade-offs with other valuable programs. One way to characterize the opportunity costs of this spending is to imagine how much of their budgets would have been available in 2008 for other programs had health care spending been constrained to the rate of growth in America's GDP since 1990, 18 years earlier. The figures shown in Chart 30 present "excess" federal government spending above economywide growth in 2008 alone.

Between 1990 and 2008, GDP increased nearly 2.5-fold, unadjusted for inflation (CMS, 2012). At the same time, federal health spending grew 5.5 -fold and state spending 4.6 -fold. Had the federal government constrained its health spending to economy-wide growth, Congress would have had $\$ 273.7$ billion excess to spend in 2008 alone ( 9.2 percent more of all federal spending) on other needed activities or to return to taxpayers.

The $\$ 273.7$ billion in savings in 2008 could have allowed the federal government to increase its spending on general and basic science, elementary/ secondary education, and higher education from $\$ 73.1$ billion to $\$ 346.8$ billion, a 4.8 -fold increase. Alternatively, if Congress wanted to focus on repairing the US infrastructure, it could have increased spending on ground transportation and natural resources and the environment 4.3-fold to $\$ 355.6$ billion, fixing bridges and highways, funding high-speed commuter rail lines, reducing pollution, and guaranteeing a clean water supply. Or Congress could have strengthened the safety net for the lower and middle classes by doubling spending on public assistance (cash for the disabled, earned income tax credit, etc.), housing subsidies, and food and nutrition programs.
If, instead, the federal government decided to reduce the burden on taxpayers or put its finances in order, with the extra $\$ 273.7$ billion it could have eliminated all federal income taxes for federal taxpayers who earned less than $\$ 100,000$ annually (88 percent of all households). Alternatively, the Congress could have paid 60 percent of the interest it owed on $\$ 451$ billion in Treasury bonds in 2008. Or it simply could have avoided paying out the $\$ 273.7$ billion and reduced the annual deficit that year by two-thirds to $\$ 177.4$ billion.

\section{The Numbers: State Governments}

While the overall share of health spending that states are responsible for has remained nearly constant, they still have spent well above the growth in GDP. In 2008 alone, state and local health spending was $\$ 140.9$ billion above what the growth of GDP since 1990 would have justified. This $\$ 141$ billion in excess health spending would have allowed state and local legislatures to more than double their $\$ 135$ billion spent to repair and expand their highways (Chart 31). Or states could have increased spending on police protection 2.8 -fold to $\$ 220$ billion. Or they could have nearly doubled spending on elementary/secondary education with a commensurate increase in classroom teachers. Instead, states could have put all of the savings into higher education and reduced public college and university tuition and room and board costs by 90 percent. The University of California, Berkeley, the University of North Carolina, the University of Texas, and the University of Michigan, to name just a few universities, could have been practically free. Too much spending in financially troubled times? States could have used the $\$ 141$ billion to cover all of the interest on their debt in 2008 and still reduce state corporate income taxes by 80 percent. 


\section{Chart 30. Potential uses of excess federal health care spending in 2008: $\$ 273.7$ billion}

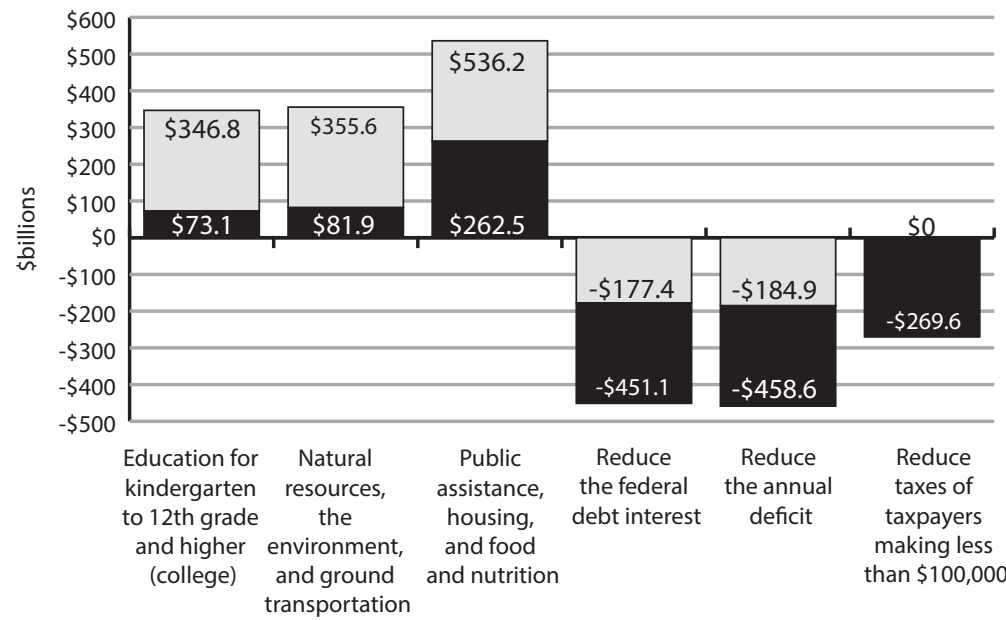
(Debt) in 2008

$\square$ Total with Excess

\$273.7 Billion

Federal Health

Spending in 2008

Note

Dark segments of positive bars indicate federal spending before adding excess health spending; for negative bars, light segments indicate remaining federal spending after allocating excess health spending.

\section{Sources}

Budget of the US government, historical tables; US Census Bureau (2006), Statistical Abstract.

\section{Chart 31. Potential uses of excess state health care spending in 2008: $\$ 140.9$ billion}

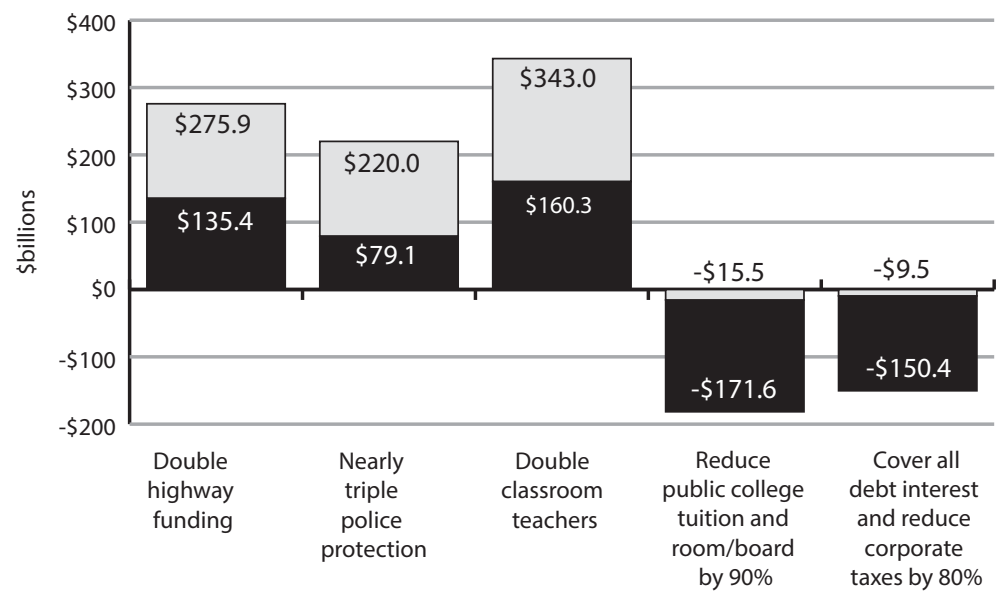

Actual Spending in 2008

$\square$ Total with Excess $\$ 140.9$ Billion Stat Health Spending

\section{Note}

Dark segments of positive bars indicate state spending before adding excess health spending; for negative bars, light segments indicate remaining state spending after allocating excess health spending. Source

US Census Bureau (2008), annual survey of state government finances, retrieved from http://www.census. gov/govs/state. 


\section{Chart Chart 20 Potential Uses of Excess Federal and State Health Care Spending, 2008 (continued)}

\section{Commentary}

Since 1990, the federal government has been burdened with nearly one-half of all excess health spending incurred by employers, households, and federal and state governments. States have contributed another 24 percent. By 2008 , total federal ( $\$ 273.7$ billion) and state and local ( $\$ 141$ billion) excess health spending amounted to $\$ 415$ billion. The opportunity cost of burgeoning federal health care spending represents large foregone investments in science, education, transportation, and the social safety net. Rising health care spending is also a major contributor to the federal government's deficit. Part B subsidies, alone, are now costing the federal government over $\$ 200$ billion a year (see Table 28-2), or roughly three times what it spends on general science and education.

Also, in a time when states are having to limit, or roll back, investments in higher education, to lay off teachers in primary and secondary schools, and when they are having to cut back on the number of firefighters and police and deferring maintenance on their highways and other infrastructure, they are spending billions more each year on public healthprimarily in meeting the obligations of their Medicaid programs.

For a long time, state legislatures could ignore spiraling health care spending because it was a small share of their overall spending. But now that health spending is over 20 percent of their annual budgets, which by law must be balanced, any increases in excess spending going forward seriously limits states' ability to maintain other services while holding the line on taxes. 


\section{Chart} 32 Cumulated Invested Excess Health Care Spending: Businesses, Households, the Federal Government, and State/Local Governments, 1991-2008

\section{The Numbers}

In the year 2008, the total excess health care spending for businesses, households, and governments was $\$ 587$ billion (Charts 14, 24, 30, 31). But the figure for a single year is just the tip of the iceberg. Chart 32 shows the amount of excess spending that has accumulated since 1990 for each of the four spending sources. The total under each line is also provided in Table 32. Each funding source's excess spending is determined, first, by constraining actual health care spending to the growth in GDP since 1990. Next, the annual excess amounts are compounded by the 8.6 percent actual annual growth in the Dow Jones Stock Market Index (http://StockCharts.com). For instance, excess business health spending in 1991 (over 1990) was $\$ 7.9$ billion in 1991 dollars. Had businesses invested the $\$ 7.9$ billion in the stock market through 2008, the investment would have been worth $\$ 34.2$ billion. Cumulating annual savings over the 18 years from 1990 through 2008 , businesses would have had an extra $\$ 1.43$ trillion (Table 32, on page 82) if excess savings had been invested in the stock market ( $\$ 1.02$ trillion if expressed in 2008 dollars).

The cumulative excess spending for households over the 1990-2008 period, if reinvested, would have been $\$ 402$ billion. Household excess spending was actually negative for several years in the early to mid-1990s because annual out-of-pocket spending increased relatively slowly compared with the growth in GDP. Then, beginning in 2001, households have consistently lost money as their own direct spending on health care has outstripped the rate of GDP growth. The recession year 2008 appears to have been particularly difficult, with $\$ 80$ billion in additional excess health care spending because household spending growth of 5.1 percent far exceeded the 1.9 percent growth in GDP.

Cumulated and invested over the 1990-2008 period, excess federal and state health care spending, in 2008 dollars, were $\$ 3.2$ trillion ( $\$ 2.2$ trillion in $\$ 2008$ ) and $\$ 1.7$ trillion ( $\$ 1.23$ trillion in 2008 dollars), respectively. About one-half of all excess federal and state health spending was incurred from 2003 through 2008. Had governments invested annual excess savings in the stock market, total savings would have amounted to $\$ 4.9$ trillion over 18 years.

Excess health care spending in total, accumulated and invested in the stock market over the 1990-2008 period, would have amounted to $\$ 6.75$ trillion. Expressing each year's excess spending in 2008 dollars produces a cumulative total of $\$ 4.8$ trillion.

\section{Commentary}

In almost all years, at least since 1965, health care spending in the US has exceeded the growth in GDP (Chart 1). From an economic perspective, this is not surprising in a wealthy country. Health care is considered a superior good whose share of the budget rises with income-unlike food and clothing. Americans' rising incomes was a major reason why Congress passed Medicare and Medicaid in 1965 to provide better access to care for the elderly and poor citizens. It must be recognized, however, that health care spending cannot take up a growing share of a country's productive capacity forever. At its current size, any increase in health care spending exceeding real GDP growth involves painful shifts of resources away from other needed goods and services. Just looking back to excess spending since 1990, the bill has been substantial: $\$ 4.8$ trillion in 2008 dollars.

How do we know when we as a country are spending too much on health care? Granted, there is no magical percentage of GDP that a country should not exceed. No expert knows what that maximum is. But what we can measure are the repercussions that "excess" health care spending has on business (and workers), households, and federal and state governments. When health care premiums are seriously limiting wage increases and investments in new technologies; when premiums and out-of-pocket costs are a major cause of personal bankruptcies; when 
premiums force 50 million Americans to go without health insurance; when the federal government is seriously limiting investments in education and general science and running large deficits; and when state excess health spending exceeds K-12 education costs and results in flat-funding of higher education-this is when Americans can say that the cost is becoming too great. This is when the many calls for health reform are given more consideration, as evidenced by the passage of the Affordable Care Act in 2010. Only if Americans are fully aware of the many varied, often hidden, opportunity costs of continuing to spend on health services can they (will they) begin to demand change.

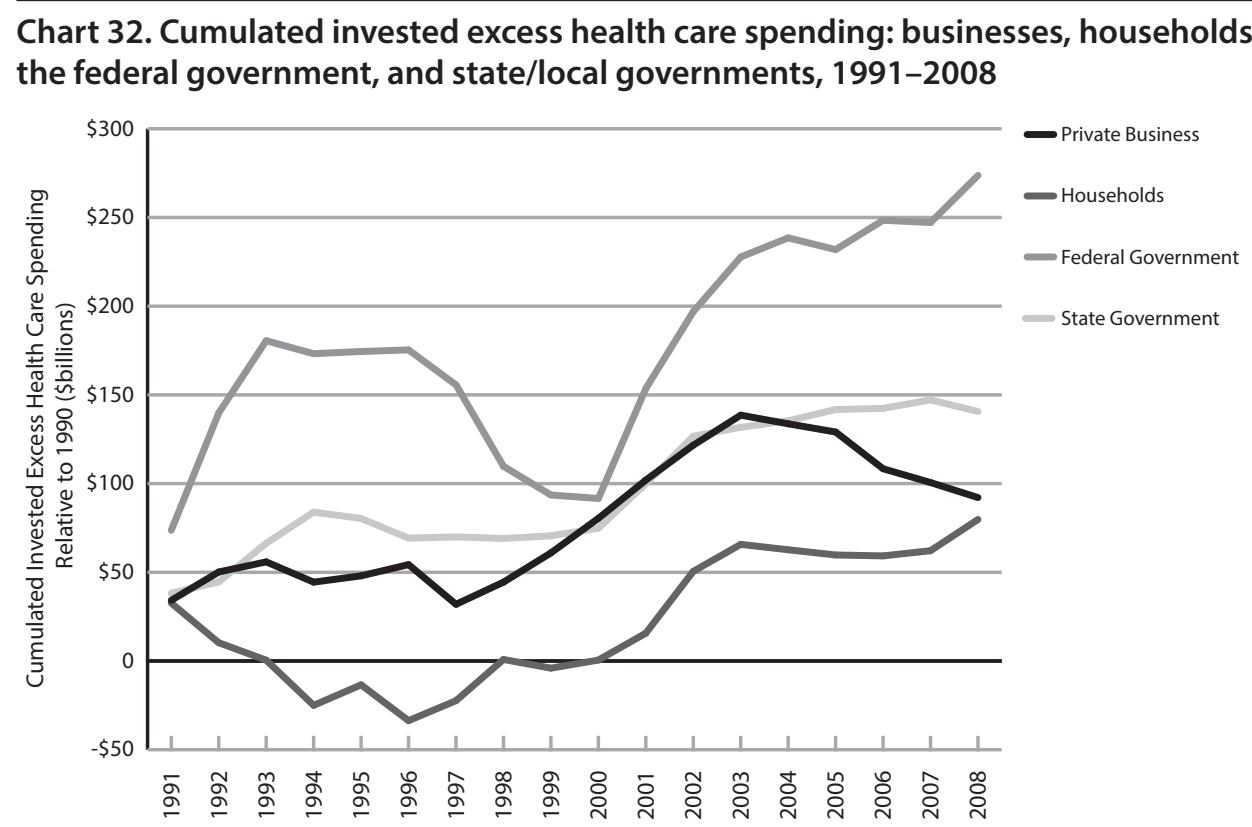

Notes

Cumulative value of excess spending over 1991-2008 based on actual health care spending and constrained to the growth in GDP. The excess is expressed in 2008 dollars and then compounded by the 8.6 percent annual growth in the Dow Jones Stock Market Index.

Sources

Centers for Medicare \& Medicaid Services (2012), national health expenditure data; StockCharts.com (2012). 
Table 32. Aggregate annual excess health care spending invested over 1991-2008 period, in billions of 2008 dollars

\begin{tabular}{lrrrr}
\hline Year & Private Business & Households & Federal Government & State Government \\
\hline 1990 & - & - & - & - \\
\hline 1991 & $\$ 34.2$ & $\$ 32.7$ & $\$ 73.7$ & $\$ 38.2$ \\
\hline 1992 & $\$ 50.2$ & $\$ 10.3$ & $\$ 139.8$ & $\$ 44.6$ \\
\hline 1993 & $\$ 55.9$ & $\$ 0.5$ & $\$ 180.5$ & $\$ 66.3$ \\
\hline 1994 & $\$ 44.5$ & $-\$ 25.0$ & $\$ 173.2$ & $\$ 83.9$ \\
\hline 1995 & $\$ 48.0$ & $-\$ 13.4$ & $\$ 174.5$ & $\$ 80.4$ \\
\hline 1996 & $\$ 54.3$ & $-\$ 33.6$ & $\$ 175.4$ & $\$ 69.3$ \\
\hline 1997 & $\$ 32.0$ & $-\$ 22.4$ & $\$ 155.6$ & $\$ 69.9$ \\
\hline 1998 & $\$ 44.4$ & $\$ 0.9$ & $\$ 109.8$ & $\$ 69.1$ \\
\hline 1999 & $\$ 60.9$ & $-\$ 4.0$ & $\$ 93.6$ & $\$ 70.6$ \\
\hline 2000 & $\$ 80.4$ & $\$ 0.5$ & $\$ 91.6$ & $\$ 74.8$ \\
\hline 2001 & $\$ 102.0$ & $\$ 15.7$ & $\$ 153.6$ & $\$ 99.9$ \\
\hline 2002 & $\$ 121.6$ & $\$ 50.5$ & $\$ 196.9$ & $\$ 126.7$ \\
\hline 2003 & $\$ 138.6$ & $\$ 65.7$ & $\$ 227.7$ & $\$ 131.7$ \\
\hline 2004 & $\$ 133.7$ & $\$ 62.7$ & $\$ 238.5$ & $\$ 135.4$ \\
\hline 2005 & $\$ 129.1$ & $\$ 59.8$ & $\$ 231.9$ & $\$ 141.7$ \\
\hline 2006 & $\$ 108.4$ & $\$ 59.2$ & $\$ 248.4$ & $\$ 142.4$ \\
\hline 2007 & $\$ 100.6$ & $\$ 62.2$ & $\$ 247.1$ & $\$ 147.2$ \\
\hline 2008 & $\$ 92.1$ & $\$ 79.8$ & $\$ 273.7$ & $\$ 140.6$ \\
\hline Cumulative, & $\$ 140.80$ & & $\$ 1,732.8$ \\
\hline $1991-2008$ & & & & \\
\hline & & & & \\
\hline
\end{tabular}

\section{Notes}

Cumulative value of excess spending over 1991-2008 based on actual health care spending and constrained to the growth in GDP. The excess is expressed in 2008 dollars and then compounded by the 8.6 percent annual growth in the Dow Jones Stock Market Index.

\section{Sources}

Centers for Medicare \& Medicaid Services (2012), national health expenditure data; StockCharts.com (2012). 


\section{PART V \\ Health Benefits from Health Care Spending}





\section{D5 Key Findings: Health Benefits from Health Care Spending}

- Over the last quarter century, there has been a gradual increase in life expectancy, a gain of 3.8 years through 2007. Life expectancy for blacks was 5 years less than it was for whites in 1981, but increased 4.7 years compared with a gain of 3.6 years for whites.

- Overall, infant mortality in the United States fell from 12.6 per 1,000 births in 1981 to 6.8 per 1,000 births in 2007 , a 46 percent reduction. In percentage terms, both whites and blacks have experienced similar improvements in infant mortality; blacks have experienced reductions in infant deaths of 8 to 9 per 1,000 compared with 5 per 1,000 for whites. The overall rate of decline in infant mortality slowed markedly beginning in the mid-1990s and has been essentially flat since 2001. However, in some states and in the nation's capital, the infant mortality rate in 2009-2010 was higher than in many countries thought to have inferior health systems, including Botswana and Panama.

- Infant mortality is correlated with insurance coverage. States with below-average insurance coverage are twice as likely to have high infant mortality rates. Texas and the Rocky Mountain states are exceptions, suggesting that other factors are at play such as the availability of health professionals, which is strongly correlated with infant mortality rates.
- Adjusted death rates from heart disease fell by more than one-half, from 397 per 100,000 people in 1981 to only 191 per 100,000 in 2007. Age-adjusted death rates from cancer, by contrast, actually increased from 1981 through the early 1990s before falling slightly in the 2000s. There is no discernible difference in death rates due to heart disease between states with above- or below-average insurance coverage. Deaths due to heart disease, however, are more common in states with higher percentages of adults who are overweight or obese.

- Insurance coverage is correlated with cancer screening. States with below-average insurance coverage are seven times more likely to have low cancer screening rates than states with aboveaverage insurance coverage.

- In 2009, the US health care system ranked last overall and for safe care, cost-related problems, efficiency, equity, and long, healthy lives when compared with six other industrialized countries. The Netherlands ranked first, and the United Kingdom second, in overall health care system performance. Yet US health care spending per capita was nearly double the spending in the Netherlands and two and onehalf times greater than in the UK. 


\section{Trends in US Life Expectancy at Birth, Whites and Blacks, 1981-2007}

\section{The Numbers}

More effective and accessible health care of higher quality should lead to a healthier population (Cutler, Rosen, \& Vijan, 2006). Chart 33 shows life expectancy at birth for the entire US population from 1981 to 2007, and for whites and blacks separately. Life expectancy at birth is determined as the average number of years that a cohort of infants would live if they experienced the age-specific death rates present in their year of birth.

Over the last quarter century, there has been a gradual increase in life expectancy, which continues a trend going back to 1900. Life expectancy at birth in the US increased 5.1 percent between 1981 and 2007 , from 74.1 years to 77.9 years, a gain of 3.8 years. Life expectancy for blacks was 5 years less than it was for whites in 1981, but this gap narrowed somewhat over the next 26 years. The life expectancy of blacks increased from 68.9 years in 1981 to 73.6 in 2007, a gain of 4.7 years ( 6.8 percent). By contrast, the life expectancy of whites rose only 4.8 percent, from 74.8 years in 1981 to 78.4 years in 2007, a gain of 3.6 years.

\section{Commentary}

Over the same 1981-2007 time period, per capita spending on health care increased 3.5-fold in unadjusted terms (CMS, 2013). After factoring out general inflation in the economy, the per capita increase was 1.5-fold. Over the same 26 years, America spent $\$ 16.5$ trillion on health care after adjusting for general inflation (CMS, 2013). While health care plays a role in extending life, most health care spending goes toward a healthier life (e.g., hip and knee replacements, fixing broken arms) rather than on life-extending interventions. Nonetheless, the gains in life expectancy alone have been costly, especially for older people (Cutler et al., 2006). 
Chart 33. Trends in US life expectancy at birth, whites and blacks, 1981-2007

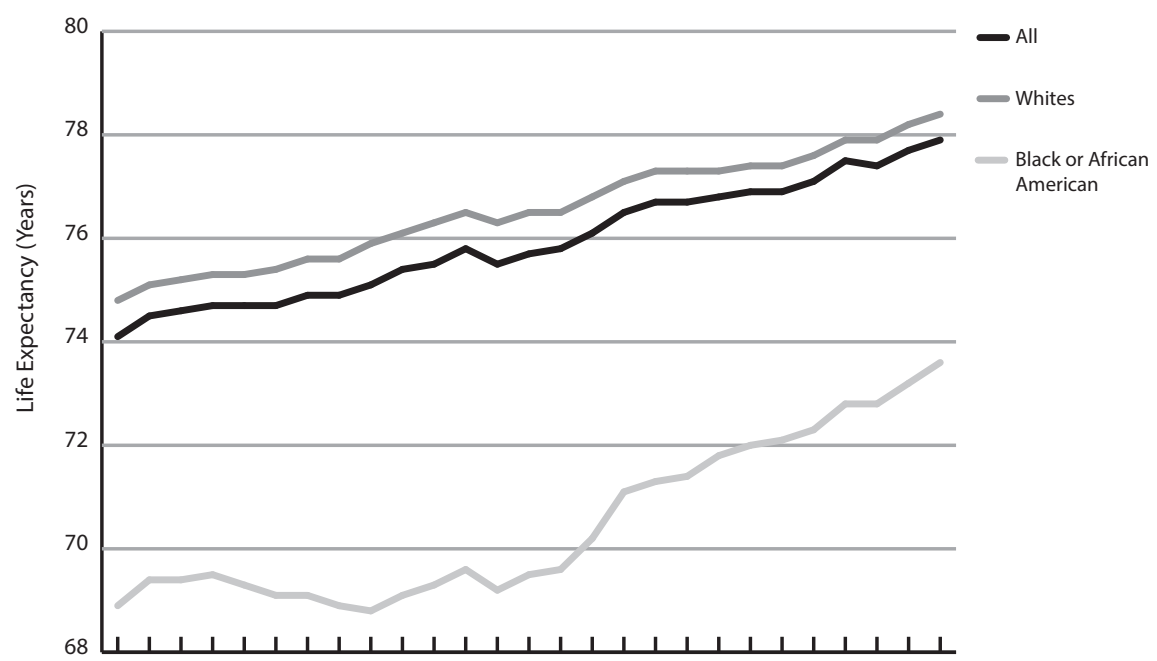

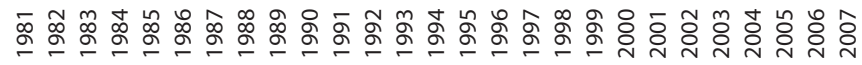

Year of Birth

Source

$\mathrm{Xu}$, Kochanek, Murphy, \& Tejada-Vera (2010). 


\section{Chart} $2 \Lambda$ Trends in Infant Mortality per 1,000 Births, Whites and Blacks, 1980-2007

\section{The Numbers}

Raising life expectancy is possible at both ends of life. Chart 34 shows trends in infant mortality per 1,000 births from 1980 to 2007. Overall, infant mortality in the United States fell from 12.6 per 1,000 births in 1981 to 6.8 per 1,000 births in 2007 , a 46 percent reduction in mortality.

In 1980, infant death rates in America were far higher for blacks than whites (22.2 per 1,000 for blacks; 10.9 for whites). In percentage terms, both races have experienced similar improvements (about a 48 percent reduction in infant mortality for whites and 40 percent for blacks). Starting from a much higher death rate, though, blacks have reduced deaths by 8-9 per 1,000 compared with 5 per 1,000 for whites.

The overall rate of decline slowed markedly beginning in the mid-1990s and has been essentially flat since 2001.

\section{Commentary}

Over the long run, the reductions in infant mortality in the US have been impressive. In 1950, infant mortality was 29.2 per 1,000 births compared with 6.8 per 1,000 in 2007. Infant mortality for blacks was as high as 43.9 per 1,000 in 1950 compared with 13.2 per 1,000 in 2007 (Xu, Lochanek, Murphy, \& Tejada-Vera, 2010).

Some of the decline in infant mortality is due to fewer deaths from sudden infant death syndrome (SIDS) simply by putting babies to sleep on their backs. In addition, substantial investments have been made in neonatal intensive care units in giving low-birthweight babies a normal life. Medical advances such as incubator design and new drugs have produced $\$ 5$ of additional health benefits for each additional $\$ 1$ spent treating low-birth-weight babies (Cutler, 2005).
Although the mortality rate will never be driven to zero, success in other industrialized countries has been greater at lower cost. In fact, in some states and in the nation's capital, the infant mortality rate is higher than in many countries thought to have inferior health systems, including Botswana and Panama (Kaiser State Health Facts, n.d.; CIA, 2012).

The ACA should improve Americans' access to health professionals and prescription drug coverage in several ways. First, by mandating that immunizations and annual physician check-ups be covered without any deductibles or co-payments, parents will not have to forgo these preventive services for their children for financial reasons. Second, the ACA might be able to reduce infant mortality by affording subsidized access to health care for many low-income and uninsured women. Several million women will gain insurance as Medicaid coverage expands to 133 percent of the poverty level in states with currently more restrictive eligibility thresholds. This is particularly valuable for women with complicated pregnancies due to diabetes or high blood pressure. More of these women will have financial access to health care earlier, resulting in lower infant mortality. 
Chart 34. Trends in infant mortality per 1,000 births, whites and blacks, 1980-2007

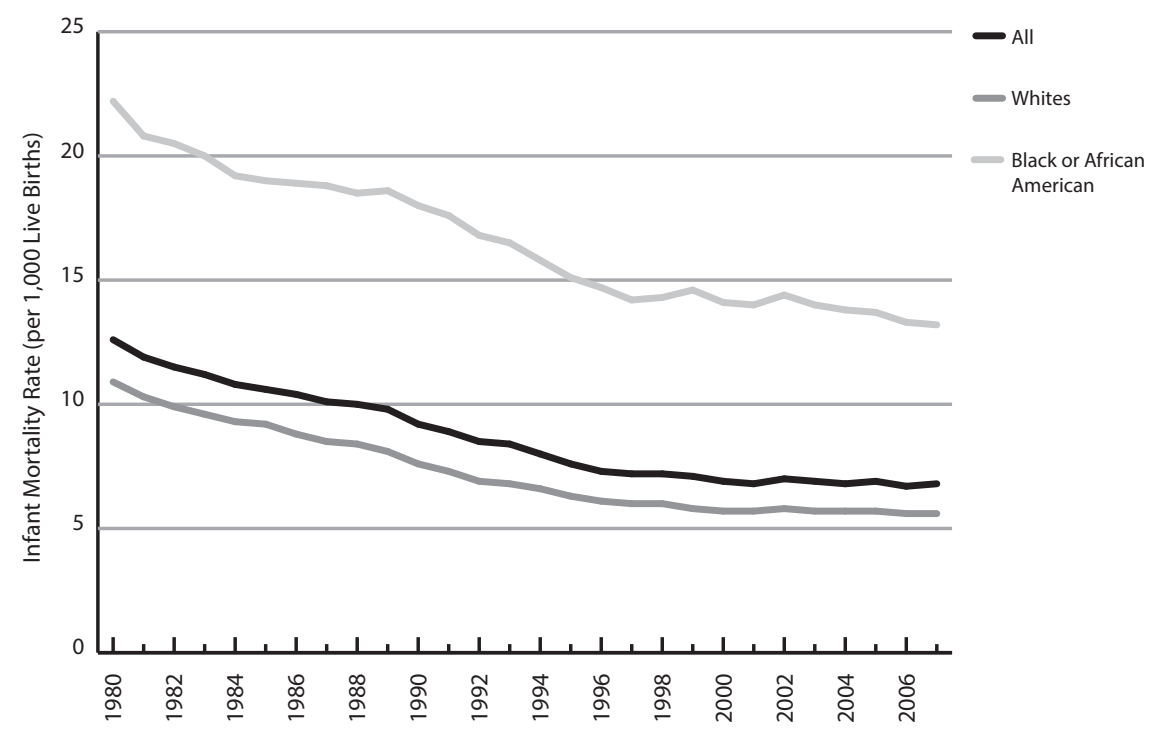

Note

Infants under age 1 .

Source

Xu et al. (2010). 


\section{Chart 25. Variation in Infant Mortality Rates, by State and Insurance Coverage, 2007}

\section{The Numbers}

Chart 35 offers a 2007 cross-sectional comparison of infant deaths per 1,000 live births in states with above and below average rates of insured persons. The two maps are mirror images of each other. The top map shows infant mortality rates in states with aboveaverage insured, and the bottom map shows infant mortality rates in states with below-average insured. Shaded states in both maps categorize states by infant mortality rates.

It is clear from the two maps that insurance coverage is not distributed equally across regions of the country. States in the South, Southwest, Rocky Mountains, and West are consistently below the state average in providing health insurance for their citizens. If higher rates of health insurance contribute to lower infant mortality statistics, we should see disproportionally more diagonally lined than black states in the top map and disproportionally more black than diagonally lined states in the bottom map. This is the case. The odds of being a low-infant-mortality (diagonally lined) state is 2.5 times greater for states with above-average insurance coverage. The odds of being a high-infantmortality (black) state among states with below-average insurance coverage is twice that among states with above-average insurance coverage. The entire south, with the exception of Alabama, exhibits above-average infant mortality and below-average insurance coverage. Texas and the Rocky Mountain states have belowaverage insurance coverage but perform relatively well on infant mortality, suggesting other factors than insurance coverage at play in affecting mortality.

\section{Commentary}

As shown in Table 35, state infant mortality rates are correlated with the percentage of uninsured $(+0.14)$, but the correlation appears relatively weak in comparison to other factors, especially income $(-0.61)$. The percentage of population living in medically underserved areas, measured by the limited supply of health professionals, also is strongly correlated with infant mortality rates. Lower incomes and fewer health professionals explain, in part, the high infant mortality rates throughout the South. Alabama, despite its above-average insurance coverage, still does not perform well on infant mortality, probably due to generally low incomes and many underserved rural areas. Conversely, states like California, Oregon, and New Mexico exhibit relatively low statewide infant mortality rates and likely offset their below-average insurance rates with higher incomes and fewer underserved areas.

States most likely to benefit from the ACA are those with below-average insurance penetration. This includes southern and Rocky Mountain states. With the spread of coverage, states in these regions should see infant mortality decline with better financial access to care. The ACA could also have a positive, indirect effect on infant mortality by attracting more physicians and nurses to previously underserved areas through higher payments for their services. 
Table 35. Factors correlated with infant mortality across states, 2007

\begin{tabular}{ll}
\hline Correlation between infant mortality and & \\
\hline Median annual household income & -0.61 \\
\hline Percent of population in underserved areas & 0.48 \\
\hline Percent of state population Hispanic & 0.28 \\
\hline Percent uninsured & 0.14 \\
\hline
\end{tabular}

\section{Sources}

Infant mortality: Matthews \&

MacDorman (2011); median income:

US Census Bureau (2007-2009);

population in underserved areas:

Health Resources and Services

Administration (2009) and US Census

Bureau (2009); percentage Hispanic

and percentage uninsured: Urban

Institute and Kaiser Commission on

Medicaid and the Uninsured (2010).

Calculations by authors.

\section{Chart 35. Variation in infant mortality rates, by state and insurance coverage, 2007}

States with Above-Average Insured (Shaded)

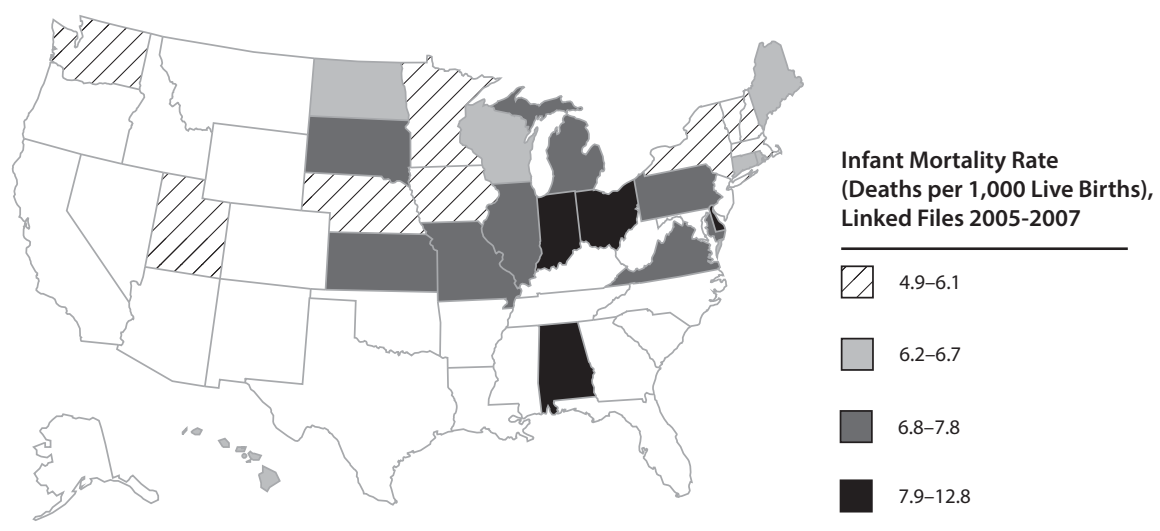

States with Below-Average Insured (Shaded)

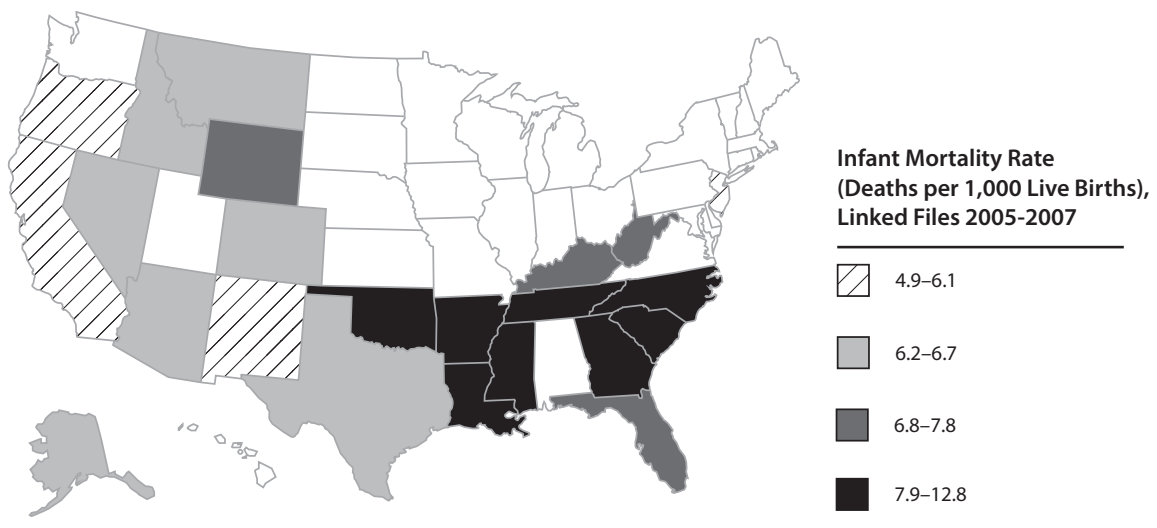

\section{Note}

In the top map, white states have below-average insurance penetration, and in the bottom map, white states have above-average insurance penetration.

\section{Sources}

Matthews \& MacDorman (2011); Urban Institute and Kaiser Commission on Medicaid and the Uninsured (2010). 


\section{Chart 26 Trends in Age-Adjusted Death Rates per 100,000 from Heart Disease and Cancer, 1981-2007}

\section{The Numbers}

With the advent of new health care advances, from penicillin to the polio vaccine to life-saving surgery, death rates have declined for what were previously top killers (i.e., infectious diseases). In 2007, the top two leading causes of death in the United States were heart disease and malignant neoplasms (cancer). Together, they accounted for 48.6 percent of all deaths (Xu et al., 2010). Chart 36 shows that age-adjusted death rates from heart disease fell by more than one-half, from 397 per 100,000 people in 1981 to only 191 per 100,000 in 2007. Age-adjusted death rates from cancer, by contrast, actually increased from 1981 through the early 1990s, before falling slightly in the 2000s. Over 26 years, the age-adjusted death rate from cancer fell from 206 per 100,000 individuals in 1981 to 178 per 100,000 in 2007 , a decline of 14 percent.

\section{Commentary}

Gains in combating life-threatening diseases have been uneven over the past 25 to 30 years, with major successes for heart disease but only limited successes with cancer-and only more recently. Spending on health care clearly does not produce the same health gains across the range of diseases. Some conditions are more amenable to interventions than others. Changing the eating and exercise habits of the population and spending substantial sums on emergency services, heart surgery, and drugs have made remarkable inroads on deaths from heart disease.

While the cost/benefit ratio for improved prevention and treatment of heart attacks is four to one (Cutler, 2005), cancer remains challenging because it is often a latent disease, going undetected until the disease has metastasized and intervention comes too late. The cohort of smokers born in the 1920s and 1930s were particularly susceptible to lung cancer in the 1980s and 1990s. The decline in the frequency of smoking in the US should pay health dividends in the decades to come without additional health care investments.

To take advantage of gains in health care from monitoring and managing heart disease, cancer, and other chronic conditions, individuals need access to primary care clinicians and prescription drugs. Access in the past has been constrained by the growth in the uninsured despite continuous expansion of the Medicare and Medicaid programs. The ACA should provide health insurance for tens of millions of uninsured Americans through the Medicaid expansion and subsidized private coverage. 
Chart 36. Trends in age-adjusted death rates per 100,000 from heart disease and cancer, 1981-2007

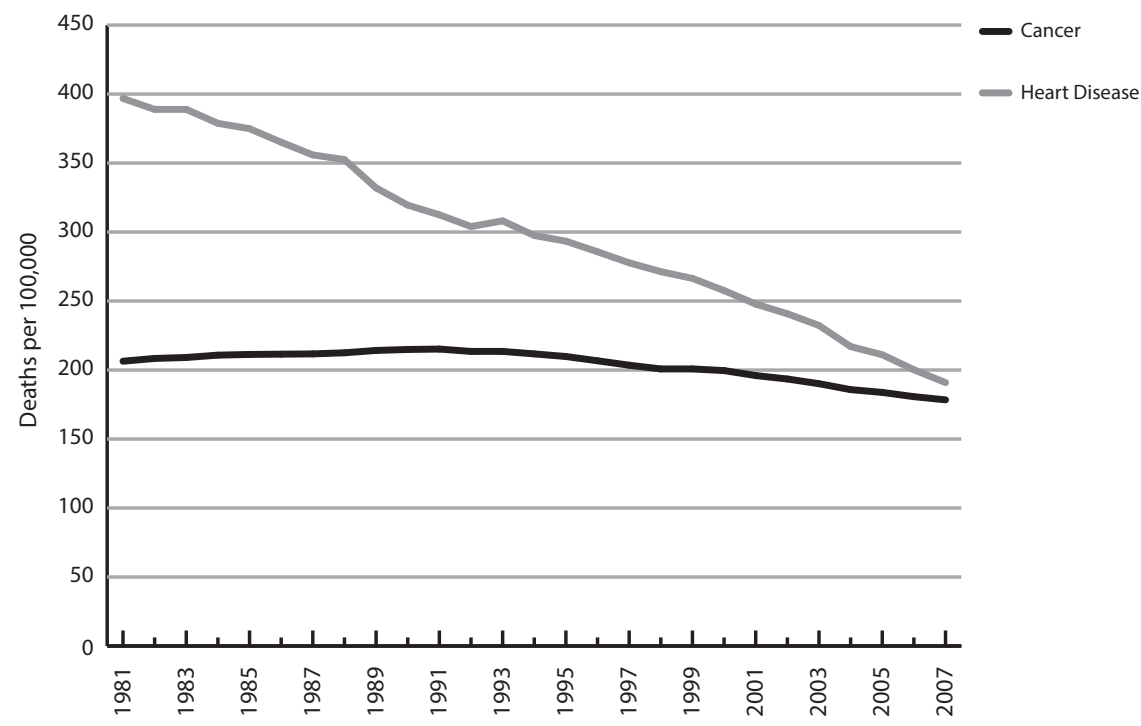

Xu et al. (2010). 


\section{Chart 37 Variation in Death Rates Due to Heart Disease, by State and Insurance Coverage, 2007}

\section{The Numbers}

Chart 37 shows death rates due to heart disease in states with above- and below-average insurance rates. Diagonally lined states have a low percentage of deaths from heart disease, and black states show a high percentage of deaths from heart disease. Under the assumption that higher rates of health insurance contribute to fewer deaths due to heart disease through better access to diagnosis and treatment, we would expect to see disproportionally more diagonally lined states in the top map and disproportionally more black states in the bottom map. However, this is not the case. There is no discernible difference in the distribution of death rates due to heart disease between the aboveand below-average insurance maps. The ratio of black to diagonally lined states in states with above-average insurance coverage (5:6) is nearly identical to the ratio in below-average states (7:8).

\section{Commentary}

Deaths due to heart disease are correlated positively with the percentage of uninsured (Table 37), but the correlation is relatively weak $(+0.17)$ in comparison with income (-0.52) and the percentage of adults who are overweight or obese $(+0.54)$. Therefore, while the ACA should improve access to diagnosis and treatment of heart disease for millions of people in the US, other nonmedical interventions, such as programs targeting obesity, have the potential to be equally, if not more, beneficial. 
Table 37. Factors correlated with heart disease across states, 2007

\begin{tabular}{ll}
\hline Correlation between the number of deaths due to heart disease per 100,000 population and & \\
\hline Percent of adults who are overweight or obese & 0.54 \\
\hline Median annual household income & -0.52 \\
\hline Percent of population in underserved areas & 0.28 \\
\hline Percent uninsured & 0.17 \\
\hline Percent of people age 65+ & 0.09 \\
\hline
\end{tabular}

\section{Chart 37. Variation in death rates due to heart disease, by state and insurance coverage, 2007}

States with Above-Average Insured (Shaded)

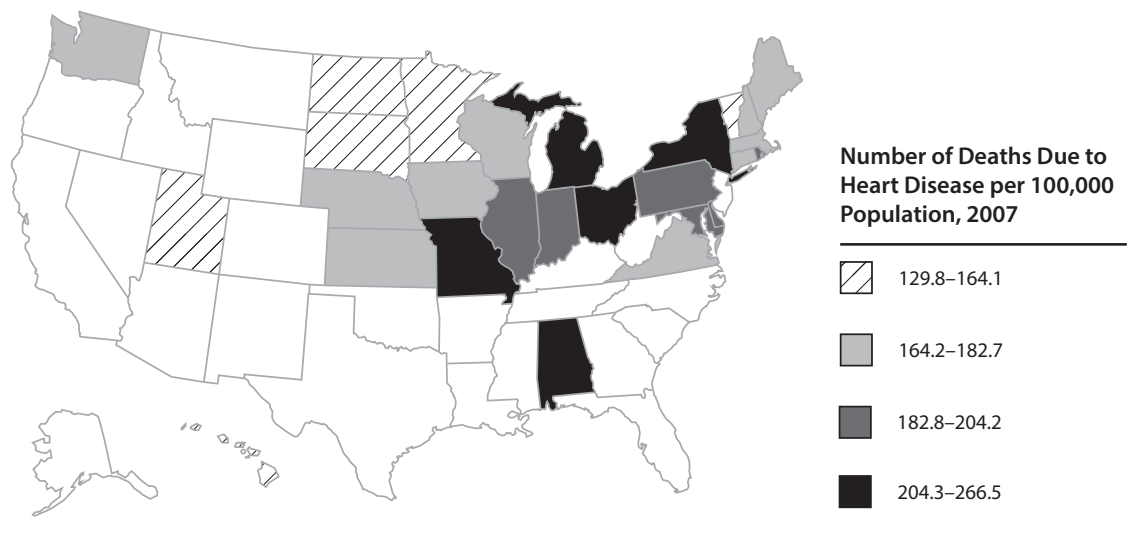

States with Below-Average Insured (Shaded)

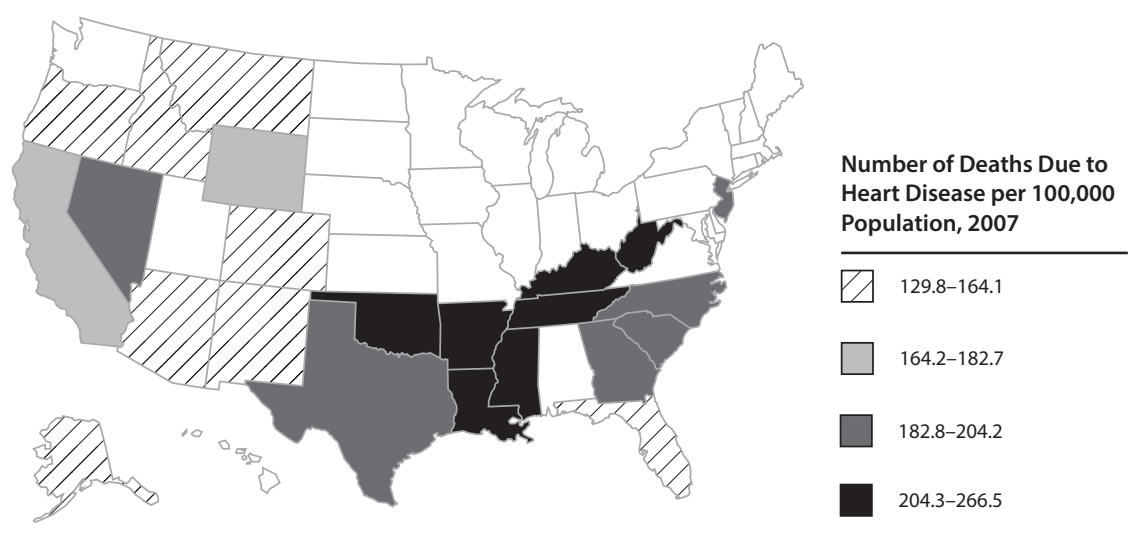

\section{Sources}

Deaths: Centers for Disease Control and Prevention (2010, May); obesity: Centers for Disease Control and Prevention (2010); median income: US Census Bureau (2007-2009); population in underserved areas: Health Resources and Services Administration (2009) and US Census Bureau (2009); percentage uninsured and percentage aged 65+: Urban Institute and Kaiser Commission on Medicaid and the Uninsured (2010). Calculations by authors.

\section{Note}

In the top map, white states have below-average insurance penetration and in the bottom map, white states have above-average insurance penetration.

\section{Sources}

Xu et al. (2010); Urban Institute and Kaiser Commission on Medicaid and the Uninsured (2010). 


\section{Chart 38 \\ Variation in Sigmoidoscopy or Colonoscopy Rates in Adults Aged 50 and Older, by State and Insurance Coverage, 2010}

\section{The Numbers}

More cost-effective health care should begin with earlier diagnosis of life-threatening disease. The maps in Chart 38 offer a cross-sectional comparison of the percentage of adults aged 50 and older who have ever had a sigmoidoscopy or colonoscopy screening exam to detect colon cancer. Black states have a much higher percentage of people who have ever had a sigmoidoscopy or colonoscopy, and diagonally lined states show a much lower percentage. Under the assumption that higher rates of health insurance make sigmoidoscopies and colonoscopies more affordable, we would expect to see disproportionally more black states in above-average insured states in the top map, and disproportionally more diagonally lined states in the bottom map. This is the case.

The odds of observing a diagonally lined, low screening state among below-average insured states is seven times the odds in above-average insured states. There were no high-screening (black) states with below-average insurance coverage, while more than half (12 of 23 including all New England states) of above-average insured states had high screening rates.

\section{Commentary}

The percentage of people in states who have ever had a sigmoidoscopy or colonoscopy is strongly correlated, negatively, with the percentage of uninsured (-0.49; Table 38). State uninsured rates are far more correlated with these preventive screenings than they were for infant mortality and heart disease.

The strong relationship between these screenings and insurance rates as well as with income likely reflects the high out-of-pocket costs that individuals often incur for screening tests-especially colonoscopy. Thus, one of the more important health benefits of the ACA is higher screening and detection rates of diseases at an earlier stage-which is particularly important for cancer. 
Table 38. Factors correlated with sigmoidoscopy or colonoscopy across states, 2010

\begin{tabular}{ll}
\hline $\begin{array}{l}\text { Correlation between percentage of adults aged } 50 \text { and older who have ever had a sigmoidoscopy or } \\
\text { colonoscopy and }\end{array}$ \\
\hline Percent uninsured & -0.49 \\
\hline Median annual household income & 0.49 \\
\hline Percent of population in underserved areas & -0.39 \\
\hline Percent of state population Hispanic & -0.12 \\
\hline Percent of people age 65+ & 0.05 \\
\hline
\end{tabular}

\section{Chart 38. Variation in sigmoidoscopy or colonoscopy rates in adults aged 50 and older, by state and insurance coverage, 2010}

States with Above-Average Insured (Shaded)

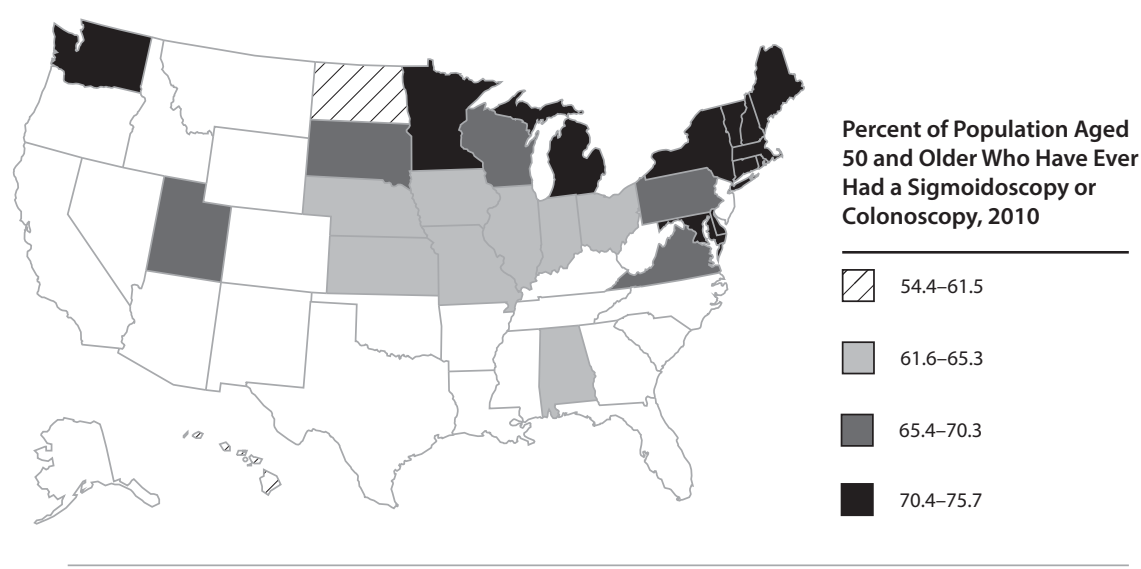

States with Below-Average Insured (Shaded)

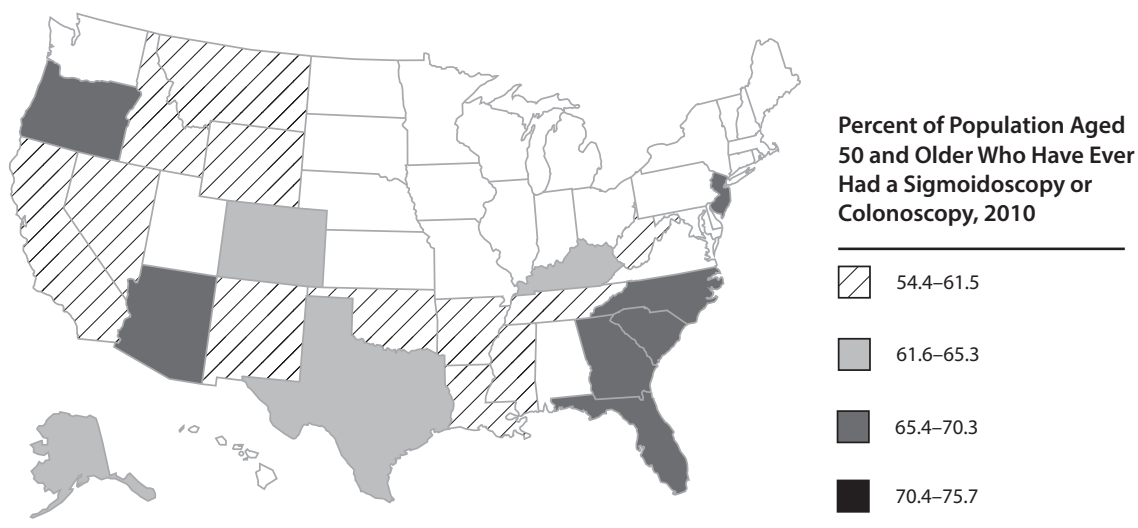

\section{Sources}

Sigmoidoscopy and colonoscopy rates: Centers for Disease Control and Prevention (2010); percentage uninsured, percentage Hispanic, and percentage aged 65+: Urban Institute and Kaiser Commission on Medicaid and the Uninsured; median income: US Census Bureau (2009); population in underserved areas: Health Resources and Services Administration (2009). Calculations by authors.

\section{Note}

In the top map, white states have below-average insurance penetration, and in the bottom map, white states have above-average insurance penetration

\section{Sources}

Centers for Disease Control and Prevention (2010); Urban Institute and Kaiser Commission on Medicaid and the Uninsured (2010). 
Chart

20 Comparison of Health Care Quality, Access, and Costs in Selected Industrialized Countries, 2009

\section{The Numbers}

Improvements in the health of Americans are well documented but have come at a high cost. Chart 39 compares the health care performance of the United States with that of six other industrialized nations for the year 2009. Per capita health care costs, adjusted for purchasing power parity, are shown in the last row. Rankings in each domain are based on numerous in-depth patient and provider surveys. For example, to measure timeliness of care, patients were surveyed on waiting times for routine appointments or elective surgery. Other questions on usual source of care and insurance coverage contributed to rankings on coordinated care and cost-related access problems.

The US health care system ranked last overall and in 5 of the 10 separate performance domains: safe care, cost-related access problems, efficiency, equity, and long, healthy, productive lives. The Netherlands ranked first, and the United Kingdom second, in overall health care system performance. Yet US health care spending per capita was nearly double the spending in the Netherlands and two and one-half times greater than in the UK. The one area in which the US ranked higher than the Netherlands was on patient-centered care, as measured by the responsiveness of physicians and other providers to individual patient needs and desires. On the other hand, the Netherlands ranked first on timeliness of care, while the US ranked only fifth, ahead of Australia and Canada.

Canada's health system was ranked just ahead of the US overall but cost almost one-half as much per capita. Canada was ranked slightly worse than the US on overall quality of care, especially on effective care, yet performed better than the US in terms of cost-related problems and long, healthy, productive lives.

\section{Commentary}

From comparisons of the US with other industrialized counties, it is clear that greater spending on health care has not produced uniformly high quality. International comparisons of health care systems based on indepth surveys belie the commonly held notion that Americans have "the best health care system in the world," a notion often based on anecdotal comparisons with nearby Canada. Closer inspection of survey results that underlie Chart 39 indicate that unequal insurance coverage and cost-related access problems are at the heart of America's low ranking on many performance categories. Without insurance coverage, the timeliness of care suffers, leading to debilitating illness and serious medical cost problems for the poor and sick. It also guarantees a low score on equity.

The US health care system has made great strides in reducing smoking and heart disease. We lead the world's fight against cancer and have developed numerous drugs extending and improving quality of life. America spends tens of billions of dollars each year on innovative research and development in the medical field. And compared with many other industrialized countries, the US health system faces greater challenges including (1) widespread poverty, (2) readily cheap, unhealthy, fast food, (3) a highly diverse immigrant population with differing cultural attitudes about using the health system, and (4) the maldistribution of critical primary care services. Improving health will require interventions targeting each of these challenges.

Nevertheless, it also seems clear that the US spends more than enough money on health care, given our overall level of health compared with other countries. The chartbook has highlighted the widespread income inequalities in both the financial burden of health care and the inefficient targeting of health resources where they are needed the most. American health care remains, for the most part, on a fee-for-service basis. Those with insurance and who can pay generally receive good, often world-class, care. But for the growing number of Americans without insurance, the timeliness and quality of their care suffer. Unless the way in which health services are paid for is changed, 
escalating costs will continue to divide the country more and more into a shrinking group of haves and an expanding group of uninsured have-nots.

The ACA addresses the problem of the uninsured in large part, but it only begins to address the cost problem. While more equal access to care unquestionably is called for in the system, the opportunity costs of unconstrained growth in utilization and prices will continue to rise over the next decade or two unless more is done to make the health system more cost-effective.

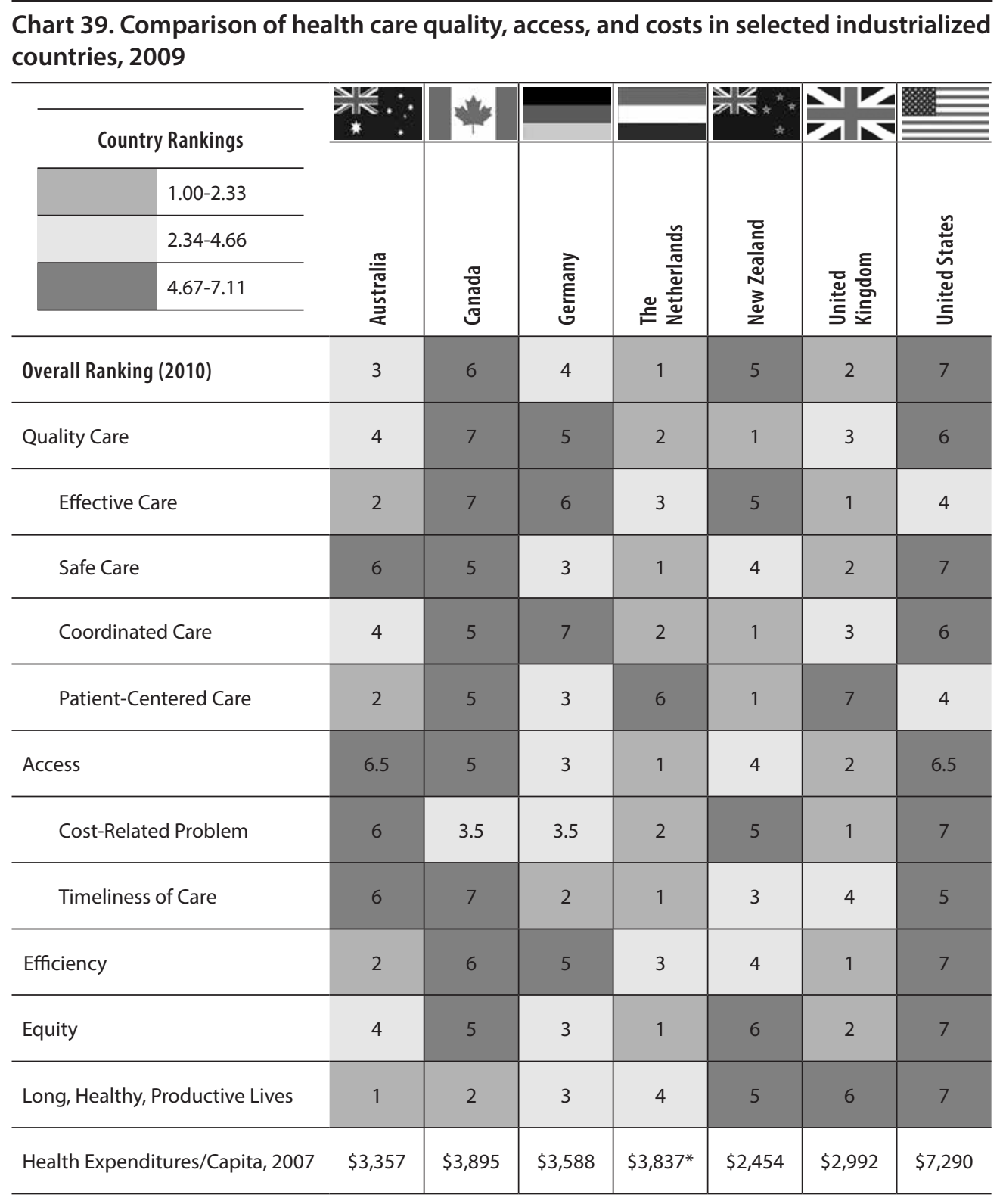

Notes

*Estimate.

Expenditures shown in \$US purchasing power parity.

Sources

Commonwealth Fund, Commission on a High Performance Health System (2009); Organisation for Economic Cooperation and Development (2009). 
Page deliberately left blank. 
References, by Chart 


\section{References}

\section{Chart 1}

Centers for Medicare \& Medicaid Services. (2012). National health expenditures by type of service and source of funds: CY 1960-2011. Retrieved from: http://www.cms. gov/Research-Statistics-Data-and-Systems/StatisticsTrends-and-Reports/NationalHealthExpendData/ NationalHealthAccountsHistorical.html

\section{Charts 2 and 3}

Centers for Medicare \& Medicaid Services. (2012). National health expenditure data. Retrieved from https://www. cms.gov/Research-Statistics-Data-and-Systems/StatisticsTrends-and-Reports/NationalHealthExpendData/

\section{Chart 4}

Centers for Medicare \& Medicaid Services. (2008). National health expenditure data. Retrieved from http://www.cms. gov/Research-Statistics-Data-and-Systems/StatisticsTrends-and-Reports/NationalHealthExpendData/

Bureau of Economic Analysis. (2009). National income and product accounts tables. Retrieved October 28, 2010, from http://www.bea.gov/iTable/index_nipa.cfm

Bureau of Labor Statistics. (2011). The Consumer Price Index: All urban consumers (CPI-U), US city average. Retrieved from: ftp://ftp.bls.gov/pub/special.requests/cpi/ cpiai.txt

\section{Chart 5}

Emanuel, E. J., \& Fuchs, V. R. (2008). Who really pays for health care? The myth of "shared responsibility." Journal of the American Medical Association, 299(9), 1057-1059.

Noah, T. (2012). The great divergence: America's growing inequality crisis and what we can do about it. New York: Bloomsbury Press.

Bureau of Economic Analysis (BEA). (2009, August 20). National income and product accounts tables. Retrieved from http://bea.gov/iTable/iTable.cfm?ReqID=9\&step=1

Bureau of Labor Statistics. (2011). Consumer Price Index: All urban consumers (CPI-U), US city average. Retrieved from: ftp://ftp.bls.gov/pub/special.requests/cpi/cpiai.txt
Centers for Medicare \& Medicaid Services (CMS). (2012). National health expenditures by type of service and source of funds: CY 1960-2011. Retrieved from: http://www.cms.gov/ResearchStatistics-Data-and-Systems/Statistics-Trendsand-Reports/NationalHealthExpendData/ NationalHealthAccountsHistorical.html

\section{Chart 6}

Barraza-Lloréns, M., \& Bertozzi, S. (2002, May). Addressing inequity in health and health care in Mexico. Health Affairs, 21(3), 47-56.

Bureau of Labor Statistics. (2010, Aug). Economic news release. Table 8. Production workers: Hourly compensation costs in U.S. dollars. Retrieved from http:// www.bls.gov/news.release/ichcc.t08.htm

\section{Chart 7}

Bureau of Labor Statistics. (2012). Labor force statistics from the Current Population Survey. Retrieved February 5, 2013, from http://www.bls.gov/cps/home.htm

\section{Chart 8}

Agency for Healthcare Research and Quality, Center for Financing, Access and Cost Trends. (2009). 2009 Medical Expenditure Panel Survey-insurance component. Retrieved from http://www.meps.ahrq.gov/mepsweb/ data_stats/summ_tables/insr/national/series_1/2009/tia2. htm

Congressional Budget Office. (2011, January 14). Small business tax credits. Health policy brief. Retrieved from http://www.healthaffairs.org/healthpolicybriefs/brief. php?brief_id=38

Kaiser Health News. (2010, June 29). Part-time workers to get help on health insurance-but not now. Retrieved from http://www.kaiserhealthnews.org/Features/InsuringYour-Health/Part-Time-Workers-Health-Insurance.aspx

McKinsey \& Company. (2011, June 20). Employer survey on US health care reform: Details regarding the survey methodology. Retrieved from http://www.mckinsey.com/ US_employer_healthcare_survey.aspx 


\section{Chart 13}

Agency for Healthcare Research and Quality. (2009). 20022009 Medical Expenditure Panel Survey-Insurance Component. Retrieved November 2010 from http://meps. ahrq.gov/mepsweb/data_stats/quick_tables.jsp

\section{Chart 14}

Bureau of Economic Analysis. (2009, Aug 20). National income and product accounts tables. Section 6 - Income and Employment by Industry. Table 6.5C. Full-time equivalent employees by industry.

\section{Chart 16}

Newhouse, J. (1993). Free for all? Lessons from the RAND health insurance experiment. Cambridge, MA: Harvard University Press.

\section{Chart 18}

Bureau of Labor Statistics. (n.d.). Consumer Expenditure Survey, consumer expenditures tables. Table 2. Income before taxes: Average annual expenditures and characteristics, Consumer Expenditure Survey, 1984. Retrieved from http://www.bls.gov/cex/1984/Standard/ Income.pdf

Bureau of Labor Statistics. (2011). Consumer expenditures in 2009. Report 1029. Table 2. Income before taxes: Average annual expenditures and characteristics, Consumer Expenditure Survey, 2009. Retrieved from http://www.bls.gov/cex/csxann09.pdf

\section{Chart 19}

Doty, M. M., Collins, S. R., Rustgi, S. D., \& Kriss, J. L. (August 2008). Seeing red: The growing burden of medical bills and debt faced by US families. Issue Brief. Commonwealth Fund Pub. 1164, Vol. 42. New York: The Commonwealth Fund.

\section{Chart 20}

Collins, S. R., Kriss, J. L., Doty, M. M., \& Rustgi, S. D. (August 2008). Losing ground: How the loss of adequate health insurance is burdening working families: Findings from the Commonwealth Fund Biennial Health Insurance Surveys, 2001-2007. New York: The Commonwealth Fund.
Himmelstein, D. U., Thorne, D., Warren, E. \& Woolhandler, S. (2009). Medical bankruptcy in the United States, 2007: Results of a national study. The American Journal of Medicine. 122: 741-746.

\section{Chart 21}

Bureau of Labor Statistics. (2012). Labor force statistics from the Current Population Survey. Retrieved February 5, 2013, from http://www.bls.gov/cps/home.htm

US Census Bureau. (2011). Current Population Survey, Annual Social and Economic Supplements. Health insurance historical tables. Table HIA-1. Health insurance coverage status and type of coverage by sex, race, and Hispanic origin: 1999 to 2009. Retrieved from http:// www.census.gov/hhes/www/hlthins/data/historical/ index.html

\section{Chart 22}

Cutler, D., \& Gruber, J. (1996). Does public insurance crowd out private insurance? Quarterly Journal of Economics, 111, 391-430.

US Census Bureau. (selected years). Current Population Survey, annual social and economic supplement. Health insurance historical tables. Table HIA-2. Health insurance coverage status and type of coverage-all persons by age and sex: 1999 to 2009, retrieved from http://www.census. gov/hhes/www/hlthins/data/historical/index.html, and Table HI-7. Health insurance coverage status and type of coverage by age: 1987 to 2005, retrieved from http://www. census.gov/hhes/www/hlthins/data/historical/orghihistt7. html

\section{Chart 23}

Helman, R., Mathew Greenwald \& Associates, \& Fronstin, P. (2004). Public attitudes on the US health care system: Findings from the Health Confidence Survey. Employee Benefit Research Institute (EBRI) Issue Brief No. 275. Washington, DC: EBRI. Retrieved from http://www.ebri. org/pdf/surveys/hcs/2004/EBRI_IB_11_2004.pdf 


\section{References (continued)}

\section{Chart 24}

Center on Budget and Policy Priorities. (2010, August 13). Top ten facts about Social Security on the program's 75th anniversary. Policy basics. Retrieved from http://www. cbpp.org/files/PolicyBasics_SocSec-TopTen.pdf

Hundley, C. (n.d.). The average 401( $k$ ) balance at retirement. Developed from Congressional Survey of Consumer Finances. E-How Money article. Retrieved from http:// www.ehow.com/info_7879709_average-401k-balanceretirement.html

Perry, M.J. (2013, Feb 2). Median-price in June highest since 2008. Retrieved from http://mjperry.blogspot. com/2012/07/median-home-price-gain-of -8-largest.html

Steuerle, E. (2011, Jul 19). Lifetime benefits and contributions: A holistic perspective on Medicare finances and reforms. Webinar: Medicare and the federal deficit. Sponsored by National Institute for Health Care Management Foundation. Washington, DC: Urban Institute. Retrieved from http://www.nihcm.org/images/ stories/071911_Webinar_Steuerle_Slides_.pdf

\section{Chart 26}

US Census Bureau. (2012). State and local governmentsrevenue and expenditures by function. Retrieved from http://www.census.gov/compendia/statab/cats/state_ local_govt_finances_employment.html

\section{Chart 27}

Phelps, C. (2003). Health Economics (3rd ed). Boston: Addison-Wesley.

\section{Chart 28}

De Lew, N. (2000). Medicare: 35 years of service. Health Care Financing Review, 22(1), 75-103.

Old-Age and Survivors Insurance and Federal Disability Insurance (OASDI) Board of Trustees. (2011). The 2011 annual report of the board of trustees of the federal
Old-Age and Survivors Insurance and Federal Disability Insurance Trust Funds (2011 OASDI Trustees Report). Retrieved from http://www.socialsecurity.gov/oact/ TR/2011/tr2011.pdf

Social Security and Medicare Boards of Trustees. (2011). A summary of the 2010 annual Social Security and Medicare trust fund reports. Retrieved from http://www. socialsecurity.gov/history/reports/trust/trustreports.html

Steuerle, C. E., \& Rennane, S. (2011). Social Security and Medicare taxes and benefits over a lifetime. Washington, DC: Urban Institute. Retrieved from http://www.urban. org/UploadedPDF/social-security-medicare-benefitsover-lifetime.pdf

US Census Bureau. (1984). Statistical abstract of the United States. Retrieved from http://www.census.gov/prod/www/ statistical_abstract.html

US Census Bureau. (2009). Statistical abstract of the United States: 2009. Retrieved from http://www.census.gov/ compendia/statab/2009/

\section{Chart 29}

Cromwell, J., Adamache, K., Ammering, C., Bartosch, W., \& Boulis, A. (1995). The equity of the Medicaid program to the poor versus taxpayers. Health Care Financing Review, 15(2), 7-30.

US Census Bureau. (2011). Number and percentage of people without health insurance coverage by state using 2- and 3-year averages: 2001-2008 and 2009-2010. Retrieved from http://www.census.gov/hhes/www/ hlthins/data/incpovhlth/2010/index.html

\section{Charts 30 and 31}

Centers for Medicare \& Medicaid Services. (2012). National health expenditures summary and GDP: Calendar years 1960-2010. Retrieved from http://www.cms.gov/ Research-Statistics-Data-and-Systems/Statistics-Trendsand-Reports/NationalHealthExpendData 


\section{Chart 33}

Centers for Medicare \& Medicaid Services. (2013). National health expenditures: Aggregate and per capita amounts, annual percent change and percent distribution: Selected calendar years 1960-2011 (Table 1). Retrieved from http://www.cms.gov/Research-StatisticsData-and-Systems/Statistics-Trends-and-Reports/ NationalHealthExpendData/Downloads/tables.pdf

Cutler, D., Rosen, A., \& Vijan, S. (2006). The value of medical spending in the United States, 1960-2000. New England Journal of Medicine, 355(9), 920-927.

Xu, J. Q., Kochanek, K. D., Murphy, S. L., \& Tejada-Vera, B. (2010). Deaths: Final data for 2007, Table 8. National Vital Statistics Reports, 58(19). Hyattsville, MD: Centers for Disease Control and Prevention, National Center for Health Statistics. Retrieved from http://www.cdc.gov/ nchs/data/nvsr/nvsr58/nvsr58_19.pdf

\section{Chart 34}

Cutler, D. (2005). Your money or your life. Strong medicine for America's health care system. New York: Oxford University Press.

CIA. (2012). The world factbook: Country comparison: Infant mortality rate. Retrieved from https://www.cia.gov/ library/publications/the-world-factbook/

Kaiser State Health Facts (n.d.). Infant mortality rate. Retrieved from http://www.statehealthfacts.org/index.jsp

Xu, J. Q., Kochanek, K. D., Murphy, S. L., \& Tejada-Vera, B. (2010). Deaths: Final data for 2007, Table 30. National Vital Statistics Reports, 58(19). Hyattsville, MD: National Center for Health Statistics. Retrieved from http://www. cdc.gov/nchs/data/nvsr/nvsr58/nvsr58_19.pdf

\section{Chart 35}

Health Resources and Services Administration. (2009, April). Special data request, 2008 population data from Annual Population Estimates by State, July 1, 2008.
Matthews, T. J., \& MacDorman, M. F. (2011). Infant mortality statistics from the 2007 period linked birth/ infant death data set. National Vital Statistics Report, 59(6). Hyattsville, MD: National Center for Health Statistics. Retrieved from http://www.cdc.gov/nchs/data/ nvsr/nvsr59/nvsr59_06.pdf

Urban Institute and Kaiser Commission on Medicaid and the Uninsured. (2010). Estimates based on the Census Bureau's March 2009 and 2010 Current Population Survey (CPS: Annual Social and Economic Supplements).

US Census Bureau. (2007-2009). Current Population Survey, 2007 to 2009 annual social and economic supplements. Three-year-average median household income by state: 2007-2009 and Two-year-average median household income by state: 2008 to 2009, Retrieved from http:// www.censUS.gov/hhes/www/income/data/statemedian/ index.html

US Census Bureau. (2009). Population estimates: Vintage 2008: State tables. Retrieved from http://www.census.gov/ popest/data/historical/2000s/vintage_2008/state.html

\section{Chart 36}

Xu, J. Q., Kochanek, K. D., Murphy, S. L., \& Tejada-Vera, B. (2010). Deaths: Final data for 2007. National Vital Statistics Reports, 58(19). Hyattsville, MD: National Center for Health Statistics. Accessed March 3, 2012. Retrieved from http://www.cdc.gov/nchs/data/nvsr/ nvsr58/nvsr58_19.pdf

Cutler, D. (2005). Your money or your life. Strong medicine for America's health care system. New York: Oxford University Press.

\section{Chart 37}

Centers for Disease Control and Prevention. (2010). Behavioral Risk Factor Surveillance System survey data. Retrieved from http://apps.nccd.cdc.gov/brfss/

Health Resources and Services Administration. (2009, April). Special data request, 2008 population data from Annual Population Estimates by State, July 1, 2008. 


\section{R References (continued)}

Urban Institute and Kaiser Commission on Medicaid and the Uninsured. (2010). Estimates based on the Census Bureau's March 2009 and 2010 Current Population Survey (CPS: Annual Social and Economic Supplements).

US Census Bureau. (2007-2009). Current Population Survey, 2007 to 2009 annual social and economic supplements. Three-year-average median household income by state: 2007-2009 and Two-year-average median household income by state: 2008 to 2009. Retrieved from http:// www.censUS.gov/hhes/www/income/data/statemedian/ index.html

US Census Bureau. (2009). Population estimates: Vintage 2008: State tables. Retrieved from http://www.census.gov/ popest/data/historical/2000s/vintage_2008/state.html

Xu, J. Q., Kochanek, K. D., Murphy, S. L., \& Tejada-Vera, B. (2010). Deaths: Final data for 2007. National Vital Statistics Reports, 58(19). Hyattsville, MD: Centers for Disease Control and Prevention, National Center for Health Statistics. Retrieved from http://www.cdc.gov/ nchs/data/nvsr/nvsr58/nvsr58_19.pdf

\section{Chart 38}

Centers for Disease Control and Prevention. (2010). The Behavioral Risk Factor Surveillance System, prevalence and trends data. Retrieved from http://apps.nccd.cdc.gov/ brfss/

Health Resources and Services Administration. (2009, April). Special data request, 2008 population data from Annual Population Estimates by State, July 1, 2008.

US Census Bureau. (2009). Current Population Survey, 2007 to 2009 annual social and economic supplements. Threeyear-average median household income by state: 2007 2009 and Two-year-average median household income by state: 2008 to 2009 , Retrieved from http://www.census. gov/hhes/www/income/data/statemedian/index.html

Urban Institute and Kaiser Commission on Medicaid and the Uninsured. (2010). Estimates based on the Census Bureau's March 2009 and 2010 Current Population Survey (CPS: Annual Social and Economic Supplements).

\section{Chart 39}

Commonwealth Fund, Commission on a High Performance Health System. (2009). National scorecard. Retrieved from http://www.commonwealthfund.org/ProgramAreas/Health-Reform-Policy/Commission-on-a-HighPerformance-Health-System.aspx

Organisation for Economic Cooperation and Development. (2009). Health data, 2009. Paris: OECD. 
Page deliberately left blank. 


\section{RTI Press}

